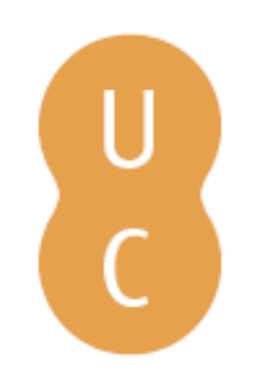

\title{
pompalina
}

O percurso de Dido, rainha de Cartago, na literatura latina

Autor(es): $\quad$ Pinheiro, Cristina Santos

Publicado por: Centro de Estudos Clássicos e Humanísticos; Imprensa da Universidade

URL

persistente: URI:http://hdl.handle.net/10316.2/2349

DOI: $\quad$ DOI:http://dx.doi.org/10.14195/978-989-8281-35-7

Accessed : $\quad$ 26-Apr-2023 13:54:16

A navegação consulta e descarregamento dos títulos inseridos nas Bibliotecas Digitais UC Digitalis, UC Pombalina e UC Impactum, pressupõem a aceitação plena e sem reservas dos Termos e Condições de Uso destas Bibliotecas Digitais, disponíveis em https://digitalis.uc.pt/pt-pt/termos.

Conforme exposto nos referidos Termos e Condições de Uso, o descarregamento de títulos de acesso restrito requer uma licença válida de autorização devendo o utilizador aceder ao(s) documento(s) a partir de um endereço de IP da instituição detentora da supramencionada licença.

Ao utilizador é apenas permitido o descarregamento para uso pessoal, pelo que o emprego do(s) título(s) descarregado(s) para outro fim, designadamente comercial, carece de autorização do respetivo autor ou editor da obra.

Na medida em que todas as obras da UC Digitalis se encontram protegidas pelo Código do Direito de Autor e Direitos Conexos e demais legislação aplicável, toda a cópia, parcial ou total, deste documento, nos casos em que é legalmente admitida, deverá conter ou fazer-se acompanhar por este aviso.

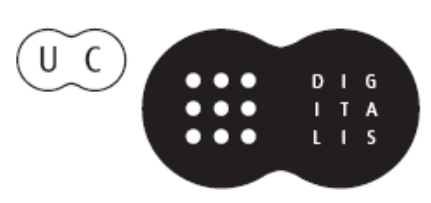




\section{o percurso de Dido, rainha de Cartago, na literatura latina}

Cristina Santos Pinheiro 


\section{Cristina Santos Pinheiro}

(Universidade da Madeira)

\section{O percurso de Dido, rainha de Cartago, na Literatura Latina}


Todos os volumes desta série são sujeitos a arbitragem científica independente.

Autor: Cristina Santos Pinheiro

Título: O percurso de Dido, rainha de Cartago, na Literatura Latina

Editor: Centro de Estudos Clássicos e Humanísticos

IMPRENSA DA UNIVERSIDADE DE COIMBRA

Coordenador Científico do Plano de Edição: Maria do Céu Fialho

Conselho Editorial: José Ribeiro Ferreira, Maria de Fátima Silva,

Francisco de Oliveira, Nair Castro Soares

Director técnico da Colecção: Delfim F. LeÃo

Concepçấo gráfica e paginação: Elisabete CaÇão, Nelson Ferreira,

RODOLFo Lopes

Obra REALIZADa no ÂMbito Das aCtividades da UI\&D

Centro de Estudos Clássicos e Humanísticos

UNIVERSIDADE DE CoImbra

FaCUldade de Letras

TEL.: 239859981 | FAX: 239836733

3000-447 CoImbra

ISBN: 978-989-8281-34-0

ISBN DigITAL: 978-989-8281-35-7

Depósito Legal: $311733 / 10$

Obra Publicada com o Apoio de:

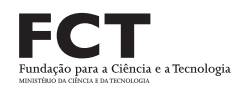

POCI $/ 2010$

(C) Imprensa da Universidade DE CoImbra

(c) Classica Digitalia Vniversitatis Conimbrigensis

(C) Centro de Estudos Clássicos e Humanísticos da Universidade de Coimbra

(C) Centro de Estudos Clássicos da Universidade de Lisboa

Reservados todos os direitos. Nos termos legais fica expressamente proibida a reprodução total ou parcial por qualquer meio, em papel ou em edição electrónica, sem autorização expressa dos titulares dos direitos. É desde já excepcionada a utilização em circuitos académicos fechados para apoio a leccionação ou extensão cultural por via de e-learning. 


\section{ÍNDICE}

Nota PrÉVIa

$\begin{array}{ll}\text { INTRODUÇÃO } & 11\end{array}$

$\begin{array}{ll}\text { NOTAS } & 13\end{array}$

$\begin{array}{ll}\text { Capítulo I - Virgílio, CRIAdor de Dido } & 15\end{array}$

Capítulo II - Dido e Ovídio: desfazendo ambiguidades 51

Anexo: Epístola escrita por Dido a Eneias $\quad 77$

Capítulo III -Reelaboração épica: Virgílo vs. Ovídio nos Punicorum libri de Sílio Itálico 83

Capítulo IV - A resposta aos mestres: a versão da “Casta Dido” 103

$\begin{array}{ll}\text { ANEXo } & 115\end{array}$

Capítulo V - Entre Virgílio e Ovídio: a Epistula Didonis aD AENEAM 121

Anexo: Antologia latina - Epístola escrita POR Dido a ENEIAS 135

Anexos

Anexo A: Fazer ReViver Dido 143

Anexo B: Dido em Jacqueline Kelen:

A BELEZA DO AMOR E O AMOR DA BELEZA (UM EXEMPLO DE ACTUALIZAÇÃo) 163

$\begin{array}{lr}\text { ConclusÃo } & 179\end{array}$

$\begin{array}{ll}\text { Bibliografia } & 181\end{array}$ 
À memória de António Manuel Coelho Antunes 


\section{Nota Prévia}

Este volume é o resultado do trabalho de investigação realizado com vista à apresentação de Provas de Aptidáo Pedagógica e Capacidade Científica, na Universidade da Madeira, em 2001, no âmbito da disciplina de Literatura Latina. Beneficiou da arguição sábia do Professor Doutor José António Segurado e Campos, que enriqueceu este trabalho com sugestôes valiosas posteriormente nele integradas e da orientação da Professora Doutora Maria Cristina Pimentel.

A definição do tema do Trabalho de Síntese, no âmbito da realizaçăo de Provas de Aptidáo Pedagógica e Capacidade Científica, inclinou-se com naturalidade para dois autores que considero dos mais notáveis da literatura ocidental: Virgílio ${ }^{1}$ e Ovídio. Encontrar um denominador comum, que permitisse equacionar a obra de ambos, foi ainda mais natural, já que, tendo conhecimento prévio da Eneida, a leitura da Heróide 7 de Ovídio se nos revelou uma agradável surpresa pelo cunho humanizante que imprime em Dido. As questôes que a personagem coloca acerca da diversidade da natureza humana têm sido preocupaçáo assídua da Humanidade, embrenhados que estamos em formular uma equação, em definir um mapa ou um guia para cada ser humano. Desde o ano em que esta síntese foi defendida, os estudos sobre as epístolas ovidianas assistiram a um incremento notável, incremento de que o nosso texto não pôde beneficiar. Podemos dizer algo semelhante em relação à Eneida, já que a bibliografia virgiliana se enriquece a cada dia que passa. Ainda

${ }^{1}$ Por indicação do Conselho Editorial dos Classica Digitalia, utilizamos em todo o texto a forma "Virgílio" e "virgiliano" ou "virgiliana", em vez de "Vergílio", "vergiliano" ou "vergiliana", que preferimos. 
assim, procedemos à actualização da bibliografia no final do volume, de modo a incluir algumas das mais recentes obras de referência relativas tanto à obra de Virgílio como às Epistulae de Ovídio, mas com a plena consciência da impossibilidade de ter uma bibliografia completa sobre qualquer um dos dois autores. Os passos em tradução são da nossa autoria, salvo indicação em contrário.

Este trabalho é fruto de uma longa teia de relaçóes humanas sem a qual não teria sido possível. Devo uma palavra muito especial de reconhecimento ao Professor Segurado e Campos pela simpatia e rigor com que arguiu as minhas provas, transformando a sua defesa numa conversa amena e instrutiva. À Professora Doutora Cristina Pimentel endereço o meu mais sincero tributo de agradecimento e admiração pela forma como orientou este trabalho com rigor e dedicação inesgotáveis e como, desde os tempos da minha licenciatura, intensificou o meu gosto pela Literatura Latina, porque sabe como poucos reconhecer a actualidade dos Estudos Clássicos e lhes confere o interesse imorredouro que de facto têm, insuflando neles a vida e a dinâmica que tantas vezes lhes são negadas. Ao Professor Doutor Arnaldo Espírito Santo, pela simpatia e pelo estímulo sempre presentes, expresso o meu respeito e reconhecimento. Agradeço ainda à Secção Autónoma de Estudos Clássicos e Humanísticos da Universidade da Madeira a boa vontade com que acolheu a realizaçáo deste trabalho.

À Mariana, que ainda não existia quando este texto foi escrito, uma palavra de carinho pela forma como enriqueceu a minha vida. Ao Joaquim, companheiro incansável de todas as horas, um profundo e sincero obrigado pelo apoio e empenho permanentes. Aos meus pais e ao meu irmão a minha gratidão pelo afecto incondicional que me acompanha desde que tenho memória. Ao meu tio, a quem dedico este trabalho, um até sempre e o meu agradecimento pela motivação inesgotável e pela confiança que depositou em mim, e porque tantas palavras ficaram por dizer...

Funchal, Fevereiro de 2010. 


\section{INTRODUÇÃo}

Qualquer tentativa de abranger a essência de uma personagem como Dido parece, à primeira vista, um percurso demasiado trilhado e previsível. A complexidade da personagem e o fascínio que tem suscitado ao longo dos séculos actua, todavia, como um atractivo a que se torna impossível resistir. A busca de uma definição absoluta e unívoca de Dido é um ideal inalcançável, uma vez que o seu carácter arredio e misterioso obsta a uma análise definitiva. Por esta razáo, o acervo bibliográfico que explora o assunto enriquece-se a cada ano que passa com interpretações que se contradizem e complementam.

Os livros 1 a 4 e 6 da Eneida de Virgílio constituem a versão mais célebre e influente da história de Dido, ainda que Névio, autor do século III a II a. C., pareça ter antecipado alguns elementos retomados na epopeia virgiliana. $\mathrm{O}$ estado fragmentário de Bellum Poenicum não permite, todavia, tirar conclusóes precisas acerca da caracterizaçáo de Dido e da forma como a sua história seria explorada no contexto das hostilidades entre Romanos e Cartagineses. Parece, no entanto, certo que Eneias se encontrava com a rainha de Cartago e que, perante ela, relatava a queda de Tróia:

Blande et docte percontat Aeneas quo pacto Troiam urbem liquerit. (Frg. 23 Morel)

Terna e sabiamente conta Eneias de que modo deixou para trás a cidade de Tróia.

Este fragmento, só por si, não nos permite assegurar que Eneias fale perante Dido. Todavia, de acordo com Albrecht 1999: 45-50, é provável que Névio tenha recorrido à presença da rainha e ao encontro infeliz com Eneias para justificar a génese das guerras púnicas. Assim se explicaria a maldição que na Eneida Dido lança sobre os futuros descendentes de Eneias. Horsfall 1990: 139-140, 143-144, pelo contrário, mostra-se relutante na aceitação da hipótese de que Névio tenha apresentado uma relação 
amorosa entre Dido e Eneias e justifica os elementos negativos da caracterização de Dido na epopeia virgiliana com a desconfiança que a tradição romana sentia perante os Cartagineses e que estaria já presente no Bellum Poenicum de Névio. Deste modo, a descrição da rainha como um ser nocivo e pouco fiável traria à memória dos leitores de Virgílio os sentimentos anti-Cartago dos Romanos, veiculados na obra de Névio ${ }^{1}$.

Qualquer que tenha sido a contribuição deste autor para a caracterização de Dido, foi a versão de Virgílio que mais influenciou o público romano e legou à posteridade o ponto de partida de tantas obras literárias. A grande maioria das abordagens posteriores constrói-se como resposta à epopeia virgiliana que, por este motivo, tomámos como base para a análise posterior. Sem ter pretensóes de exaustão que impossibilitariam a realização deste trabalho, a investigação incidiu na caracterização de Dido em cada um dos textos analisados e na relaçáo desta com as versóes anteriores. Pela mesma razão, omitimos referências pontuais a Dido, optando por pesquisar textos que, de forma mais sistemática ou apreciável, contribuam para a definição da personagem.

Analisamos em anexo, de forma sucinta, a pervivência de Dido em alguns textos da literatura ocidental e numa das últimas obras que reescreveu o episódio do seu encontro com Eneias, sem outro propósito que náo o de mostrar que a personagem ultrapassou amplamente as fronteiras da literatura latina, porque, de uma forma ou de outra, acompanha o evoluir da sensibilidade Ocidental.

${ }^{1}$ Para uma síntese das interpretaçóes da questão da presença de Dido no Bellum Poenicum, cf. Albrecht 1999: 49-50. 


\section{Notas}

As ediçóes dos textos utilizados estão identificadas no Ponto 1. da Bibliografia. Para todos os textos cuja edição não esteja aí devidamente indicada, seguimos a edição do Packard Humanities Institute, no caso dos textos latinos, e a do Thesaurus Linguae Graecae para os textos gregos.

Em todas as ediçôes, substituímos $-v$ por $-u$.

Utilizamos para os títulos das obras latinas as abreviaturas do Oxford Latin Dictionary e para as obras gregas, as do GreekEnglish Lexicon. 
Capítulo I

Virgílio, CRIADOR DE Dido 
Tentar definir a essência de Dido na Eneida só encontra uma base sustentável na fascinante complexidade da caracterizaçáo da personagem. De facto, Dido é uma das individualidades mais densas da obra e desta densidade nascem interpretaçóes múltiplas que, longe de se anularem, se complementam, num processo inesgotável que se insere na interpretação (igualmente inesgotável) da épica virgiliana.

A história da rainha de Cartago desenvolve-se nos livros 1 a 4 da obra, com pesos diferentes em cada um, e termina com uma breve aparição no livro $6 .{ }^{1}$

Cartago, colónia da Fenícia, é descrita como a cidade predilecta de Juno, deusa inimiga dos Troianos (1.1ss.), ressentida desde o rapto de Ganimedes e o julgamento de Páris. Aumenta o rancor da deusa contra os Troianos o oráculo que previa que do sangue dos Teucros nasceria um povo que governaria um vasto império e que, notável na guerra (1.21), haveria de destruir Cartago. A caracterização dos Cartagineses, longe de ser completa, limita-se a referir a sua origem (1.12), a situação geográfica de Cartago relativamente à Itália (1.13-14), o seu poder económico e a aptidão do povo tírio para a guerra (1.14). Nem Juno, quando se lamenta de os seus desejos não receberem por parte de Júpiter o acolhimento conveniente, refere os Cartagineses, nem Júpiter os menciona quando desenrola perante Vénus o destino dos Troianos. Apenas quando termina e envia Mercúrio à Líbia para que Cartago não feche as portas a Eneias e aos seus companheiros, se volta a falar de Dido e do seu povo. E, por intervenção divina (1.303), os Cartagineses despojam-se dos seus "espíritos violentos" (1.302-3) e a disposição da rainha para com os Troianos torna-se "benigna" (1.303-4). Dido é alvo desta intervenção para que,

${ }^{1}$ Apesar de surgir pela primeira vez no livro 1, nos livros 2 e 3 adivinhamos apenas a sua presença, uma vez que Eneias narra perante Dido a queda de Tróia. O livro 4 é, por excelência, o episódio dos amores de Dido e Eneias, desde o despontar da paixão na rainha à partida de Eneias e ao suicídio de Dido. No livro 4, a sombra de Dido aparece a Eneias nos Infernos, sendo este o último encontro de ambos. 
"desconhecedora do destino" (1.299), não se oponha à vontade dos deuses. Deste modo, com a manipulaçáo da natureza dos Cartagineses e da sua rainha está preparada a chegada de Eneias e dos seus companheiros.

Depois de terem enfrentado a tempestade desencadeada por Juno para os afastar da Itália, desembarcam na Líbia. Julgando perdidos alguns dos seus companheiros, Eneias sai do acampamento para explorar as redondezas. Nesta caminhada, encontra Vénus disfarçada como uma jovem caçadora: armada de arco e aljava $(1.318 ; 1.336)$, com os cabelos soltos (1.319), joelhos descobertos (1.320) e calçada com coturnos cor de púrpura (1.337). A forma como a deusa se apresenta perante Eneias, como uma jovem ${ }^{2}$, antecipa o contexto erótico do encontro daquele com Dido. Afirma Oliensis 1997: 306, a este propósito: "The point is that Venus presents herself to her son in the guise of a marriageable girl, offering him a kind of preview of Dido."

A razão do disfarce parece obscura. Se o objectivo da deusa era não ser reconhecida pelo filho, o disfarce foi um fracasso, uma vez que este imediatamente se dá conta de que não está na presença de um ser mortal (1.327-9) e, no momento em que Vénus se prepara para partir, Eneias reconhece a mãe, acusando-a, entáo, de ser cruel para com o seu próprio filho (1.407-9).

Segundo Harrison 1988: 201 e Pobjoy 1998: 43, Vénus aparece disfarçada para náo ser reconhecida por Juno, uma vez que se encontra em território protegido por esta ${ }^{3}$. Hipótese a ter em conta, se tivermos em atenção o facto de, em outros encontros com Eneias (2.589ss.; 8.608ss.), Vénus não usar qualquer tipo de disfarce. Parece, então, que, em Tróia e na terra prometida pelo destino, não há necessidade de artifícios. Assim, ao aparecer disfarçada a Eneias, será intenção da deusa mostrar-lhe que se encontra em território inimigo ou, pelo menos, que não pode confiar nos seus anfitrióes, ainda que a história do passado de Dido (bem como a representação da queda de Tróia no templo de Juno) pareça ser uma forma de atenuar a angústia dos Troianos.

De acordo com Hardie 1997: 322 e com os autores citados, ao apresentar Vénus calçada com coturno (1.337), à maneira dos actores trágicos, Virgílio realça o carácter trágico que caracteriza o episódio da paixão de Dido por Eneias. Quando este diz a Vénus

${ }^{2}$ Juventude enfatizada pela repetição de uirginis em 1.314 .

${ }^{3}$ É também recorrendo ao disfarce, assumindo a imagem de Ascânio, que Cupido instila em Dido o "fogo oculto" da paixão (1.688). 
que ela deve ser um dos imortais (1.327-9), talvez a própria Diana ou uma ninfa, a deusa faz questáo de explicar o uso dos coturnos (e da aljava) como um costume das jovens fenícias. No entanto, já que o coturno era o calçado utilizado também pelos caçadores, não seria de estranhar numa jovem que, supostamente, caça com as irmãs.

Ao descrever a Eneias o passado de Dido, Vénus, calçada com coturnos em vez de sandálias, parece proferir o prólogo da tragédia que vai resultar do encontro de ambos, já que apresenta os antecedentes da vida da rainha, o percurso que a conduziu até à fundação de Cartago (Harrison 1988: 207ss.). A história do exílio forçado de Dido apresenta algumas semelhanças com o passado de Eneias: ambos se viram coagidos a abandonar a pátria, ambos assumiram o estatuto de líder por força das circunstâncias, ambos perderam entes queridos, um e outro viajaram pelo mar em busca de um refúgio. Devemos referir ainda a fundação de uma cidade em terras estrangeiras, facto que para Dido é já uma realidade e para Eneias ainda um almejo. As afinidades do passado de ambos são um modo de preparar Eneias para o encontro com a rainha e de despertar o interesse do Troiano por um ser assim semelhante a si próprio. No entanto, lêem-se nas entrelinhas algumas notas menos abonatórias do carácter de Dido e dos Cartagineses (Cairns 1989: 42-3, 99). A inimizade entre estes e os povos vizinhos devia ter sido interpretada por Eneias como um mau presságio, como sinal de que não se encontrava perante um povo pacífico. A acrescentar ao carácter hostil dos Cartagineses, os antecedentes familiares de Dido (discórdia, ambição, crime...) não auguram um bom desfecho para a relação entre os dois povos. O exílio de Dido foi motivado pela ambição desmedida do seu próprio irmáo e por um crime hediondo por ele cometido. É sobre estes princípios pouco louváveis que é fundada a cidade de Cartago. Assim, tudo é ambíguo no encontro de Eneias com a sua mãe: das palavras à aparência física, tudo se presta a leituras mais complexas do que poderia parecer numa primeira análise.

É o que acontece, como referido, com o disfarce de Vénus. Além de, pela referência ao cothurnus e pela narração do passado de Dido, Vénus assumir a função de uma personagem trágica, a caracterização da deusa com atributos de Diana produz uma ambiguidade flagrante, se não paradoxal. Com a aparência de uma jovem caçadora, Vénus reveste-se de características que não são suas. $\mathrm{Na}$ descrição da deusa estão presentes dois factores que 
acentuam a identificação de Vénus com entidades que merecem alguma reflexão. Vénus aparece "transportando armas de uma jovem espartana” (1.315-6) e é comparada a Harpálice, figura mitológica oriunda da Trácia, correndo pelas margens do rio Hebro com os seus cavalos velozes (1.316-7). ${ }^{4}$ Não pode ser casual o facto de tanto as mulheres de Esparta como as da Trácia serem exemplos de sistemas em que a educação feminina ultrapassava a preparação para a vida familiar e para a economia da casa. As mulheres de Esparta recebiam uma educação que incluía exercícios físicos e preparação musical e artística, além de, segundo algumas fontes, exercerem maior influência sobre os maridos e os filhos do que seria desejável ${ }^{5}$. As mulheres da Trácia tinham também uma vida particularmente activa ${ }^{6}$.

Podemos, assim, concluir que Vénus surge deliberada e enfaticamente associada a padróes atípicos de educação feminina que valorizam a intervenção activa das mulheres. E é neste contexto que devemos entender o relato que Vénus faz das façanhas de Dido. Disfarçada e descrevendo-lhe o passado audacioso da rainha, Vénus introduz Eneias numa comunidade em que é uma mulher quem assume a liderança. Forçada pelas vicissitudes do seu passado, Dido evoluiu do estatuto de esposa devota (1.344-6) para a posição de monarca, anormal para a sua condição de mulher ${ }^{7}$.

Ao chegar a Cartago, Eneias entra no templo de Juno e fica surpreendido com a representação de cenas da guerra de Tróia. $\mathrm{O}$ que Eneias interpreta como a veneração da calamidade que os Troianos sofreram, levanta, no entanto, algumas questóes ${ }^{8}$. Eneias

${ }^{4}$ Filha do rei trácio Harpálico que a educou para lhe suceder, uma vez que não tinha filhos homens. A jovem tornou-se hábil no manejo das armas e, quando ambos foram expulsos da cidade, refugiaram-se nos bosques, vivendo da caça e da pilhagem. A celeridade da jovem permitia-lhe roubar sem nunca ser apanhada, até que um dia foi capturada numa armadilha para animais selvagens. Cf. Grimal 1982: ad voc. e Sérvio, $A$. 1.316ss..

${ }^{5}$ Cf. Pl. Lg. 7.804e; Arist. Pol. 1269b12; Plu. Lyc. 14.

${ }^{6}$ Cf. Pl. Lg. 7.804e.

${ }^{7}$ De acordo com Hardie 1997: 321-2, Dido aceita esta mudança de estatuto até à chegada de Eneias e dos Troianos. Depois, gera-se nela a confusão.

${ }^{8}$ Pöschl 1962: 70 afirma que nas imagens do templo Eneias reconhece a humanitas de Dido. Suzuki 1989: 106-7 explica a interpretação favorável de Eneias pela obsessão deste pelo seu próprio passado. Hexter 1992: 355ss. considera que Eneias interpreta erroneamente as imagens: "To infer from such decorations in a temple dedicated to Juno that her devotees would be kindly to Juno's enemies is a monumentally stupid inference." (355) Da mesma opiniáo: 
vê nas imagens um sinal de que pode confiar nos Cartagineses, uma prova de que Dido sente compaixão pelo destino de Tróia. Esquece, todavia, que essas mesmas imagens retratam a vitória dos Aqueus sobre os Troianos e que o templo em que se encontram foi dedicado por Dido à divindade que é a mais forte opositora à sua missão ${ }^{9}$. Assim, ao invés de aliviar a dor de Eneias, a representação pictórica da derrota dos Troianos deveria suscitar nele algumas desconfianças, já que o objectivo destas pode ser a celebração da destruição de Tróia e a sua consagração a Juno. Eneias continua, assim, a "ler" de forma favorável as várias pistas que vão sendo semeadas no seu percurso em direcção à rainha.

Eneias vai observando nas portas do templo representaçóes de episódios da guerra de Tróia, numa viagem dolorosa ao seu próprio passado. $\mathrm{Na}$ sequência destas imagens, assume especial importância a descrição de Pentesileia, por anteceder a entrada em cena de Dido ${ }^{10}$.

Pentesileia é descrita não no momento da sua morte às mãos de Aquiles, que se apaixona pela sua beleza depois de a matar, mas comandando os esquadróes de Amazonas (1.490). Surge como uma imagem de desafio, de coragem, e não de submissão (Putnam 1998: 35-6):

\section{Ducit Amazonidum lunatis agmina peltis}

Penthesilea furens, mediisque in milibus ardet, aurea subnectens exsertae cingula mammae bellatrix, audetque uiris concurrere uirgo. (1.490-93)

"Chefia os esquadrões das Amazonas de escudos em forma de lua Pentesileia em fúria e arde no meio de milhares, com o cinturão dourado apertado por baixo do seio nu, guerreira, ela que, sendo uma jovem mulher, ousa combater

[com homens."

Lyne 1987: 209-10 e Horsfall 1990: 137-8 e 1995: 106-8.

9 Acerca da inverosimilhança que subjaz à consagração de um templo a Juno pelos Cartagineses, cf. Hexter 1992: 355ss..

${ }_{10}$ Pigon 1991: 48 considera que as imagens do templo representam a fatalidade do destino dos Troianos e a crueldade dos Aqueus, que têm como auge a descrição do cadáver de Heitor arrastado pelos cavalos de Aquiles e Príamo em posição de súplica, funcionando as imagens que se seguem (a do próprio Eneias, de Mémnon e de Pentesileia) como uma forma de diminuir a tensão para preparar a chegada de Dido. 
A antítese que opóe uiris 'com homens' e uirgo 'uma jovem mulher' no verso 1.493 permite vislumbrar uma das motivaçóes mais importantes da imagem de Pentesileia, que se baseia na relação dos sexos masculino e feminino. Como Diana ou Harpálice, também as Amazonas desprezam os homens e se regem por regras consideradas anormais para uma mulher. Como as Espartanas, pegam em armas e desempenham um papel activo na sua comunidade ${ }^{11}$. A sequência de figuras femininas que começa com o disfarce de Vénus situa o leitor (e Eneias) no âmbito da transgressão e prepara-o(s) para a entrada de Dido em cena ${ }^{12}$.

A comparaçáo de Dido a uma série de personagens que se mantêm castas - especialmente Pentesileia e Diana - lança sobre a narrativa, de acordo com Putnam 1998: 37, uma luz sombria, enfatizando a sexualidade da rainha: "As long as she remains a virgin, which in her case means as long as she refrains from sexual involvement, she can retain her quasi-divine stance of power. Eroticism, we soon learn, will bring her only misadventure."

É, no entanto, o entusiasmo de Pentesileia que sobressai na ekphrasis e se exprime em palavras-chave como furens 'em fúria' e ardet 'arde' no verso 1.491 ou bellatrix'13 'guerreira' e audet 'ousa' no verso 1.493: preparada para o combate, embebida em ardor guerreiro e audácia. As associaçôes textuais com Dido são evidentes: o adjectivo furens e a forma verbal ardet, ambos realçados pela posição métrica, revestir-se-ão de uma importância capital na caracterização de Dido. Por fim, amor e morte unem-se na história de ambas como uma amálgama funesta e, deste modo, a contiguidade da representação de Pentesileia em combate e da imagem de Dido a entrar no templo indicia o final trágico do encontro desta com Eneias ${ }^{14}$.

${ }^{11}$ Recorde-se, para exemplificar a intervenção das mulheres espartanas na comunidade, o comentário de Aristóteles na Política (Pol. 1269b30): "Que diferença existe entre serem as mulheres a governar e os governantes serem governados pelas mulheres? É que o resultado é exactamente o mesmo."

${ }^{12}$ A propósito da importância da associação de Dido a Diana e Pentesileia, afirma Pigon 1991: 52: "Diana and Penthesilea represent, therefore, two sides of Dido's position and personality: one bright, the other dark." Diana corresponde a Dido como monarca casta, enquanto Pentesileia representa a exacerbação e o arrebatamento que se apoderarão da rainha.

13 Palavra que ocorre apenas duas vezes na obra: no verso citado, caracterizando Pentesileia, e em 7.805, referindo-se a Camila.

${ }^{14}$ Cf. Conte 1986: 194-5, Moskalew 1982: 132-3, Smith 1997: 33 e Putnam 1998: 37. 
Quando os olhos deste se detêm na imagem da rainha das Amazonas, aparece Dido:

\section{Haec dum Dardanio Aeneae miranda uidentur, dum stupet, obtutuque haeret defixus in uno, regina ad templum, forma pulcherrima Dido, incessit magna iuuenum stipante caterua. (1.494-7)}

"Enquanto estas cenas espantosas são contempladas pelo dardânio

[Eneias, enquanto as admira, estupefacto, e se mantém preso num único [olhar, a rainha Dido, de belíssima aparência, entrou no templo, acompanhando-a uma numerosa multidão de jovens".

A transição entre os dois momentos é abrupta, produzindo uma espécie de sobreposição da imagem das duas mulheres, acentuada pela simultaneidade que a conjunção temporal impóe e pela importância que assume o sentido da vista. A substituição de uma imagem pela outra acontece perante os olhos de Eneias que se adivinha estático, defronte da imagem de Pentesileia, estupefacto. Os recursos de Vénus (o disfarce e o relato do passado de Dido) e a visualização de momentos dolorosos da guerra de Tróia, especialmente a imagem de Pentesileia, preparam o espírito de Eneias para este momento. Eneias já sabe que está perante uma mulher diferente, que, como ele, muito sofreu, que já realizou o que ele ainda almeja.

Quando Dido, forma pulcherrima "de aparência belíssima”, (1.496), entra majestaticamente no templo, acompanhada por uma multidão de jovens, parece rodeada por uma aura divina, já que é, logo de seguida, comparada a Diana. A presença de Diana no texto, ainda que esta não participe na acção, demonstra até que ponto são importantes alguns parâmetros da caracterização da deusa que figuras como Pentesileia ou Harpálice partilham.

Também Dido participa neste universo de mulheres que assumem posiçóes de liderança. No entanto, o símile que aqui associa a rainha de Cartago à deusa da caça é mais complexo, ultrapassa a questáo da transgressão do cânone feminino que, no livro 1, parece ocupar um lugar de destaque, se tivermos em conta a galeria de figuras femininas que podem ser catalogadas como transgressoras, isto é, como mulheres que se desviam de características consideradas femininas como a fraqueza e a passividade: 
1. O disfarce de Vénus (1.314ss.):

a) armas de jovem espartana (1.315-6),

b) comparada à trácia Harpálice (1.316-7),

c) faz lembrar Diana a Eneias (1.329),

d) conta a história das façanhas inusitadas de Dido a Eneias (1.340-68).

2. Em Cartago, quando Eneias contempla as imagens do templo de Juno (1.453ss.), a última imagem que vê é a de Pentesileia (1.490-3).

3.Dido surge perante os olhos de Eneias (1.494-7) e é comparada a Diana (1.498-502).

Da caracterização de todas estas figuras femininas sobressaem elementos de cariz venatório. Vénus, como as supostas irmãs que procura, está equipada para a caça e também transporta a aljava ${ }^{15}$. O mesmo acontece com Diana, que, apesar de o símile náo fazer referência à actividade venatória, traz também consigo a aljava (1.500-1) e com Pentesileia, uma vez que a descrição desta em combate impóe que a imaginemos armada. O próprio Eneias, quando encontra Vénus, está armado. $\mathrm{O}$ encontro entre mãe e filho, preparados para caçar (ou para combater?), aliado ao facto de também Dido, como caçadora, se equipar com a aljava, quando sair para a caçada que definirá o seu destino, e analisado em conjunto com o símile (4.68-73) que a compara, apaixonada, a uma corça ferida, leva-nos, no seguimento de Lyne 1987: 194ss., a questionar o papel das personagens na relação predador - presa. No livro 1, não há ainda vítimas. Associada a Diana e a Pentesileia, Dido parece pertencer também a esta sequência de figuras preparadas para caçar, actividade que, de acordo com Cairns 1989: 31, evoca qualidades de um bom monarca.

A comparação de Dido a Diana retoma o símile que na Odisseia associa Nausícaa a Ártemis ${ }^{16}$, adaptação que desde a Antiguidade

${ }^{15}$ Namque umeris de more habilem suspenderat arcum / uenatrix (...) (1.318-19) "É que, de acordo com o costume, transportava suspenso do ombro o arco manejável"; uidistis si quam hic errantem forte sororum, succinctam pharetra et maculosae tegmine lyncis (...) (1.322-3) "Vistes por acaso vagueando por aqui alguma das minhas irmãs, munida de aljava e coberta com a pele malhada de uma fêmea de tigre?"; uirginibus Tyriis mos est gestare pharetram (...). (1.336) "é costume das jovens tírias trazer consigo a aljava".

16 Também Apolónio de Rodes na Argonáutica 3.876-84 compara Medeia a Ártemis. 
tem suscitado algumas críticas ao engenho virgiliano ${ }^{17}$. De facto, a associação de Nausícaa a Ártemis parece mais natural, mais óbvia: Nausícaa é uma jovem, inconsequente, entretida com brincadeiras com as aias. Dido casou e é já viúva e tem a seu cargo toda uma cidade, tem responsabilidades que Nausícaa desconhece, e é no exercício destas responsabilidades que é comparada a Diana brincando com os coros de ninfas.

As situaçôes enunciadas têm em comum, além da multidão que acompanha cada um dos elementos (Dido acompanhada por uma multidão de jovens, Diana por uma multidão de Oréades), o facto de se desenrolarem em lugares de culto (Dido junto do templo de Juno, Diana junto do Eurotas e do monte Cinto).

De acordo com Cairns 1989: 130-1, o principal efeito da adaptação do símile é, apesar das diferenças, a associação que estabelece entre Dido e Nausícaa. Se, numa primeira análise, parecem nada ter em comum, as semelhanças não são despiciendas: ambas prestam ajuda a um herói em dificuldades; o casamento é uma preocupação para uma e para a outra, ainda que as circunstâncias sejam diferentes; dispóem ambas de pretendentes que desprezam e, se Nausícaa representa um risco sério para o regresso de Ulisses a casa, Dido compromete o destino de Eneias.

Segundo Pöschl 1962: 65ss., o objectivo do símile é o resultado que este tem na mente de Eneias, centrando a atenção deste em Dido. Comparada a Diana, Dido parece ter uma pose celestial, como se estivesse revestida de uma estatura divina. Cresce perante os olhos ávidos de Eneias que vão sendo conduzidos através da sequência de imagens femininas esquematizada acima.

As semelhanças que Eneias reconhece entre o destino de Dido e o seu (ambos exilados, obrigados a procurar refúgio em terras estrangeiras) e o facto de Dido se encontrar em pleno trabalho de fundação suscita em Eneias a admiraçáo por aquela mulher que parece a materialização do seu próprio destino. Assim, o símile dá continuidade ao artifício de Vénus: Eneias continua a ser propositadamente atraído para Dido, como uma borboleta para uma vela acesa, despojado de qualquer tipo de desconfiança para com os Cartagineses.

Também Dido, como Eneias, é influenciada pelo primeiro encontro de ambos. Quando a nuvem que o escondia enquanto assistia ao diálogo da rainha com os seus companheiros se

${ }^{17}$ Cf. Gel. 9.9, 9.14-17. 
desvanece, tendo esta acabado de exprimir o desejo de Eneias estar presente (1.575-8), o Troiano aparece "semelhante a um deus" (1.589), como um deus ex machina. Vénus intervém uma vez mais na forma como Dido e Eneias se encontram. Depois de ter despertado no filho a admiração pela rainha, é a vez de os olhos desta ficarem deslumbrados com a aparência de Eneias, realçada para o efeito pela deusa:

Restitit Aeneas claraque in luce refulsit, os umerosque deo similis; namque ipsa decoram caesariem nato genetrix lumenque iuuentae purpureum et laetos oculis adflarat honores. (1.588ss.)

"[a nuvem afastou-se mas] Eneias ficou para trás e resplandeceu à [claridade da luz, semelhante a um deus no rosto e na estatura; é que a própria mãe tinha insuflado na cabeleira do filho a beleza, na sua juventude

[um brilho]

purpúreo e no seu olhar uma beleza jovial."

O aspecto físico de Eneias actua, segundo Cairns 1989: 30, em conjunto com a descrição que Ilioneu fez, na presença de Dido, do Troiano como um chefe virtuoso (1.544-5), criando na rainha uma expectativa favorável em relação àquele. De acordo com o mesmo autor, o facto de as primeiras palavras de Ilioneu serem um elogio às qualidades de Dido enquanto monarca e de Eneias ser apresentado como rex insuperável, faz com que Dido se sinta desafiada a emulá-lo e, consequentemente, a acolher os Troianos de forma hospitaleira. Assim Citereia manipula o espírito de Dido e de Eneias, cada um deles comovido pelo aspecto e pelos acontecimentos do passado do outro ${ }^{18}$.

No livro 1, Eneias parece passar por um processo de preparação mental que funciona como meio de apaziguar o espírito angustiado dos Troianos ${ }^{19}$. Só Vénus continua a desconfiar e a velar pela segurança do filho, recorrendo a ardis que dominem o espírito dos Tírios e da sua rainha, pela primeira vez caracterizados de forma

${ }^{18}$ Obstipuit primo aspectu Sidonia Dido / casu deinde uiri tanto (...) (1.613-4) "A Sidónia Dido ficou estupefacta primeiro por causa da sua aparência, depois por causa da tão grande infelicidade do herói.".

${ }^{19}$ O próprio relato da guerra de Tróia é uma catarse para Eneias, que, assim, parece deixar para trás o passado. 
manifestamente negativa ${ }^{20}$. Mesmo depois da intervenção de Mercúrio junto dos Troianos, Vénus continua a temer a natureza de Dido e dos seus súbditos e faz Cupido assumir o papel de Ascânio, para instilar na rainha furentem 'em fúria' (1.659) o fogo da paixão. O facto de ser Vénus quem, pela primeira vez, atribui a Dido o furor que assumirá um papel de relevo no livro 4, além do indício que introduz no texto, parece provar realmente que só a deusa teme ainda os Cartagineses e conhece a sua verdadeira natureza. Diz a Cupido:

Tu faciem illius noctem non amplius unam falle dolo, et notos pueri puer indue uoltus, ut, cum te gremio accipiet laetissima Dido regalis inter mensas laticemque Lyaeum, cum dabit amplexus atque oscula dulcia figet, occultum inspires ignem fallasque ueneno.' (1.683ss.)

“Tu, engana-os com este dolo: durante não mais do que uma [noite, assume o rosto dele e, tu que és um menino, toma a fisionomia

[conhecida de outro menino, de modo a que, quando Dido, muito alegre, te acolher entre as mesas do palácio real e o líquido de Lieu, quando te abraçar e te der doces beijos, tu instiles nela o fogo oculto e a enganes com veneno."

Ao recorrer, mais uma vez, à dissimulação, Vénus vale-se do instinto maternal de Dido. O facto inesperado de Cupido náo ser descrito com os traços tradicionais de arqueiro, no contexto do livro $1 \mathrm{em}$ que, como vimos, as armas parecem assumir um peso e significado especiais, acentua o poder do seu disfarce. Dido, assim enganada, não podia resistir à ternura da criança que a contagia. A antítese entre amplexus abraços e oscula dulcia doces beijos no verso 1.687, por um lado, e occultum... ignem fogo oculto e ueneno com veneno no verso 1.688 , por outro, acentua a crueldade do artifício utilizado por Vénus. De acordo com Stroppini de Focara 1990: 23ss., o estratagema utilizado por Vénus surge perante o leitor como um processo bem mais repugnante do que os anteriores, que visam atrair Dido e Eneias: "C'est aller trop profond dans ce

${ }^{20}$ Domum timet ambiguam Tyriosque bilinguis; (1.661) "teme uma casa enganadora e os Tírios sem palavra”. 
que les êtres ont d'essentiel, de sacré, c'est toucher au coeur de la nature humaine et passer les bornes permises à qui veut se venger: à ce niveau les êtres n'ont plus ni défense ni refuge, et la déloyauté tourne à la cruauté monstrueuse." Nutall 1998: 92 caracteriza o estratagema de Vénus como "half-blasphemy". Vénus e Cupido exploram, assim, o desejo que Dido tem de ser máe para a "infectar" com a paixão por Eneias e a rainha torna-se vítima da manipulação divina e da sua própria vulnerabilidade.

E é assim que, no conforto do seu palácio, a rainha vai sendo envenenada. O cenário do dolo é, por si só, um sinal de condenação ${ }^{21}$. A descrição do palácio de Dido (1.637-42; 1.697708) é significativa na expressão da opulência e da riqueza e contrasta com duas outras residências em que Eneias é acolhido: no livro 7, o rei Latino recebe os Troianos no palácio de Pico, que tem como característica mais marcante o peso da representação da história e a veneração dos antepassados; no livro 8, Evandro recebe Eneias humildemente no bosque em que oferece um sacrifício. Assim, a riqueza do palácio de Dido, a tradicional riqueza oriental, contrária ao espírito romano, estabelece uma diferença fundamental, uma barreira intransponível entre os Tírios e os Troianos. A aliança entre os dois povos é impossível e a relação de Dido e Eneias, que evoca a ligação funesta entre Cleópatra e Marco António, não pode ter futuro.

Assim, desde o início, a tragédia de Dido adivinha-se no poder inexorável dos estratagemas de Vénus e em alguns vislumbres, pouco abonatórios, da sua índole. Dido está condenada. E, se a natureza do seu espírito só é evidente para a deusa, os indícios que vão sendo introduzidos na narrativa fazem a imagem da rainha oscilar entre a imponência e a desmesura, entre a racionalidade e a castidade de Diana e o arrebatamento apaixonado e sem escrúpulos de Vénus. Esta dualidade e a confusão que cria na própria Dido são, assim, introduzidas na obra pela imagem ambivalente de Vénus caracterizada como Diana ${ }^{22}$. Como afirma Suzuki 1989: 105 , "the goddess of love's masquerade as the goddess of virginity will find an ironic corollary in Dido's transformation from a chaste queen to an impassioned lover."

E é assim que começa o livro 4: Dido completamente

${ }^{21}$ Pavlock 1990: 76-7 comenta as implicaçóes morais de ordem negativa que as referências ao ouro e à riqueza introduzem no texto.

${ }^{22}$ Hardie 1997: 321ss. afirma que Virgílio juntou numa única imagem as epifanias de Afrodite e de Ártemis no início e no fim do Hipólito de Eurípides, respectivamente, associando, assim, a tragédia de Dido a esta obra. 
conquistada pelo amor, vencida, portanto, pelo estratagema de Vénus. Depois da manipulaçáo divina, a paixão que Dido sente por Eneias é fisicamente evidente.

Os primeiros versos descrevem a paixão da rainha mediante duas imagens que se tornam recorrentes no episódio: a imagem do amor como fogo e como ferida. A caracterização do amor da rainha como um fogo surge no livro 1 , na descrição do ardil de Vénus e Cupido (1.659-60; 1.673-4; 1.687-8; 1.712-14). O efeito que este, assumindo o aspecto do pequeno filho de Eneias, tem em Dido é coadjuvado pelos presentes que o acompanham quando Acates o traz das naus para Cartago (1.714), presentes que Eneias trouxe de Tróia, depois de salvos do fogo que consumiu a cidade (1.679) e que parecem transmitir à rainha o fogo funesto que a vai destruir, fogo metafórico da paixão, que, de quando em quando, se manifesta como realidade física (4.66-7). Será precisamente este fogo materializado o que incendiará a pira funerária e consumirá, então literalmente, o corpo da rainha.

A chama da paixão é também um veneno que invade o corpo de Dido (1.688), é uma realidade que congrega aspectos físicos e psicológicos, que joga com o corpo e com a alma da rainha. É um amor que Dido "bebe" (1.749), um amor que é doença (4.8), que é uma ferida aberta, ferida psicológica que, como o fogo, evoluirá também no sentido da materialização.

É este amor, poderoso e invasivo, que domina a rainha quando, ouvida a narrativa da queda de Tróia, surge perante Ana:

\section{At regina graui iamdudum saucia cura}

uulnus alit uenis, et caeco carpitur igni. (4.1-2)

"E a rainha, atingida há muito por um grave cuidado de amor, alimenta uma ferida com as suas veias e é enfraquecida por um [fogo oculto."

Dido está inquieta e atormentada (4.5) por um sentimento que deixara, desiludida, no passado ${ }^{23}$ e que agora, inesperadamente, a invade de forma invulgarmente violenta. Seduzem-na a aparência física de Eneias e os sofrimentos que acabou de descrever. Os sintomas e causas da paixão de Dido são físicos e psicológicos e esta duplicidade, assim abrangente, devastará, gradualmente, a rainha.

${ }^{23}$ Afirma em 4.23: adgnosco ueteris uestigia flammae "reconheço os traços da antiga chama”. 
Aparentemente determinada em se manter fiel ao seu defunto marido, Dido afirma perante a irmã que, se não lhe repugnasse a ideia de um novo casamento, apenas Eneias poderia ser o eleito (4.15-19). A repulsa desta ligação hipotética, que parece considerar impossível, leva a rainha a formular um juramento de fidelidade às cinzas de Siqueu, juramento em que exprime o desejo de se manter uniuira ${ }^{24}$ :

sed mihi uel tellus optem prius ima dehiscat uel pater omnipotens abigat me fulmine ad umbras, pallentis umbras Erebo noctemque profundam, ante, pudor, quam te uiolo aut tua iura resoluo. ille meos, primus qui me sibi iunxit, amores abstulit; ille habeat secum seruetque sepulcro. (4.24-9)

"Que as profundezas da Terra se abram para mim ou o Pai omnipotente me afaste com o seu raio para as sombras, para as pálidas sombras, para o Érebo e para densidão da noite, antes de que eu te ofenda, pudor, ou atente contra as tuas leis. Aquele que foi o primeiro a unir-me a si foi esse quem levou consigo o meu amor; que consigo o mantenha e o guarde na [sepultura."

Pöschl 1962: 76 realça a importância do juramento como vector de auto-condenação: "It is a curse on herself that is destined to be cruelly fulfilled." De facto, Dido há-de violar o juramento de fidelidade a Siqueu, mas expiará, com a morte, a sua falta. Tenha este voto sido pronunciado com convicção ou não, rapidamente os conselhos de Ana dissolveram os últimos escrúpulos da mente de Dido. Recordando-lhe a fragilidade da sua condição de mulher e as vantagens que uma união com Eneias lhe concederia, quer a nível pessoal, quer a nível público, Ana faz com que a irmã esqueça as palavras que acabou de proferir. $\mathrm{O}$ desejo de ser mãe, a vulnerabilidade do reino ameaçado pelos povos vizinhos e a

${ }^{24}$ I. e. mulher que só teve um marido. Este desejo determina, de acordo com alguns autores, a condenação moral de Dido. Ainda que os Romanos encarassem o casamento das viúvas com naturalidade, as uniuirae eram frequentemente alvo de rasgados elogios, o que demonstra que, pelo menos enquanto situação idealizada, o estatuto merecia considerável aprovação moral. De acordo com Treggiari 1993: 236, "Remarriage was not morally objectionable to pagan writers, except when they wanted to take a particularly high moral line, although lifelong monogamy for women was morally better and luckier." 
esperança depositada na aliança com os Troianos vencem a culpa (4.19) de uma nova relaçáo.

De seguida, Ana e Dido procuram atrair a boa-vontade dos deuses para a união com o Troiano, mediante sacrifícios a que a própria rainha preside. É ela quem imola as vítimas e consulta as suas entranhas, ritual que, de acordo com Pavlock 1990: 74, chocaria um Romano. Austin 1982: ad loc. considera, pelo contrário, que Dido é descrita na sua dignidade de rainha: "She is the Queen, a noble and commanding figure." Para Spence 1999: 84, o comentário que o próprio narrador faz aos sacrifícios reflecte sobre eles uma luz ambígua:

heu, uatum ignarae mentes! quid uota furentem, quid delubra iuuant? est mollis flamma medullas interea et tacitum uiuit sub pectore uulnus. (4.65-7)

“Oh, mentes ignaras dos profetas! De que lhe servem, no seu [estado de fúria, os votos? De que the servem os templos? Entretanto uma chama devora-lhe [as ternas entranhas e uma ferida oculta vive no seu peito."

Ao referir a chama que lhe devora as entranhas, não é imediatamente claro se se trata do fogo real do sacrifício ou do fogo metafórico da paixão, se as entranhas são dos animais sacrificados ou de Dido. Só no verso seguinte se torna evidente que se trata do fogo da paixão que, metaforicamente, consome o corpo da rainha. No entanto, o facto de se suscitar, ainda que momentaneamente, esta dúvida, faz com que Dido se identifique com a vítima destes sacríficios.

Como quer que se entenda o passo, de forma reprovável ou dignificante, parece que enfatiza, antes de mais, a rapidez com que a rainha adere, sem freios, à força da paixão, paixão que é, novamente, caracterizada como fogo e como ferida e que é amplificada pelo símile que compara Dido a uma corça:

uritur infelix Dido totaque nagatur

urbe furens, qualis coniecta cerua sagitta,

quam procul incautam nemora inter Cresia fixit

pastor agens telis liquitque nolatile ferrum

nescius: illa fuga siluas saltusque peragrat

Dictaeos; haeret lateri letalis harundo. (4.68-73) 
"Arde a infeliz Dido e vagueia, enlouquecida, por toda a cidade, como, depois de lhe lhe ter sido arremessada

[uma seta, uma corça que, imprudente, foi trespassada nos arvoredos de Creta por um pastor que, avançando armado, deixou para trás

[o ferro volátil,

sem saber; ela percorre em fuga os bosques e as florestas do monte Dicte; a flecha mortal ficou-lhe cravada no flanco."

O símile vem no seguimento da exploração de tópicos de cariz venatório que se inicia no livro 1 . Dido é comparada, na perturbação do seu deambular pela cidade, a uma corça ferida por um pastor... nescius, à letra "por um pastor que não sabe" (4.71-2). Se é evidente a associação de Dido à corça atingida, a identificação da entidade que a feriu tem suscitado alguma polémica. Lyne 1987: 194-8 é peremptório ao afirmar que Dido é vítima de Eneias e não de Cupido, uma vez que este não é caracterizado na Eneida como arqueiro. Por outro lado, ainda que o adjectivo nescius pareça inocentar Eneias da acusação de ter ferido Dido, o autor considera que o que ele desconhece é que, efectivamente, uma das suas setas atingiu o alvo. Nesta interpretação, assume especial importância o facto de o pastor aparecer no símile preparado para a caça, agens telis, 'avançando armado' (4.71), o que significa que, por detrás do acto que vitima Dido, existe a intenção de a ferir. Assim, Eneias não será completamente inocente na relação violenta predador-presa que o símile implica. Afirma Lyne 1987: 196: "He [Eneias] has courted the queen, made up to the queen, 'hunted' her in the hunt of love. What he does not know - yet is that his courtship has been devastatingly and lethally successful (...)." Consequentemente, Eneias intervém, de forma intencional, na paixão de Dido.

Horsfall 1995: 124-5 contesta esta interpretação e afirma que a rainha é vítima de Vénus e Cupido e não de Eneias, já que é Dido quem, na relação com o Troiano, assume o papel de amante, o papel activo. Dido ama Eneias; Eneias é amado por Dido. Logo, o pastor nescius não pode ser identificado com Eneias, já que o símile retrataria, assim, uma inversão nos papéis da relação amorosa.

É, no entanto, seguro que Dido é a vítima de um acto violento operado por uma entidade preparada para a caça. Moskalew 1982: 166-7 relaciona este símile com as imagens venatórias que são introduzidas no episódio desde o livro 1: Eneias caçando 
uma manada de veados (1.184ss.), e Vénus disfarçada como uma jovem caçadora (1.314ss.). Quanto a Cupido, arqueiro ou não, o certo é que também ele exerce sobre Dido uma influência nefasta. Também ele vitima Dido de uma forma deveras violenta. Assim, Dido é vítima de uma acção concertada, de carácter predatório e muito poderosa.

É precisamente o poder do amor de Dido, a violência (e também a rapidez...) com que a paixão se apoderou da rainha, completamente submetida pela "ferida" que a consome, que sobressai da descrição da corça. Comenta Pavlock 1990: 75: (...) "the simile here increases the pathos of Dido's suffering because it is so sudden and to some extent outside of her control." O amor de Dido torna-se obsessivo, fá-la procurar a companhia de Eneias (4.74-5; 4.77-9), vê-lo e ouvilo quando não está presente (4.83-4), esquecer as suas obrigaçóes de rainha (4.86-9)... Assim alienada, Dido perde a lucidez, a racionalidade e a força que a caracterizavam quando, no templo de Juno, organizava o seu reino. Assim, de acordo com Spence 1999: 83, o paralelismo entre Dido e Eneias, que era evidente no livro 1 e que atraiu as personagens uma para a outra, desaparece quando Dido passa a ser vítima da sua própria paixão. É esta mudança, esta nova perspectiva que, de acordo com a autora, é ilustrada no símile: enquanto Dido é identificada com a vítima, o papel de Eneias é dúbio, mantém-se, propositadamente, enigmático. Esta dualidade domina todo o episódio.

A responsabilidade de um e outro no decorrer dos acontecimentos é igualmente difícil de definir. A intervenção dos deuses, as maquinaçôes de Juno e de Vénus tornam nebulosa esta questão. Saber se Dido é ou não responsável por uma paixão assim avassaladora e auto-destrutiva, se Eneias fomenta, intencionalmente ou sem querer, os sentimentos da rainha tem dado origem a um debate prolixo e inconclusivo. Teria Dido amado Eneias se os deuses não tivessem manipulado os seus sentimentos? Lyne 1987: 66ss. entende que Vénus explora sentimentos já existentes na rainha, aproveitando a sua vulnerabilidade e a atracção que sentiu por Eneias para criar nela uma paixão desenfreada. Se associarmos esta vulnerabilidade ao desejo de ser mãe, que não realizou no primeiro casamento, e à fragilidade política do seu reino, Dido seria, então, a vítima ideal para os planos das duas deusas. Vénus manipula a rainha para garantir a segurança do seu filho, Juno engendra a união de ambos para afastar Eneias do seu destino. Dido é, assim, a 
presa de uma perseguição (desigual...) de cariz venatório: a corça ferida.

A caça metafórica representada no símile consubstancia-se na caçada em que Dido e Eneias se unem na caverna.

Speluncam Dido dux et Troianus eandem deueniunt: prima et Tellus et pronuba Iuno dant signum; fulsere ignes et conscius aether conubiis, summoque ulularunt uertice nymphae (4.165-8)

"Dido e o chefe troiano vieram para a mesma gruta: primeiro, a Terra e Juno que preside ao matrimónio dáo o sinal. Luziram clarôes e o éter cúmplice da união. Do cimo de um monte uivaram as ninfas."

A natureza desta união é a base da tensão subsequente. Juno, apercebendo-se do estado deplorável em que Dido se encontra possuída por um amor nefasto (4.90), esquecida da sua reputação e entregue aos devaneios da paixáo (4.91) -, planeia com Vénus uma aliança entre as duas (4.102-4). Juno pretende manter o Troiano em Cartago, oferecendo-lhe, como dote, o poder sobre os Cartagineses. Assim, de acordo com as palavras da deusa, Dido é apenas um meio de conseguir o fim que aquela se propóe. Atente-se na descrição que Juno faz dos sentimentos da rainha, que caracteriza ironicamente como presa de Vénus e Eneias:

egregiam uero laudem et spolia ampla refertis tuque puerque tuus (magnum et memorabile numen) una dolo diuum si femina uicta duorum est. (4.93-5)

"Alcançais louvor sem igual e arrecadais despojos magníficos tu e o teu rapaz (é grande e digno de memória o poder divino!) se uma única mulher é vencida pelos embustes de dois deuses."

e acrescenta a constatação de que o amor de Dido por Eneias é obra de Vénus:

Habes tota quod mente petisti:

ardet amans Dido traxitque per ossa furorem. (4.100-1)

"Conseguiste o que tão empenhadamente procuraste:

Dido arde, apaixonada, e faz a loucura percorrer os seus ossos." 
Planeia então uni-los num conubio... stabili, numa "união duradoura” (4.126), se Vénus concordar (4.125). Ludibriada por esta, Juno póe o seu plano em marcha, desencadeia a tempestade que traz Dido e Eneias para a mesma gruta e preside à união de ambos, convencida da sua legitimidade. De acordo com Austin 1982: ad 166, a descrição dos acontecimentos assume o carácter de uma cerimónia nupcial em que as testemunhas são entidades sobrenaturais: os elementos (a Terra, o Fogo, o Ar), Juno (a divindade que preside aos casamentos legítimos) e as ninfas. Pavlock 1990: 80 comenta assim a união e a forma como esta é descrita na obra: "Vergil also gives some credibility to the existence of a marriage, since the union was orchestrated by the marriage-goddess Juno and included symbolic elements of a formal ceremony: the lightning flashes substituting the wedding torches and the music of the nymphs for the wedding song." Horsfall 1995: 128ss. afirma que os presságios que presidiram à união são uma paródia dos que deveriam estar presentes numa verdadeira cerimónia nupcial ${ }^{25}$ e que, portanto, Dido não pode ser considerada a esposa legítima de Eneias. $\mathrm{O}$ autor considera que Dido utiliza esta pretensão para esconder a sua culpa, iludindo-se a si própria:

ille dies primus leti primusque malorum causa fuit; neque enim specie famaue mouetur nec iam furtiuum Dido meditatur amorem coniugium uocat; hoc praetexit nomine culpam. (4.169-72)

"Aquele primeiro dia foi a causa da sua morte, aquele primeiro dia foi a causa dos seus males; pois Dido não se abala com as aparências nem reflecte já num amor furtivo:

[ou com a sua reputação, chama-lhe casamento; com este nome dissimulou a culpa."

Como quer que se entenda a cerimónia, legítima ou não, o comentário que segue a descrição da união de Dido e Eneias obsta à interpretação desta como um acto cândido. Se a própria rainha se ilude, é porque sente, de algum modo, que o que aconteceu é reprovável.

As referências ao ouro e à púrpura que dominam a descrição

${ }^{25} \mathrm{O}$ autor refere ainda o facto de, aos olhos de um Romano, ser impossível o casamento entre ambos, já que Dido é uma mulher estrangeira e Eneias a representação dos ideais romanos. 
da aparência da rainha, antes de partir para a caça (4.134-8), implicam, de acordo com Pavlock 1990: 77, uma condenação moral, patente já na descrição da opulência do palácio ${ }^{26}$. Assim, desde o início, Dido é apresentada como moralmente reprovável. Eneias, pelo contrário, sai para a caça ante alios pulcherrimus omnis "mais belo do que todos os outros" (4.141). O símile que o compara a Apolo eleva-o à estatura de um deus, como Dido comparada a Diana no livro $1^{27}$. A oposiçáo entre os dois, na hora de partir para o encontro fatal, é evidente. No entanto, quando Mercúrio se desloca a Cartago para admoestar Eneias, a descrição da aparência deste retoma o tópico da opulência excessiva (4.25964), como se, adormecido no conforto de Cartago, Eneias tivesse sido contagiado pelos valores de Dido ${ }^{28}$.

De facto, depois dos acontecimentos da caverna, é a influência nefasta da Fama que faz desmoronar o idílio em que Dido e Eneias se encontram. Advertido pelas preces de Jarbas, Júpiter envia Mercúrio a Cartago. Aterrorizado, Eneias prepara a partida em segredo, já que não sabe como dirigir-se à rainha, e adia o confronto com Dido. Todavia, quando esta descobre que os Troianos se preparam para partir sem nada dizer, reage de forma violenta:

Saeuit inops animi totamque incensa per urbem

bacchatur, qualis commotis excita sacris

Thyas, ubi audito stimulant trieterica Baccho

orgia nocturnusque nocat clamore Cithaeron. (4.300-3)

"Privada de razão, encoleriza-se e vagueia como louca por toda a cidade, como uma Tíade ${ }^{29}$ excitada pela preparação das cerimónias rituais, quando, ao ouvir o nome de Baco, a incitam as orgias trienais e, pela noite, o Citéron a chama aos brados."

${ }^{26}$ Comenta a autora: "The moral overtones of both contexts reinforce the negative connotations of gold as a symbol of decadence. One may recall that Dido acquired her wealth under violent circumstances, after her husband had been murdered for his riches, and she herself stole away with it without her brother' s knowledge."

${ }^{27}$ Lyne 1987: 123-5 comenta este símile como a associação de Eneias ao atributo de Apolo como "plague-bringer", como provocador da peste que invadiu Dido.

${ }^{28}$ Austin 1982: ad 260 comenta: “(...) it is a Tyrian Aeneas with a jewelled sword and purple cloak, a Tyrian Aeneas, dressed out in magnificence by Dido, not a grave and sober man of destiny."

${ }^{29}$ I. e. uma Bacante. 
Atente-se no retomar do motivo da errância pela cidade, já presente no símile da corça ferida (4.68-9). Naquele momento, numa fase incipiente (ainda que violenta...) da sua paixão, Dido percorre a cidade movida pelo poder desenfreado do amor que a fere. Depois de saber que Eneias vai partir, paixão e raiva aliamse, no espírito da rainha, formando uma amálgama fatal que a leva à loucura. A inquietação que revela no diálogo com Ana transforma-se em demência e esta assume proporções báquicas (Moskalew 1982: 171). Como uma bacante, Dido está possuída, como demonstra o acumular de verbos e adjectivos que exprimem o seu estado de espírito desequilibrado. Este estado alterado, desenfreado, evolui, ao longo do episódio. No livro 1, Dido surge perante Eneias de uma forma majestática, no seu papel de rainha. No entanto, o sobrepor da sua imagem entrando no templo à representaçáo de Pentesileia furens deixa adivinhar na caracterização de Dido o desequilíbrio que a dominará no livro 4: primeiro, fazendo-a vaguear pela cidade como uma corça ferida, depois como uma Ménade em transe.

Hershkowitz 1998: 37 acentua a pertinência da associação estabelecida pelo símile. De facto, a loucura de Dido é, como o furor de uma bacante, inspirada simultaneamente por forças externas e internas, pela acção divina, nomeadamente de Vénus, Juno e Cupido, e pelo confronto psicológico desencadeado pela relação com Eneias.

São circunstâncias agravantes da agitação da rainha o facto de, sem esperar pelas explicaçóes de Eneias, irromper em acusaçóes:

Dissimulare etiam sperasti, perfide, tantum posse nefas tacitusque mea decedere terra? nec te noster amor nec te data dextera quondam, nec moritura tenet crudeli funere Dido? (4.305-8)

"Esperaste mesmo, pérfido, poder dissimular tamanho crime e deixar, sem dizer palavra, as minhas terras?

Não te detêm o nosso amor nem a mão direita que em tempos te estendi ${ }^{30}$, nem Dido que há-de morrer de forma cruel?"

O discurso da rainha começa de forma violenta - perfide 'pérfido' (4.305), crudelis 'cruel' (4.311) -, mas vai-se tornando mais suave e pessoal: mene fugis? "é de mim que foges?" (4.314). As acusaçóes dáo lugar às preces:

${ }^{30}$ Em sinal de aliança. 
Per ego has lacrimas dextramque tuam te (quando aliud mihi iam miserae nibil ipsa reliqui), per conubia nostra, per inceptos hymenaeos, si bene quid de te merui, fuit aut tibi quicquam dulce meum, miserere domus labentis (...) (4.314-8)

"Peço-te eu por estas lágrimas e pela mão direita que me estendeste (já que eu própria, coitada, não deixei para mim nenhuma

pela nossa união, pelos himeneus iniciados, [outra coisa), se de alguma forma procedi bem em relação a ti, ou algo em mim foi agradável para ti, tem piedade da minha casa que desaba..."

O orgulho e a dignidade das cenas iniciais do episódio são substituídos pela submissão com que Dido se dirige a Eneias, descrevendo a situação periclitante em que a relação com o Troiano e a perda da boa reputação a colocaram a si e a Cartago:

\section{te propter eundem}

exstinctus pudor et, qua sola sidera adibam, fama prior. (4.321-3)

"foi por causa de ti

que a minha castidade se perdeu e a reputação que tinha antes e que, só ela, me elevava aos astros."

Entristece-a ainda a inexistência de um filho, de um paruulus Aeneas, de um "pequenino Eneias" (4.328-9) que mantivesse presentes junto de si os traços do herói. Jenkyns (1996r) 57-8 comenta o uso do adjectivo paruulus: "Our understanding of Dido is enlarged: a speech that began as high tragic rhetoric collapses into a tender, plaintive domesticity. We realise that Dido is not only a proud queen but also, with some part of her being, an ordinary woman with ordinary hopes and desires." Ao unir-se a Eneias, Dido parece ter regressado à sua condição anterior de esposa, esquecendo o seu estatuto de rainha. De esposa a rainha e de rainha a esposa, Dido atravessa paradigmas da condição feminina. Quando Eneias chegou a Cartago, Dido desempenhava de forma conveniente e digna as suas funçóes de monarca. A morte de Siqueu e a fuga de Tiro provocaram a transição: a força das circunstâncias transformou-a em rainha. O encontro com os Troianos e com Eneias parece gerar em Dido a determinação de regressar à sua antiga condiçáo de esposa. Todavia, o desejo de ter 
um filho de Eneias responde também à necessidade de assegurar a continuidade e a estabilidade do reino. Assim, a vontade de ser mãe realizaria as esperanças de Dido, quer a nível individual, quer a nível público.

A resposta de Eneias é, no entanto, devastadora para as pretensôes de Dido. Não só se mostra irredutível na sua decisão de partir, como nega que alguma vez tenha querido o casamento com a rainha (4.338-9). Eneias justifica a sua partida com a missão que os deuses lhe atribuíram de chegar ao Lácio, contando-lhe a visita de Mercúrio, os avisos de Anquises nos seus sonhos e a necessidade de não impedir Ascânio de cumprir o seu destino. Termina com a afirmação: Italiam non sponte sequor, "não é por minha vontade que me dirijo para a Itália” (4.361).

Assim, todos os pressupostos em que Dido baseara a sua relação se desmoronam. A queda da rainha torna-se iminente quando se apercebe de que foi em vão que confiou na segurança que uma união (inexistente...) traria ao seu reino. Chocada com a partida, com as palavras de Eneias, com a missáo de rumar em direcção ao Lácio (missão que Dido conhecia, mas que parecia ter esquecido...), a resposta de Dido torna-se mais violenta. A ascendência de Eneias, que antes suspeitara divina e que a encantara, é agora identificada com os elementos selvagens da natureza (4.365-7); choca-a a insensibilidade de Eneias (4.36970 ), a quem relembra a ajuda que lhe prestou quando, náufrago e necessitado, desembarcou nas costas da Líbia (4.373-5). Esquecida a ternura do discurso anterior, a fúria de Dido dilata-se com a ironia com que se refere à intervenção dos deuses, em que parece náo acreditar, e, finalmente, transforma-se em raiva:

Spero equidem mediis, si quid pia numina possunt, supplicia hausurum scopulis et nomine Dido saepe nocaturum. sequar atris ignibus absens et, cum frigida mors anima seduxerit artus, omnibus umbra locis adero. dabis, improbe, poenas. audiam et haec manis ueniet mihi fama sub imos. (4.382-7)

"Pela minha parte tenho fé de que, se algum poder têm tu sejas castigado no meio dos escolhos e de que chames [os numes piedosos, [muitas vezes pelo nome de Dido. Mesmo ausente, seguir-te-ei com fogos nefastos e, quando a fria morte separar o meu corpo e a minha alma, 
como uma sombra, estarei presente em todos os lugares. Serás [castigado, homem perverso.

Eu ouvirei essa notícia, ela virá até mim quando eu estiver entre os [Manes das profundezas".

Dido ameaça Eneias de, depois de morta, o perseguir como uma Fúria. $\mathrm{O}$ desejo de vingança começa a tomar forma nas suas palavras. A perseguição retratada no símile da corça ferida inverte-se nas imprecaçóes da rainha (Moskalew I982: 167): é ela quem quer perseguir Eneias.

Dido pede a Ana que intervenha junto do herói e que lhe peça não já que fique para sempre, mas apenas que adie a partida. Não pretende já a união que julgava existir, apenas algum tempo para que aprenda a habituar-se à ideia da partida. $\mathrm{O}$ Troiano, no entanto, continua inflexível (4.438-49) e só então Dido desiste: está cansada de viver.

O seu estado psicológico reflecte-se nas alucinaçóes e sinais funestos que se lhe deparam: nos sacrifícios, vê a água tornarse negra (4.454), o vinho transformar-se em sangue (4.455); ouve a voz do marido que a chama do templo que construiu em memória dele (4.457-61) e o canto de mau agouro do mocho (4.462-3); afligem-na também oráculos antigos (4.464-5) e vêse, nos seus sonhos, a ser perseguida por Eneias e a percorrer sozinha um longo caminho e a procurar os Tírios numa terra deserta (4.466-8). Segue-se o símile que compara o seu estado de espírito perturbado a Penteu e Orestes:

Eumenidum ueluti demens uidet agmina Pentheus et solem geminum et duplices se ostendere Thebas, aut Agamemnonius scaenis agitatus Orestes, armatam facibus matrem et serpentibus atris cum fugit ultricesque sedent in limine Dirae. (4.469-73)

"Como Penteu, demente, vê os esquadrōes das Euménides e vê aparecer dois sóis e duas cidades de Tebas, ou como Orestes, filho de Agamémnon, atormentado, no palco, quando foge da mãe armada com archotes e com negras serpentes e as Fúrias vingadoras se sentam na soleira da porta."

Hardie 1997: 322 explica a loucura de Dido, que aqui parece atingir um dos seus pontos culminantes, pelo facto de a rainha ter consumado a sua paixão fora da cidade de Cartago, ou seja, 
em territórios não civilizados. Quando regressa, traz consigo para dentro da cidade o caos e a selvajaria, e a sua loucura (como a sua relação com Eneias?) é, assim, uma fuga da civilização, tópico que se materializa no sonho de se ver sozinha em territórios desertos, náo civilizados, e na associação a uma bacante (4.300-3) e a Penteu, dilacerado pelas Ménades no monte Citéron.

Hershkowitz 1998: 26ss. afirma que o símile completa a ilustração da dimensão múltipla da demência de Dido: ela não é só Penteu, é também a Bacante (4.301-3), não é só Orestes, mas é também uma Fúria (4.384-6). Assim, Dido não é apenas identificada com a vítima. Assume também, a espaços, o papel de agente. Oliensis 1997: 305-6 analisa as implicaçóes do símile e dos passos referidos à luz do instinto maternal da rainha. Do mesmo modo que o amor de Dido é criado por influência de pai e filho, também o desejo de vingança recai sobre os dois (4.600-2).

Perturbada por alucinaçóes e sinais funestos, Dido decide morrer (4.474 -5) e ludibria Ana, dizendo-lhe que devem preparar um sacrifício que a libertará do amor a Eneias ou restituirá a relação entre ambos (4.479). Durante a noite, o mundo e os seus seres descansam, só Dido se mantém vigilante e não consegue dormir:

At non infelix animi Phoenissa, nec umquam soluitur in somnos oculisue aut pectore noctem accipit: ingeminant curae rursusque resurgens saeuit amor magnoque irarum fluctuat aestu. (4.529-32)

“Mas não [dorme] a infeliz Dido nem alguma vez se entrega

[ao sono ou acolhe o descanso da noite nos seus olhos ou no seu coração. redobram as suas penas e, regressando com toda a força, recrudesce o amor e agita-se no grande turbilhão da sua cólera.”

Atormenta-a o seu futuro. Interroga-se sobre o que fazer, na situação em que se encontra: acompanhar os Troianos, esperar a misericórdia dos pretendentes que antes desprezou? Eliminando mediante um raciocínio lógico as várias possibilidades, conclui que só a morte é solução (4.547) e lamenta não se ter mantido fiel à memória de Siqueu (4.552). Este solilóquio contrasta com a perturbação anterior e com a cólera que evidencia quando se apercebe de que Eneias e os Troianos se fazem ao mar $^{31}$. Nesse

${ }^{31}$ Austin 1982: ad 590 caracteriza assim o discurso que se segue: "The 
momento, incita os Tírios em perseguição de Eneias (4.591-4), a quem chama já não 'esposo' (4.324), nem 'hóspede' (4.323), mas 'estrangeiro' (4.591). Adivinha-se a cólera que dominará as últimas palavras da rainha, que reconhece o seu estado de demência:

\section{Quid loquor? aut ubi sum? quae mentem insania mutat? (4.595)}

"Que digo ou onde estou? Que loucura transforma a minha mente?"

Dido mostra-se arrependida dos serviços prestados aos Troianos e sarcasticamente descrente das virtudes de Eneias:

Infelix Dido, nunc te facta impia tangunt?

tum decuit, cum sceptra dabas. en dextra fidesque,

quem secum patrios aiunt portare penatis, quem subiisse umeris confectum aetate parentem! (4.596-9)

"Infeliz Dido, agora é que te incomodam os actos ímpios? Isso devia ter acontecido no momento em que lhe entregavas o ceptro.

[Eis a mão direita e a boa fé, eis aquele que dizem que transportou consigo os Penates pátrios, aquele que dizem que pôs às costas o pai enfraquecido pela idade.”

As palavras que se seguem demonstram, porém, um grau de crueldade que a rainha ainda não revelara. Dido recrimina-se por não ter agido contra os Troianos. Enumera toda uma série de acçóes violentas que poderia ter desenvolvido contra Eneias e os seus companheiros: podia ter dilacerado Eneias e lançado os seus membros ao mar (4.600-1), podia ter imolado os Troianos e mesmo Ascânio para o servir num banquete ao seu próprio pai $(4.601-2)^{32}$, podia ter incendiado o acampamento e, assim, teria aniquilado a raça dardânia (4.604-6)...

Introduzida por uma invocação ao Sol, a Juno, a Hécate, às Fúrias e aos "deuses de Elissa que está prestes a morrer" (4.610), a maldição que Dido profere é o culminar do seu ódio a Eneias. Já que o destino impôe que ele se dirija ao Lácio, a rainha pede

speech that follows must surely rank with the most magnificent of any poet in any language."

${ }^{32}$ Referências que evocam o crime de Atreu, que deu a comer o corpo dos seus sobrinhos ao irmáo, Tiestes, que, sem saber, ingeriu carne do corpo dos seus próprios filhos, e o assassínio de Absirto por Medeia, que espalhou os membros dilacerados do irmáo pelo caminho, para atrasar a perseguiçáo de Eetes. 
aos deuses que ensombrem a sua vida: que ele sofra os tormentos da guerra (4.615-6), que seja afastado de Julo (4.616), que assista à morte dos seus companheiros (4.617-8), que não desfrute do poder conseguido (4.618-19) e jaza, insepulto, na areia, morto antes do tempo (4.620)... Mas o desejo de vingança da rainha vai mais longe. Não abrange apenas Eneias, Ascânio e os companheiros troianos, mas toda a sua descendência. $\mathrm{O}$ seu ódio prolonga-se no tempo e no espaço. Amaldiçoados os Troianos, resta lançar o anátema da inimizade eterna entre os dois povos:

tum uos, o Tyrii, stirpem et genus omne futurum exercete odiis, cinerique haec mittite nostro munera. nullus amor populis nec foedera sunto. (4.622-4)

"E vós, ó Tírios, persegui com o vosso ódio a raça e toda [a descendência que dela advirá; enviai esta dádiva às minhas cinzas. Não haja amizade alguma ou alianças entre os dois povos."

A esta hostilidade dará continuidade um vingador que surgirá dos ossos da rainha (4.625), de modo a que nunca seja possível qualquer tipo de aliança entre os Cartagineses e os descendentes dos Troianos. A relaçáo entre Dido e Eneias torna-se, assim, o mito etiológico das guerras púnicas e justifica a sua inclusão numa obra que pretende ser o louvor das origens de Roma.

Dido é abandonada em favor da missão de Eneias. Roma é a rival que o afasta da rainha. É o próprio Eneias quem diz: hic amor, haec patria est, "é este o meu amor, é esta a minha pátria" (4.347). É por isso que a maldição de Dido não é só contra Eneias, mas também contra Roma.

O poder do ódio de Dido é paralelo ao poder da sua paixão. No entanto, devemos interrogar-nos acerca da origem da violência que agora exprime. Este desejo de vingança implacável é fruto do ressentimento de uma mulher abandonada, do seu orgulho ferido? Ou esta disposição para a violência faz parte da natureza da rainha, natureza que os deuses abrandaram quando Eneias chegou a Cartago? Foi o carácter de Dido, então, que justificou a manipulação divina de que foi vítima? Teria realmente massacrado os Troianos se os deuses não tivessem alterado a sua natureza, se Vénus não a tivesse ferido com o amor por Eneias? Austin 1982: ad 590 considera que é a partida de Eneias que provoca o ódio de Dido e que o Troiano não teria nada a temer da rainha, se 
tivesse ficado em Cartago. Se é certo que, enquanto permaneceu junto da rainha, esta náo demonstrou qualquer sinal de violência (ou, sequer, má-vontade...) para com Eneias e os Troianos, não devemos, no entanto, esquecer o sentimento de arrependimento que a invade quando vê Eneias partir (4.596-7): devia ter tomado esta atitude de desprezo e ódio quando entregou o poder ao herói... Mas as questóes formuladas acima permanecem sem resposta... Não é fácil determinar se a hostilidade de Dido é uma característica inata ou a consequência da rejeição.

As palavras admonitórias de Mercúrio quando, pela segunda vez, apressa a partida dos Troianos lembram a Eneias a volatilidade da natureza feminina e, consequentemente, o perigo iminente que a confiança nesta implica. Por esse motivo, seja Dido cruel por natureza ou por consequência das circunstâncias, Eneias tem de partir imediatamente, pois a sua vida corre perigo (4.560-70). Mercúrio teme que a atitude de Dido para com Eneias mude radicalmente, que ela se prepare para atacar, de alguma forma, os Troianos, já que a mulher não é um ser fiável.

Se a desilusão e as esperanças goradas que a relação com o Troiano lhe inspirara justificam uma reacção violenta, a dimensão cósmica que o anátema assume parece ultrapassar o que seria de esperar de uma mulher ultrajada. Lipking 1988: 1ss., no entanto, afirma que uma mulher abandonada é uma mulher afastada das leis, mesmo das leis da natureza... Torna-se, por isso, um ser temido pela sociedade, um ser "anti-natura" que atenta contra a vida dos outros, mesmo contra as pessoas que lhe são mais queridas - relembre-se Medeia - e contra a sua própria vida. É neste sentido que devemos entender o alcance do ódio de Dido.

Impossibilitada de exercer qualquer tipo de violência contra os Troianos, Dido lança sobre eles a crueldade do seu desejo de vingança e procede aos últimos preparativos para a sua morte (4.628ss.), incitando a velha ama de Siqueu e Ana a concluírem os sacrifícios iniciados. Lança-se então sobre a pira e, desembainhada a espada que Eneias lhe oferecera, profere as suas últimas palavras. Pacificado o ódio com que amaldiçoou os Troianos, é a mágoa de um passado dignificante que se perdeu pelo encontro com Eneias que está presente no momento da sua morte:

Felix, heu nimium felix, si litora tantum numquam Dardaniae tetigissent nostra carinae! (4.657-8) 
"Feliz! Oh! Demasiado feliz, se os navios dardânios não tivessem nunca desembarcado nas nossas praias."

Mas o desejo de vingança (ou o desgosto de não se ter vingado?) acompanha-a na morte:

\section{(...)'Moriemur inultae,}

sed moriamur' ait. 'sic, sic iunat ire sub umbras.

hauriat hunc oculis ignem crudelis ab alto

Dardanus, et nostrae secum ferat omina mortis.'(4.659-62)

"Morrerei sem vingança,

mas que eu morra - diz - é assim, é assim que me agrada

[descer para as sombras.

Que o Dardânida cruel veja do mar alto este fogo e leve consigo os presságios da minha morte."

$\mathrm{Na}$ morte da rainha, como na sua relação com Eneias, intervém o fogo que primeiro a incendiou metaforicamente e agora consome o seu corpo na pira. Mas Dido morre trespassada pela espada de Eneias e rodeada pelos objectos que este deixou: a espada (4.495), as exumiae $(4.496,4.651)$ e o leito conjugal que os acolheu a ambos $(4.496,4.648)$. Assim, Dido morre juntamente com a lembrança de Eneias, realizando na morte a união que não foi possível enquanto foi viva ${ }^{33}$.

Vénus, Cupido e o Troiano infligiram na rainha a ferida da paixão. Ela própria se fere com a espada, materializando, assim, a ferida fatal do amor. De acordo com Lyne 1987: 121, as duas imagens têm um efeito diverso. Os ferimentos suscitam simpatia, pois apresentam uma vítima em sofrimento; é Dido quem sofre, portanto é ela a vítima de quem se deve sentir piedade. A imagem do fogo, pelo contrário, é mais complexa, mais ameaçadora. O fogo da paixão de Dido transforma-se nos "fogos nefastos" (4.384) com que ameaça Eneias.

Fogo, ferida, loucura, autodestruição... É este o amor de Dido, que, literalmente, a condena e a consome. E, esgotados os argumentos, a única saída possível é a morte que a espreita desde o início.

33 Pavlock 1990: 84 refere o carácter sexual da morte de Dido que, ao trespassar-se com a espada de Eneias, materializa a derradeira relaçáo física entre ambos. Desmond 1994: 31 afirma: “(...) the destructive quality of her sexuality culminates in the phallic overtones of her death." 
Tupet 1971 analisa o facto de Dido recorrer à magia para esquecer Eneias ou para o trazer de volta e conclui que a morte da rainha é o sacrifício que as completa. No entanto, ao imolar-se na pira, Dido não é a única vítima, já que com ela é queimada a imagem de Eneias, por imposição da rainha. Este acto, que parece ter como objectivo atrair sobre Eneias forças maléficas, será a última prova do ressentimento de Dido antes do derradeiro encontro.

Quando Eneias encontra Dido nos Infernos, nos Campos das Lágrimas, entre as mulheres que morreram de amor, a atitude que ambos adoptaram no confronto que os opôs no livro 4 inverte-se. Se, em Cartago, Eneias não se alongou em respostas e explicaçóes, nos Infernos é Dido quem se recusa a falar com o Troiano e permanece impassível perante as suas palavras:

illa solo fixos oculos auersa tenebat

nec magis incepto uultum sermone mouetur,

quam si dura silex aut stet Marpesia cautes. (6.469-71)

"Ela, desviando o olhos, mantinha-os fixos no chão, e não mostra mais comoção no rosto, depois de ele ter começado

[a falar, do que uma dura pedra ou um rochedo de mármore do Marpesso."

Lipking 1988: 228 comenta assim o silêncio de Dido: “(...) as in the underworld, before a stone-faced Dido, Aeneas hears in his own excuses the lameness of the heroic mission to which he has sacrificed her. The woman's silence does not prevent her from controlling the scene." O mesmo é dizer que a reacção de Dido reflecte, como um espelho, sobre Eneias o peso e as consequências das suas acçóes. E Eneias pergunta: funeris heu tibi causa fui? "Oh! Fui eu a causa da tua morte?” (6.458). Lamenta a morte da rainha e justifica novamente a sua partida de Cartago. Impuseram-na a vontade dos deuses e a sua missão de procurar a Itália (6.45863). Como em Cartago, nos Infernos Eneias reafirma: inuitus, regina, tuo de litore cessi "foi contra a minha vontade, rainha, que me afastei das tuas praias” (6.460). Ténue consolo para quem parece ter redescoberto a paz junto de Siqueu. Recuperado o antigo amor, que pensara ter traído, a atitude impassível de Dido demonstra, no entanto, que a inimizade que as suas últimas palavras solicitaram aos deuses se mantém. Nada mudou, então, para Dido. Entre a rainha e o Troiano está tudo dito. Nada 
mais há a acrescentar. Só é necessário que Eneias saiba o que aconteceu a Dido. Impóe-se que reconheça as vítimas do seu destino, o preço da sua missão ${ }^{34}$. A dor deste encontro, causada pela indiferença de Dido, é já o começo da sua vingança.

A evolução da personagem parece evidente. No livro 1, Dido surge perante Eneias nas suas funçóes de rainha, conformada com as peripécias do seu passado e com a situação presente. De acordo com Cairns 1989: 40, o símile que compara os Cartagineses atarefados na construção da cidade a um enxame de abelhas reflecte o empenho da própria rainha. $\mathrm{O}$ interesse dos cidadáos é o espelho de um bom monarca, qualidade que faz com que Eneias simpatize com este povo e com a sua rainha. No entanto, é no espírito de Eneias que esta associação se estabelece. O Troiano admira o estatuto público de Dido e a forma como esta desempenha as suas funções.

$\mathrm{O}$ facto de Dido ser rainha amplifica as consequências da sua paixão. A forma como se deixa submeter pelos seus sentimentos faz com que esqueça os deveres que a sua posiçáo impóe. Ducos 1990: 98 comenta esta atitude de Dido como uma substituição: a rainha desaparece para dar lugar à mulher apaixonada, que pensa ter regressado à sua antiga condição de esposa. Quando Mercúrio adverte Eneias pela primeira vez, é este quem está empenhado na construçáo dos edifícios da cidade (4.260-1), ou seja, Dido cedeu ao Troiano as suas obrigaçóes. Ao abandonar Tiro, Dido trocou o seu estatuto de esposa dependente pela posição de líder. Ao assumir a sua relação com Eneias, atribui-se novamente a si própria o seu antigo papel. No entanto, esta inversão é uma transgressão do estatuto que o passado lhe impôs, estatuto enfatizado no livro 1 pelas associaçóes com Diana e Pentesileia. Dido pertence ao domínio das mulheres que, à imagem de Diana, imolaram a sua feminilidade ao poder, que assumiram uma posição normalmente reservada a homens. Quando volta a ser uma mulher dependente e alienada das funçóes que assumira, surgem o descontentamento dos seus súbditos e a hostilidade dos inimigos. Assim, a hybris de Dido é a transgressão da ordem natural do universo, o extravasar de funçóes sociais rígidas e preestabelecidas.

Acresce à estagnação dos trabalhos de fundação da cidade (4.86-9), a hostilidade crescente dos vizinhos e o ciúme de Jarbas. As maldiçóes de Dido, antes da sua morte, resultam na inimizade

${ }^{34}$ Lipking 1988: 134 comenta: "It is (...) through Dido that Aeneas learns what it means to be a Roman." 
entre Cartagineses e Romanos. Assim, as consequências políticas e históricas da paixão da rainha tornam-na ainda mais condenável, pois compromete com necessidades privadas o futuro dos interesses públicos do seu povo.

A violação do juramento de fidelidade às cinzas de Siqueu faz com que Dido incorra ainda na acusação de perjúrio. As consequências deste acto são motivo de alguma polémica. Para alguns críticos, é o juramento que condena Dido. É o facto de se comprometer perante a memória do seu defunto marido e de faltar a este juramento que obscurece a legitimidade da sua relação com Eneias ${ }^{35}$. Acresce a perda da reputação e a infracção ao pudor que lhe garantia o respeito dos inimigos. Para Horsfall 1995: 127, esta perda é um assunto grave que ultrapassa a esfera privada. O estatuto de rainha impóe a Dido uma conduta moral irrepreensível. A relação com Eneias é um atentado à sua condição de uniuira, que o autor considera actuante na condenação de Dido. Afirma ainda: "Nor could a mere consensual union ever have been enough for Augustus' distinguished ancestor" (Horsfall 1995: 128). Dido ilude-se, assim, a si própria. Desmond 1994: 29-30, pelo contrário, explica a ambiguidade da relação à luz dos costumes romanos da época de Augusto. Ainda que não se tenha realizado uma cerimónia formal, a relação entre Dido e Eneias parece ser caracterizada (pelo menos para Dido) como um matrimónio in usu, portanto, como um casamento legítimo. $\mathrm{O}$ mesmo não acontece com Eneias. Assim, deliberadamente, a união entre ambos é ambígua. Pavlock 1990: 80-1 considera que esta ambivalência é sentida pela própria Dido, que não está à vontade com a situação e, por isso, é consciente da sua culpa $(4.19,4.172)$. O amor da rainha é classificado, de forma bastante negativa, como infandus (4.85) e como furtiuus (4.171). Farron 1993: 100-2 explica o sentimento de culpa que Dido evidencia como uma forma de intensificar o pathos que domina o episódio e não como uma condenação implícita. O facto de ela se sentir culpada não quer dizer que ela deva, efectivamente, ser culpabilizada.

Náo devemos esquecer que a própria Juno presidiu ao que ela própria considerou ser um casamento legítimo. A descrição elíptica do encontro de Dido e Eneias na caverna não permite,

${ }^{35}$ Nutall 1998: 94 comenta a importância do juramento: “(...) she was false, it will be said, to the shade of her former husband Sychaeus. What is the felt weight, in the poem, of this treachery? Far less, I fancy, than that of the treachery of Aeneas to Dido." 
contudo, conclusôes sobre a legitimidade da união de ambos. O que é certo é que os acontecimentos ocorridos durante a tempestade são interpretados de modo diferente pelas partes envolvidas.

A violência e o arrependimento que, quer a rejeição de Eneias, quer o desrespeito pela memória do seu primeiro marido fazem nascer no espírito de Dido parecem ter provocado na rainha um ressentimento pétreo que a acompanha na morte. Nos Infernos, a personalidade da rainha, que em vida flutuara entre sentimentos tão díspares como castidade, amor, arrependimento e ódio, mostra apenas indiferença perante Eneias. Os conflitos e as oscilaçóes terminaram depois da morte.

A ambivalência e o conflito de valores parecem, no entanto, ser o traço mais importante do episódio. A contenda entre Eneias e Dido é também o confronto entre racionalidade e paixão, entre homem e mulher. Oliensis 1997: 303 refere a associação, na obra, do sexo feminino a estados psíquicos alterados, a sentimentos exacerbados e, portanto, destrutivos, enquanto o sexo masculino demonstra normalmente moderação e racionalidade. Assim, Dido e Eneias simbolizam o conflito entre o caos e a ordem ${ }^{36}$.

Personificam ainda a oposição entre Oriente e Ocidente, conflito caro aos contemporâneos de Virgílio. Gharbi 1990: 22 rejeita esta tese pelas origens de Eneias, também orientais. Não devemos esquecer, porém, que o Troiano é, na obra, caracterizado moralmente com valores importantes para os Romanos. No encontro com Dido, entrevê-se, por exemplo, a condenação da opulência oriental, tópico familiar aos Romanos do tempo de Virgílio desde os acontecimentos que culminaram na batalha de Áccio. Como não comparar Eneias em Cartago, vestido de púrpura, a Marco António conquistado pelos encantos de Cleópatra? E a Octaviano, quando este escapa incólume à influência nefasta da rainha e regressa a Roma, depois do suicídio desta? Seria, portanto, improvável que esta associação não fosse sentida pelos leitores da obra ${ }^{37}$.

Revê-se em Dido o fascínio e o perigo de Cleópatra, perigo que Sullivan 1992: 65 considera ser idêntico, simultaneamente, ao de Calipso, das Sereias e de Circe. Não será estranho à ambivalência

${ }^{36}$ No conflito entre caos e ordem devemos incluir a oposição entre sociedades matriarcais e sistemas patriarcais.

${ }^{37}$ Dada a importância do confronto entre Octaviano e Marco António e a influência da propaganda augustana, parece inverosímil que o próprio Virgílio desconhecesse as potencialidades do episódio, lido à luz da comparação de Dido com Cleópatra. 
intrínseca da personagem virgiliana o facto de recolher infuências literárias de origem múltipla (Homero, Apolónio de Rodes...). Se tivermos em consideração as relaçóes de semelhança que se estabelecem entre Dido e algumas personagens homéricas, nomeadamente da Odisseia, concluiremos, no seguimento de Knauer 1990: 390ss., que, em momentos diferentes do episódio, Dido retoma características de personagens tâo diversas como Circe, Alcínoo, Arete, Calipso, Polifemo ou Ájax. Os encantos de Cartago são semelhantes aos de Ogígia e de Eia. O fascínio que Dido suscita em Eneias é tão pernicioso para os objectivos do herói como os feitiços de Circe e o amor de Calipso são para o regresso de Ulisses. Também Calipso, como Dido, acusa Ulisses de trocar o certo pelo incerto. Depois de abandonada, Dido, assumindo o papel de Polifemo na Odisseia, amaldiçoa o futuro de Eneias: ainda que chegue ao seu destino, encontrará aí apenas a guerra e a infelicidade. Nos Infernos, Dido responde a Eneias como Ájax respondeu às palavras conciliadoras de Ulisses: com silêncio e indiferença.

Dido assume no destino de Eneias ora o papel de personagem adjuvante, à imagem de Alcínoo ou Arete, ora o de personagemobstáculo. McKleish 1972: 127-8 afirma que só a importância dada ao valor da pietas no episódio distingue Dido de personagens como Cila, Caríbdis e Polifemo.

A rainha assume uma importância invulgar na obra, porque a sua história e a sua caracterização se mantêm sempre ambíguas e obscuras ${ }^{38}$, suscitando ao mesmo tempo simpatia e repulsa. A ilustração mais aproximada do espírito de Dido e do seu destino é, talvez, o disfarce de Vénus, pela fusão paradoxal de características de duas divindades que são tão divergentes. A verdadeira essência de Dido, no entanto, permanece arredia, como um desafio que constantemente se renova.

${ }^{38}$ Cf. a afirmação de Hexter 1992: 336: "Vergil presents the figure of Dido from several perspectives (...) in order to frustrate any attempt on the reader' $s$ part to see her as univocal and coherent." 
Capítulo II

Dido e Ovídio: Desfazendo ambiguidades 
Ainda que Ovídio se refira a Dido, em passos mais ou menos extensos, em grande parte das suas obras, a caracterização mais completa da personagem surge na Heróide 7, uma carta endereçada por Dido a Eneias, que faz parte duma colectânea de epístolas escritas por personagens mitológicas e que se divide em duas secções: da primeira fazem parte quinze cartas escritas por personagens femininas aos respectivos amantes ou maridos que as abandonaram, da segunda constam seis cartas com a respectiva resposta.

As limitaçóes genológicas inerentes a esta obra condicionam a apreensão da personagem. Enquanto na Eneida a natureza de Dido é caracterizada quer pelos comentários do narrador, quer pelo confronto com Eneias, quer pelas suas próprias palavras e acçóes, na epístola são o discurso de Dido e o seu ponto de vista que a definem. A extensão da epopeia virgiliana e a importância nela assumida pelo episódio dos amores de Dido e Eneias permitem a exploração da personagem, desde a chegada dos Troianos a Cartago e subsequente delinear da paixão até ao encontro de Dido e Eneias nos Infernos, incluindo os vários momentos da relação de ambos e o evoluir da argumentação de um e outro. Nas Heróides encontramo-nos perante uma outra reacção da personagem aos acontecimentos relatados na Eneida. Dido re-interpreta a Eneida.

Sem a presença de Eneias ou de um narrador, é a perspectiva de Dido que se impóe. São a sua individualidade, os seus sentimentos e emoçóes que assumem na epístola o núcleo argumentativo que gera o discurso, discurso que se torna unívoco e parcial ${ }^{1}$. Enquanto tal, o tom que domina a carta é, ao mesmo tempo, incriminatório e plangente: plangente porque Dido lamenta a situação em que a partida de Eneias a deixará, incriminatório porque se considera vítima deste.

1 Watkins 1995: 31 afirma a propósito dos condicionalismos das Heróides: "From this feminine perspective, the crucial events are not the rise and fall of empires but the births, deaths, and love affairs of private individuals." 
O sentimento de rejeição que Dido experimenta faz com que Eneias seja caracterizado de forma negativa. $\mathrm{O}$ abandono produz, assim, as circunstâncias psicológicas que definem a disposiçáo com que Dido escreve. É por esta razão que a rainha aponta como principal obstáculo para o seu discurso a insensibilidade de Eneias reconhecendo, assim, desde o início, a inutilidade das suas palavras (Ep. 7.3-4). A frustraçáo do discurso e o desfecho da relação de ambos entrevê-se no símile que inicia a epístola ${ }^{2}$, que parece exprimir a ameaça velada da morte que se torna explícita nos últimos versos. A alusão ao canto do cisne antes da morte introduz uma referência ambivalente no discurso de Dido que precede a morte iminente.

A epístola desenvolve-se, deste modo, sob o signo da morte. Como o cisne, também Dido entoa o seu último canto, tornando, assim, evidente desde os primeiros versos o desfecho da sua história. Se o discurso da rainha é a última tentativa para demover Eneias de partir, nos versos 3 a 6 o desespero afirma-se como elemento condicionante desse discurso. Conhecedora da insensibilidade de Eneias, Dido tem consciência da inutilidade das suas palavras. Mas, como está habituada a perder, que importância tem dirigir mais algumas palavras ao Troiano? Palavras vâs, mero exercício de retórica ou o último desabafo de uma mente consciente da inevitabilidade da morte...

A natureza dos argumentos que a rainha utiliza, bem como a distribuição destes no discurso revelam a evolução do seu raciocínio. Se começa por invocar fundamentos lógicos para que Eneias fique em Cartago, à medida que a argumentaçáo avança apela aos sentimentos do Troiano por terceiros (por exemplo, Ascânio e os companheiros de viagem), como forma de o convencer de que é melhor para estes que ele desista do seu destino (Ep. 7.75-78, 153-162, 175-176). Por fim, pede-lhe já não que fique para sempre, mas apenas que adie a partida (Ep. 7.73-74, 178-189) e à recusa provável de Eneias contrapóe a decisão de pôr termo à vida. Na Eneida, a natureza excessiva da rainha suscita nela a ira arrebatada, desde o momento em que se apercebe de que Eneias vai partir, tornando-a, assim, incapaz de

2 Alguns editores, entre eles Bornecque 1991, consideram o símile incompleto e supóem a perda dos versos iniciais da epístola. Alguns manuscritos começam o texto desta Heróide com o dístico: Accipe, Dardanide, moriturae carmen Elissae / quae legis a nobis ultima uerba legis. "Recebe, Dardânida, o poema de Elissa moribunda. I As palavras que lês são as últimas que lerás escritas por mim.”. 
recorrer a argumentos de natureza lógica, como as vantagens de se estabelecer em Cartago.

Se atentarmos, todavia, no significado do símile inicial, o desfecho é-nos revelado ab initio, de forma mais ou menos velada, antecipando o suicídio da rainha, consequência da partida de Eneias. Por este motivo, a dualidade vítima-culpado é explorada à saciedade em todo o discurso, como um meio de suscitar piedade e/ou remorsos ao Troiano.

A característica de Eneias mais salientada por Dido é a obstinação e a indiferença que ele manifesta em relação à rainha e à situação em que a sua partida a deixará. Assim insensível, Eneias não pode ser filho de quem é. Como pode o filho de Vénus ficar indiferente perante o amor de Dido (Ep. 7.36)? Geraram-no, sem dúvida, os elementos mais hostis da natureza: os rochedos, os montes, os carvalhos inflexíveis, os animais selvagens ou o mar em fúria (Ep. 7.37-40). Como na Eneida, a caracterização da ascendência do Troiano serve o propósito de ampliar a sua natureza nociva. No livro 4, Dido, meditando de si para si nas soluçóes para a situação em que a partida de Eneias a coloca, interroga-se:

\section{Nescis heu, perdita, necdum \\ Laomedonteae sentis periuria gentis? (A. 4.541-542)}

"Ai! que não conheces, mesmo depois de te perderes, e ainda não te apercebes das falsidades da raça de Laomedonte?"

Deste modo, e ao contrário da epístola ovidiana, o carácter pouco fiável de Eneias é uma herança ancestral, deixada por Laomedonte aos Troianos ${ }^{3}$. O herói não é, assim, diferente dos seus compatriotas: é mais um perjuro numa raça de pérfidos. Mas esta afirmação vem no seguimento do confronto de Dido com o Troiano e das tentativas frustradas de Ana de demover Eneias de partir, e pouco antes de lamentar não o ter despedaçado juntamente com Ascânio (A. 4.600-602) e da maldição lançada sobre o futuro do Troiano e sobre os seus descendentes $(A$. 4.612ss.). Neste momento, a cólera desenfreada de Dido ultrapassa os limites meramente individuais. No texto ovidiano, pelo contrário, o propósito de caracterizar Eneias de forma negativa,

${ }^{3}$ Laomedonte pediu ajuda a Apolo e a Posídon para construir as muralhas de Tróia, comprometendo-se a recompensá-los pelo auxílio prestado. No entanto, depois de construídas, recusou-se a pagar o que prometera. 
aliado ao apelo aos sentimentos deste pelos seus companheiros de viagem, impede que Dido refira os antecedentes pouco louváveis dos Troianos. A argumentação baseia-se na oposição entre dois indivíduos, não entre dois povos. $\mathrm{O}$ que interessa é demonstrar que Eneias é pior do que estes, que é pior do que toda a gente, inclusive do que a raça humana. Também na Eneida, durante o confronto com Eneias, Dido nega que ele seja filho de uma deusa e que tenha uma natureza humana (A. 4.365-367). Este argumento insere-se, assim, num contexto de acusaçóes de nível pessoal e, por este motivo, é retomado na epístola. Todavia, nesta obra, a crueldade de Eneias ultrapassa a do mar e a do vento. O Troiano é pior do que eles. A sua dureza é desmesurada (Ep. 7.44).

À insensibilidade de Eneias e à decisão de partir, cujo carácter irrevogável se adivinha na repetição anafórica de certus es 'estás decidido’ (Ep. 7.7 e 9), contrapóe Dido argumentos racionais. Acusa-o de trocar o certo pelo incerto, de procurar uma terra que não sabe sequer onde fica $(E p .7 .10)$ e de, em perseguiçáo deste objectivo, pôr em perigo a sua própria vida (Ep. 7.45-46), os deuses, cuja imagem salvou da destruição de Tróia (Ep. 7.7778), e Ascânio (Ep. 7.75). Ao destino de Eneias sobrepóe a rainha as vantagens de ficar em Cartago, onde poderia assumir o poder (Ep. 7.11-12), não tendo de procurar uma terra estrangeira, por cuja posse terá de lutar, já que ninguém cederá espontaneamente as suas propriedades (Ep. 7.15-16).

Alternadamente a estes argumentos ditados pela lógica sucedem-se, a espaços, razóes emocionais que deixam entrever os sentimentos da rainha, ainda que a contiguidade entre ambos pareça funcionar como forma de dissimular as emoçóes de Dido ou de as fundamentar na lógica. É o que acontece nos versos 15 a 22. A um dístico que exprime um argumento lógico sucede outro fundamentado no amor da rainha. Assim, ao argumento da dificuldade de conseguir a posse do território que tem de procurar (Ep. 7.15-16), segue-se a afirmação de que o espera uma outra Dido que ele enganará como a enganou a ela (Ep. 7.17-18). À questão 'quando é que fundarás uma cidade como Cartago?' sucede a interrogação 'onde encontrarás uma esposa que te ame como eu?' (Ep. 7.19-22).

A intromissão da emoção na enumeração de argumentos lógicos dá lugar ao primeiro corte na argumentação: a emoção irrompe no discurso, afastando Eneias, que passa a ser referido na 
terceira pessoa do singular. À imagem da Eneida (A. 4.369ss.), este distanciamento produz no texto um efeito de isolamento, como se Dido tomasse consciência da sua situação. Williams 1971: 425 afirma a propósito da mudança de tratamento no discurso de Dido na Eneida: "(...) the distancing of her words by the use of the third person is a cold and formal indication that there can be no more dialogue between the lovers." Na epístola, Dido compreende desde o início que o diálogo inerente ao discurso epistolar é impossível entre ela e Eneias. Está sozinha. A distância de Eneias e o isolamento permitem-lhe, no entanto, dar largas à sua emotividade.

Como Virgílio, Ovídio explora a caracterização do amor da rainha como um fogo que a consome (Ep. 7.23-4). A dupla comparação amplifica o poder do amor como fogo voraz, pela acumulação de elementos associados à combustão. A referência às taedae, aos 'archotes', (Ep. 7.23) introduz no texto uma nota ambivalente importante na caracterização da relação entre Dido e Eneias: os archotes estavam presentes tanto nos cortejos nupciais ${ }^{4}$ como nas cerimónias fúnebres. Amor e morte surgem, assim, numa amálgama que insinua o desfecho próximo.

Este amor, assim poderoso e devorador como o fogo, lança-a, como ela própria reconhece, num estado psicológico anormal. Inquieta, sem dormir, só Eneias ocupa o seu espírito (Ep. 7.2526). Como na Eneida (A. 4.529-532), a sintomatologia do amor inclui a agitação emocional e a insónia. A omnipresença doentia de Eneias revela-se no poliptoto, na repetição anafórica e na posição do seu nome nos versos, na expressividade de semper inhaeret 'está sempre presente', e na hendíadis noxque quiesque 'a noite e o repouso'. A imagem de Eneias persegue-a. O tormento que a aflige entrevê-se logo na contaminação da argumentação lógica por razóes emocionais, como referimos acima. Ainda que se esforce por refutar racionalmente a decisão de Eneias, a agitação que o amor provoca na sua mente fá-la irromper em confissóes mais íntimas. No entanto, a mágoa de um amor não correspondido leva-a a pôr a nu o desconcerto do seu espírito (Ep. 7.27-30). A mágoa de ter sido abandonada por um homem ingrato e insensível levam-na a oscilar entre a vontade de náo amar e o reconhecimento doloroso da inexorabilidade da sua paixão. Ama

${ }^{4} \mathrm{Na}$ Eneida (A. 4.338-339), quando se defende das acusaçōes de perfídia de Dido, Eneias afirma: nec coniugis umquam / praetendi taedas. "nem alguma vez peguei nos archotes de esposo [i. e. nupciais]". 
quem não devia amar, quem não merece ser amado. Lamenta a infidelidade de quem ama, mas o facto de deplorar a ofensa que lhe foi feita, fá-la amar ainda mais Eneias 5 . O desequilíbrio que a rainha evidencia entre razão e paixão é acentuado pelo facto de continuar a dirigir-se a Eneias na terceira pessoa. Eneias está longe e o discurso assume o carácter de um solilóquio. Dido fala para si própria, analisa sozinha as suas emoçóes, emoçóes que se vão introduzindo no discurso mesmo quando Eneias volta a ser tratado na segunda pessoa, no momento em que o acusa de ser insensível como a natureza mais selvagem. Se a análise dos seus sentimentos provoca o afastamento de Eneias, quando o tom incriminatório regressa é necessário que ele se reaproxime.

Como referimos acima, Eneias é comparado na sua insensibilidade ao mar em fúria. No entanto, Dido explora o estado do mar de forma ambivalente: se, por um lado, o mar agitado é um obstáculo à partida de Eneias e, portanto, "aliado" da rainha, esta refere também o papel das ondas como castigo para o crime que Eneias cometeu (Ep. 7.57-60). Esta duplicidade está igualmente presente na Eneida: se, por um lado, Dido pede a Ana que suplique a Eneias que adie a viagem por causa do estado alterado das águas (A. 4.430), por outro, quando, mais tarde, perde a esperança de que Eneias fique em Cartago e se entrega à cólera, deseja que o Troiano encontre a morte no mar $(A$. 4.381-4). Na epístola de Ovídio, porém, Dido não deseja a morte de Eneias e, à mençáo da punição no mar, irrompe de novo no discurso a emoção e o tratamento do Troiano na terceira pessoa do singular (Ep. 7.61-62). Mas logo depois o naufragus hostis 'o náufrago inimigo' dá lugar a um tu que se pretende poupar à morte. A este inimigo Dido deseja a vida. Antes ele cause a morte dela do que ela a dele (Ep. 7.63-64)...

Assim demonstra Dido a sua superioridade em relação a Eneias. Ao contrário dele, Dido é incapaz de lhe desejar a morte ou o sofrimento, ainda que ele seja um ser nocivo, um criminoso permanentemente em fuga que vai deixando atrás de si toda uma série de vítimas. Dido é apenas a mais recente.

Como na Eneida, Dido lamenta a crueldade de Eneias. No entanto, na epístola, vai mais longe, pois compreende a afinidade do seu destino com o de Creúsa. $\mathrm{Na}$ epopeia virgiliana, em

${ }^{5}$ Como não recordar os versos de Catulo (72.7-8): amantem iniuria talis / cogit amare magis, sed bene uelle minus.? 'Uma ofensa assim obriga quem está apaixonado a amar mais, mas a desejar bem menos...'? 
momento algum Dido estabelece qualquer tipo de paralelismo entre a sua situação e o destino da esposa de Eneias. Na Heróide 7 , todavia, a rainha reconhece que ambas foram enganadas por Eneias (81-4). Uma e outra foram abandonadas pelo Troiano (Creúsa: Ep. 7.84; Dido: Ep. 7.7), ambas são vítimas de um homem insensível, caracterizado como durus (Ep. 7.31; 84, etc.). Deste modo, na epístola, Ovídio faz Dido analisar a narrativa da queda de Tróia. Na Eneida, apenas adivinhamos a presença da rainha enquanto Eneias relembra o passado. Náo reage à narrativa, só surge perante o leitor no livro 4, completamente deslumbrada por Eneias e pelo passado deste $(A$. 4.13-14). $\mathrm{Na}$ carta, pelo contrário, a rainha acusa Eneias do destino de Creúsa. Afirma Desmond 1994: 40 a este propósito: "Ovid's Dido implies that Aeneas's account of this scene might have proved a warning for Virgil's Dido, had she heeded its implications." Dido penitencia-se por não ter percebido o aviso que devia ter entendido na narrativa de Eneias (Ep. 7.85-6).

$\mathrm{O}$ relato da queda de Tróia na Eneida descreve o desaparecimento de Creúsa ( $A$. 2.767ss.) quando seguia atrás de Eneias, que transportava o pai aos ombros e o filho pela mão. Perkell 1992, 4a ed. analisa a relação de Eneias com Creúsa e com Dido e conclui que ambas as relaçóes terminam com a morte das mulheres, morte que é, em parte, atribuível a Eneias e ao seu destino. $\mathrm{O}$ único objectivo de Eneias é a busca do poder que os deuses lhe destinaram e que lhe é transmitido pelo casamento com Lavínia. Por isso, as mulheres que conhece antes da filha de Latino e que por ele nutrem afecto - legítimo ou ilegítimo - têm de sucumbir, para que o Troiano cumpra a sua missão. A busca da vitória é, assim, o objectivo primordial de um Eneias cruel e obcecado que atinge o cúmulo da desumanidade no episódio final da morte de Turno, desumanidade que deixara entrever, de acordo com Perkell 1992, 4a ed., na relação com Creúsa e com Dido.

Ao imaginar o seu espectro aparecendo a Eneias, Dido continua a ser identificável com Creúsa, que aparece a Eneias em Tróia, instigando-o a partir e revelando-lhe o seu futuro. Retoma também os versos 4.384 a 4.386 da Eneida:

sequar atris ignibus absens et, cum frigida mors anima seduxerit artus, omnibus umbra locis adero. 
"Mesmo ausente, seguir-te-ei com fogos nefastos e, quando a fria morte separar o meu corpo e a minha alma, como uma sombra, estarei presente em todos os lugares."

$\mathrm{Na}$ epístola, não demonstra, no entanto, a violência da ameaça de o perseguir em todos os lugares. É apenas uma imagem de sofrimento que Dido utiliza para suscitar piedade em Eneias, não terror (Ep. 7.69-70) Por esse motivo, a exploração de efeitos visuais (effusis sanguinolenta comis 'ensanguentada e de cabelos desgrenhados') e psicológicos (deceptae 'enganada'; tristis 'triste') assume especial importância na argumentação, já que (como Creúsa) Dido prevê o futuro e apresenta a Eneias o que será a consequência da partida, fá-lo visualizar o que acontecerá se ele deixar Cartago. Assim, na apresentação da condição de Dido postmortem, ainda que com as devidas limitaçóes, Ovídio aproxima-a mais da ternura de Creúsa do que da cólera desenfreada que demonstra na Eneida.

Também a relação de Dido com Ascânio é apresentada de modo diferente na epístola. $\mathrm{Na}$ Eneida, a ira da rainha vira-se contra pai e filho, e Dido chega a desejar ter despedaçado Ascânio e tê-lo servido num banquete ao próprio pai (A. 4.601-602). $\mathrm{Na}$ Heróide 7, pelo contrário, Dido não deseja fazer nem lamenta náo ter feito qualquer tipo de mal ao filho de Eneias. A atitude da rainha para com Ascânio retoma a ternura que por ele nutria antes de o Troiano ter decidido partir. Em nenhuma ocasião Dido transfere para Ascânio a ira suscitada pelo abandono, porque considera o filho de Eneias mais uma das vítimas do Troiano. Devemos supor, portanto, que o instinto maternal, que Vénus e Cupido exploraram na epopeia virgiliana, não se desvaneceu com a rejeição que Dido sofreu. Pelo contrário, a necessidade de ser mãe continua actuante na relação da rainha com Ascânio e materializa-se na acusação que faz a Eneias de a abandonar grávida. Assim, o que na Eneida não passa de um lamento $(A$. 4.327-330) ganha foros de realidade na epístola:

forsitan et grauidam Dido, scelerate, relinquas

parsque tui lateat corpore clausa meo.

accedet fatis matris miserabilis infans

et nondum nato funeris auctor eris,

cumque parente sua frater morietur Iuli,

poenaque conexos auferet una duos. (Ep. 7.133-8) 
"Talvez abandones até, criminoso, Dido grávida e parte de ti se esconda, fechada, no meu corpo. A triste criança juntar-se-á ao destino da mãe e tu serás o responsável pela sua morte, mesmo antes de ter nascido. Com a sua mãe morrerá o irmão de Julo, e um mesmo castigo levar-nos-á a ambos, unidos um ao outro."

Se na epopeia virgiliana Dido revela um pouco da sua natureza humana, na carta, ao consubstanciar o desejo de ser máe na hipótese de uma gravidez, afasta-se da sua dignidade de rainha. Ainda que na Eneida se possa entender este desejo como resposta à necessidade de sucessão, na epístola o filho não nascido é apenas mais um argumento que Dido utiliza para que Eneias fique, já que em nenhum momento exprime preocupação pelo seu povo. $\mathrm{Na}$ obra de Ovídio não temos a rainha Dido, temos a outra Dido, aquela que não em parte do seu ser - parafraseando Jenkyns 1996: 57-8 -, mas na totalidade da sua essência exprime sentimentos e fraquezas humanas. Dido explora a afectividade de Eneias, ao mesmo tempo que vai aumentando o número de vítimas do Troiano: ela, Creúsa, Ascânio... mas também esta criança que não nascerá, que é parte de um pai que é culpado pela morte da mãe (scelerate 'criminoso'...). Note-se a perífrase que designa a criança: frater... Iuli ‘o irmão de Julo’ (Ep. 7.137). A exploração do parentesco demonstra as intençôes de Dido, que utiliza caminhos ínvios para pôr em causa a autenticidade do comportamento de Eneias em relação às suas obrigaçóes familiares e à pietas de que este é uma espécie de personificação.

Watkins 1995: 33 comenta deste modo as implicações da hipótese da gravidez e posterior morte de Dido juntamente com o seu filho: "Dido's emphasis on Aeneas' disregard for her and her unborn child arises from a private, feminine perception of experience that defies the Aeneid's celebration of history as an unbroken, patriarchal succession." Os valores patriarcais ilustrados na prefiguração da fuga de Eneias de Tróia, com Ascânio pela mão e Anquises ao ombro e transportando as imagens dos deuses, são postos em causa por Dido (Ep. 7.79-81). Se Eneias é capaz de a abandonar, mesmo considerando a hipótese de estar grávida, demonstrando, assim, uma crueldade ímpar, é porque as virtuosas façanhas que ele lhe contara não aconteceram realmente.

A gravidez, é, assim, mais um elemento que segue o propósito de caracterizar Eneias de forma negativa. $\mathrm{O}$ instinto maternal de Dido toma, deste modo, forma e é realçado também pela 
preocupação que demonstra por Ascânio. Ambos os elementos, no entanto, têm como finalidade tornar Dido mais humana e Eneias mais cruel. O objectivo da argumentação da rainha é provar que ela é vítima de um criminoso da pior espécie.

Nem os deuses venerados por Eneias desconhecem a natureza perniciosa do Troiano. Dido destrói completamente a imagem virgiliana do pius Aeneas, substituindo-a pelo seu oposto (Ep. 7.12932). A missão e a protecção divina de Eneias são desvalorizadas por Dido, que considera um castigo as viagens do Troiano em perseguição do seu destino (Ep. 7.87-8). O sarcasmo com que Dido se refere à alegação de Eneias de que segue prescriçôes divinas $(E p$. 7.139-40) e o descrédito inerente à interrogação dos versos 141 a 142 subvertem a importância que na Eneida assume a intervenção dos deuses em prol de Eneias e da sua missão. Dido não acredita na inexorabilidade da missão daquele. É por isso que enumera a Eneias as vantagens de, em vez de partir pelo mar agitado em busca de uma terra desconhecida, ficar em Cartago e aí fundar uma nova Tróia (Ep. 7.143-62). O acumular destes argumentos resulta na conclusão de que Eneias não tem razôes, nem lícitas, nem convincentes, para partir. Ao menosprezar a premência da missão de Eneias, Dido desacredita as razóes que na Eneida causam e justificam o seu abandono (Desmond 1994: 41-2). Na obra de Virgílio, a fatalidade da morte da rainha é provocada pela incapacidade de interpretar a narrativa de Eneias nos livros 2 e 3 e as implicaçóes do destino deste. É necessário que Dido não compreenda a inevitabilidade da partida, que, com a ajuda de Ana, se iluda com a esperança de um casamento próspero. $\mathrm{Na}$ Heróide 7 , pelo contrário, Dido mostra-se mais esclarecida na forma como analisa as circunstâncias da partida de Eneias. Reconhece desde o início da epístola que os deuses ou, pelo menos, um deles não está do seu lado (Ep. 7.4). Parece, assim, identificar ou sentir a conspiração de Vénus e Cupido narrada na Eneida.

Ironicamente, porém, é a estes deuses que causaram a sua perda que Dido pede ajuda (Ep. 7.31-2). É que, na Heróide 7, Vénus e Cupido não são para a rainha as entidades conspiradoras e intangíveis da Eneida. A exploração dos graus de parentesco aproxima estas divindades de Dido, que se considera nora de Vénus. Ela demonstra, assim, o entendimento que tem da sua relação com Eneias, que reconhece como legítima (Knox 1995: 
ad 31). Dido considera-se 'esposa' (Ep. 7.69) - do Troiano'.

A natureza nociva do encontro de ambos é reconhecida por Dido, que lamenta a ruína da sua reputação 7 . A descrição da união de ambos na caverna é, todavia, e à imagem da Eneida, elíptica ${ }^{8}$. No entanto, o facto de ser Dido a relatar o que aconteceu substitui a perspectiva do narrador da epopeia pela da personagem, e não apenas no momento em que se deu o encontro com Eneias, mas também no momento presente, em que Dido reanalisa o que aconteceu (93-6). Enquanto na Eneida as divindades que presidiram à união são identificadas pelo narrador como a Terra e Juno ( $A$. 4.166) e as ninfas uivando, na epístola Dido reconhece, ou melhor, julga ter reconhecido, apenas estas últimas. Interpretando, todavia, os acontecimentos retrospectivamente, percebe agora que não eram as ninfas, mas as Euménides, que indicavam o seu destino ${ }^{9}$. A presença destas como testemunhas da união dá continuidade a uma série de referências à morte que têm início no símile do canto do cisne. As divindades que presidiram ao casamento de ambos são indício do fim trágico provocado pela consumação de um amor ilícito. Ilícito porque uma das partes enganou de forma perversa e consciente a outra. Talvez por isso mesmo Dido se recorde de Siqueu e descreva o episódio também referido na Eneida (A.4.457-61) da noite em que ouviu a voz do marido, chamando-a (Ep. 7.99-102). Afastando-se novamente de Eneias, que é substituído, enquanto destinatário do discurso, pelo defunto marido de Dido, esta empreende, perante a lembrança de Siqueu, a defesa da sua conduta. De facto, Dido não se considera

${ }^{6}$ Dörrie, citado em Jakobson 1974: 85, n. 20, considera que o fantasma que Dido descreve na carta náo é o seu, mas o de Creúsa e que, consequentemente, coniugis se refere à esposa troiana de Eneias. Jakobson discorda. Também Knox 1995 ad loc. não tem dúvidas na identificação do fantasma de Dido.

${ }^{7}$ Em Ep. 7.92, Dido utiliza a palavra concubitus (relação de natureza carnal) para designar a relação com Eneias. Cf. Ernout-Meillet 1994, 4a ed.: s. v. "cubo". Também no verso 103 se diz esposa (coniunx) de Siqueu, a quem, no verso 128 designa como marido (uiri), como se, apesar de toda a argumentação desenvolvida, tivesse consciência de que a única ligação legítima que mantivera fora com Siqueu.

${ }^{8}$ Nos Tristia 2.530 ss., Ovídio refere-se à receptividade do livro 4 da Eneida e afirma: non legitur pars ulla de corpore toto, I quam non legitimo foedere iunctus amor. "nenhuma secçáo do livro se lê como a que trata de um amor alicerçado numa uniáo náo legítima", classificando, assim, de forma clara, a natureza da ligação entre Dido e Eneias.

${ }^{9} \mathrm{~A}$ referência às Euménides retoma o símile que na Eneida (A. 4.469-70) compara Dido a Penteu perseguido por aquelas divindades. 
inocente, mas vítima de Eneias (Ep. 7.105-6). Foi ele quem a enganou, por isso ele é mais culpado do que ela. Ainda assim, Dido entende que cometeu uma ofensa às cinzas de Siqueu (Ep. 7.98).

Poder-se-ia concluir que, como na Eneida (A. 4.552), Dido lamenta não ter permanecido fiel a Siqueu. No entanto, a lembrança de Siqueu rapidamente se desvanece na defesa da sua conduta e na recordação das peripécias que a morte daquele provocou na vida de Dido, vítima de Eneias, mas também, de certa forma, vítima da morte de Siqueu, circunstância que a obrigou a desempenhar um papel para o qual não estava preparada (cf. rudis 'sem experiência', Ep. 7.122). A chegada de Eneias e a esperança de ter um marido legítimo $(E p .7 .108)$, aliadas à acção enganadora deste, fizeram com que Dido acreditasse que a unia ao Troiano um vínculo autêntico.

É por esta razão que, ao romper o compromisso que o unira a Dido, Eneias incorre na acusação de perfídia (Ep. 7.8-9, 17-18, $32,57-58,118)$. O número de ocorrências demonstra o valor dado ao carácter perjuro de Eneias. Este tópico retoma a denúncia que Dido faz na epopeia virgiliana (A. 4.305ss.), quando se apercebe de que Eneias vai partir em segredo e se dirige a ele chamando-o 'pérfido' $(A$. 4.305), repetido quando nega que ele tenha uma natureza humana ou divina $(A .4 .366)$. Ao recomendar a Ana que se dirija ao Troiano e lhe peça para adiar a partida, refere-se a Eneias de forma dolorosa como perfide ille 'aquele pérfido' $(A$. 4.421), evitando pronunciar o seu nome. No entanto, Ovídio amplifica a acusação de perfídia, de modo a explorar de forma mais sistemática a dualidade entre vítima e culpado. Foi Eneias quem enganou a rainha. Ela, na sua credulidade, iludida pela segurança que a ascendência de Eneias lhe garantia, deixou-se seduzir pela esperança de um casamento legítimo (Ep. 7.107-8).

Inocente e enganada, é assim que Dido se apresenta. Depois de Creúsa, é dela que Eneias foge. A constatação deste facto provoca em Dido um sentimento de mágoa que se vai revelando em vários momentos da epístola, nomeadamente no reconhecimento doloroso de que Eneias prefere morrer nas águas agitadas a ficar com ela em Cartago (Ep. 7.45-8). Também esta tristeza é uma forma de convencer Eneias a ficar, é um argumento que serve para suscitar misericórdia no Troiano. A disseminação de referências à sua morte tem a mesma finalidade: caracterizá-la como vítima de Eneias (Ep. 7.68). 
A recordação do seu passado heróico é outra forma de mostrar a Eneias que uma mulher como ela não merece ser abandonada. Jakobson 1974: 80, analisando as diferenças do passado de Dido tal como ela o descreve na Heróide e na Eneida, comenta: "We have here [i. e. na Heróide 7] no dux femina facti." Esta enumeração das suas façanhas não tem a grandeza da Eneida porque, na epístola, Dido não abdica de enfatizar a sua fragilidade enquanto mulher (Ep. 7.121). Também as referências a Eneias (Ep. 7.118, 124) que vai introduzindo na analepse - estabelecendo, deste modo, a noção de continuidade entre passado e presente -, diluem o carácter heróico do seu passado. Realçam, no entanto, a permanência dos infortúnios na sua vida. É que Dido continua a desenvolver a perspectiva de que, na relação com o Troiano, é ela a vítima, é ela quem sofre as consequências da índole nociva deste. Eneias, por seu lado, é o culpado. É esta dualidade, inerente a todo o discurso, que Dido explora, mesmo quando refere os "mil pretendentes" (Ep. 7.123). A hipérbole é uma forma de se valorizar perante os olhos de Eneias e de despertar nele o ciúme, enquanto, simultaneamente, o designa de forma depreciativa por "um indivíduo qualquer" (Ep. 7.124). É também um expediente para demonstrar a Eneias que, ainda que ele a tenha desprezado, agradou a muitos pretendentes que náo aceitaram de forma passiva o facto de terem sido preteridos. Jakobson 1974: 80 nota ainda que, na Eneida, quando Eneias chegou a Cartago, Dido já tinha rejeitado as ofertas de casamento por parte de Jarbas e dos outros chefes africanos. A modificação deste tema na epístola de Ovídio tem como objectivo reforçar a dualidade referida acima. É que, para Dido, Eneias é, agora, o culpado de todos os seus males. O que interessa não é retratar a majestade das suas acçôes enquanto rainha. É enfatizar a infelicidade que marcou a sua vida e a responsabilidade de Eneias.

À medida que o fim da argumentação se aproxima, Dido, depois de mais uma vez lembrar a Eneias as vantagens de cumprir em Cartago o seu destino, retoma o tom de súplica e a mágoa que evidenciara antes. Abandonando a pretensão de um casamento legítimo, declara-se inocente de outro crime que não o de ter amado Eneias (Ep. 7.164). O seu crime foi, assim, um sentimento generoso que a ele só trouxe vantagens. A estranheza de Dido perante a atitude obstinada e fria de Eneias em relação a ela levam-na a afirmar que nem ela nem a sua família foram alguma vez inimigos de Eneias (Ep. 7.165-6). Pelo contrário, a 
dimensão do amor que por ele sente é tal que suportaria amá-lo sem ser correspondida, abdicando de qualquer tipo de ligação legítima e da sua própria dignidade, contanto que continuasse a ser dele, a estar unida a ele por qualquer tipo de relaçáo $(E p$. 7.167-8). Também já não pede que Eneias fique em Cartago para sempre, mas que fique apenas o tempo necessário para ter uma viagem segura (Ep. 7.169 ss.), tempo que a ensinaria a suportar a tristeza provocada pela ausência do $\operatorname{Troiano}^{10}$ (Ep. 7.177-80).

Desalento e abdicação dão lugar à resignação. Se nenhum dos argumentos exaustivamente apresentados persuadem Eneias a ficar, se nem a iminência da morte de Dido, insinuada ao longo do discurso, demovem Eneias de partir, então a decisão de morrer é irrevogável (Ep. 7.181-2). Terminada a argumentação, que se revelou infrutífera, como Dido afirmara nos primeiros versos, numa estrutura estranhamente circular, o discurso regressa à ideia da morte que se apresentara no símile do cisne. Porque entende ter sido uma vítima inocente da crueldade de Eneias, Dido utiliza a descrição da sua imagem enquanto escreve ${ }^{11}$ ou como mais uma forma de suscitar a compaixão de Eneias ou como uma punição para o Troiano (Ep. 7.183-6). O pormenor com que descreve a espada troiana, presente de Eneias, como se descrevesse um quadro, causa horror e misericórdia para com a rainha. A substituição das lágrimas pelo sangue acentua a culpa de Eneias. É notável a caracterização da espada: primeiro, identificada como Troicus ensis 'a espada troiana' (Ep. 7.184), para que não haja dúvidas de que é com a espada que Eneias lhe ofereceu que Dido vai pôr fim à vida; por último, strictum... ensem 'a espada... desembainhada' (Ep. 7.185), a mostrar que a espada está já preparada para desempenhar o seu papel na morte da rainha, provando a iminência do fim ${ }^{12}$.

${ }^{10}$ Argumento já presente na Eneida (A. 4.430ss.): exspectet facilemque fugam uentosque ferentis / (...) tempus inane peto, requiem spatiumque furori, I dum me mea uictam doceat fortuna dolere. "que ele aguarde uma viagem fácil e ventos favoráveis / (...) peço um pouco mais de tempo, para que a minha paixão tenha tempo para repousar, até que a minha sorte me ensine, a mim que me dou por vencida, a suportar a dor."

${ }^{11}$ Recorde-se a utilização da imagem como forma de persuasão nos versos Ep. 7.69 ss..

12 Também em Amores 2.18.25-6 Ovídio se refere à carta de Dido como: quodque tenens strictum Dido miserabilis ensem / dicat. "o que Dido, desgraçada, com a espada desembainhada na mão / diz". A forma como designa a epístola cristaliza o momento da morte da rainha, recorrendo à descrição do seu aspecto enquanto escreve e segura a espada desembainhada. Assim, através 
Ao ser trespassada pela espada de Eneias, Dido reconhece a materialização da ferida metafórica do seu amor pelo herói (Ep. 7.189-90) e explora, ao mesmo tempo, a caracterização da paixão como uma ferida, que Virgílio desenvolvera na Eneida. No entanto, mais uma vez, em Ovídio, Dido é mais perspicaz, percebe o que só o leitor percebe na Eneida (Desmond 1994: 43).

De acordo com Khan 1965: 284, a questão da espada, que alguns críticos consideram irrelevante na Eneida, ganha em dramatismo na Heróide 7, já que, descrevendo a espada no seu regaço, Dido insinua não só a sua morte, mas também a morte da criança que carregaria no seu ventre. Fazendo isto, Dido não pretenderia, segundo o mesmo autor, transformar-se em Medeia, mas aumentar a culpa de Eneias. De facto, o risco de ser considerada uma heroína vingativa e cruel à imagem de Medeia dilui-se na epístola porque a gravidez de Dido é tão-só uma hipótese, é apenas mais uma forma de caracterizar Eneias como um ser cruel e insensível.

Acresce a ausência de alusôes ao sentimento de vingança, tornando, desta forma, Dido mais suave, mais terna. De acordo com Knox 1995: ad 29, ao afirmar que não odeia Eneias (Ep. 7.29-30), Dido rejeita a maldição que profere na Eneida (A. 4.607-29). De facto, a violência das imprecaçóes de Dido contra Eneias é substituída na Heróide 7 por acusações de perfídia e de crueldade. A violência da reacção de Dido a estas acusaçóes é, no entanto, virada exclusivamente para si própria (Ep. 7.63-4). Watkins 1995: 32 comenta desta forma a diferença, a este nível, entre as duas obras: "Ovid increases our sympathy for Dido by suppressing the vindictiveness that characterizes her in the Aeneid. There her Euripidean fury reinforces Virgil's portrayal of love as dangerously volatile." De facto, e apesar de também na epístola a rainha manifestar alguma agitação psicológica, esta não atinge a dimensão do furor que a caracteriza na Eneida. A demência que condiciona a sua conduta naquela obra é substituída no texto de Ovídio pela ideia tantas vezes repetida da força da sua paixão ${ }^{13}$.

da evocação dos últimos versos da epístola, Ovídio designa todo o texto. Neste poema dos Amores Ovídio justifica a opção por géneros menores em detrimento da tragédia e da épica. Enquanto explica a intervenção divina nesta escolha, introduz, como faz em outras situaçóes, ecos das Heroidum Epistulae, estabelecendo uma espécie de interrelação textual entre as suas obras e testando o conhecimento do leitor.

13 Não é despiciendo o facto de, por razōes genológicas, o relato na 
Mesmo a má vontade e o tom incriminatório com que, a espaços, se dirige a Eneias são rapidamente atenuados pelo amor e pela preocupação que manifesta pelos entes queridos deste (Ascânio, as cinzas de Anquises...), pelos companheiros de viagem, pelas imagens dos deuses e por ele próprio. Dido nunca deseja a morte a Eneias ou aos seres que lhe estão próximos. Pelo contrário, utiliza o bem-estar destes como argumento para que Eneias permaneça em Cartago.

Por este motivo, a sua morte é um assunto privado que só diz respeito a ela, a Eneias, que é o culpado, e a Ana que aparece apenas nos últimos versos da carta e que desempenha o papel do familiar que procederá às cerimónias fúnebres. Ao renunciar à sua identificação como esposa de Siqueu (Ep. 7.193), Dido suprime o seu passado glorioso, não pretende ser recordada como a mulher fenícia que, fugindo do irmão criminoso, fundou uma cidade grandiosa. O seu papel de rainha dilui-se no momento da morte.

Enquanto na epopeia virgiliana Dido lança sobre os descendentes de Eneias e dos Cartagineses uma maldição que há-de materializar-se na inimizade permanente entre os dois povos, na Heróide apenas interessa eternizar a dualidade vítimaculpado, apenas interessa cristalizar a acusaçáo que pretende que se inscreva no seu epitáfio:

praebuit aeneas et causam mortis et ensem.

ipsa sua Dido concidit usa manu. (Ep. 7.195-6)

"Eneias ofereceu a causa da morte e a espada.

a própria Dido caiu usando a sua mão"

De forma inequívoca, sem ambiguidades, Dido reduz a complexidade da relaçáo causa-efeito inerente à sua morte, na Eneida. Eneias é culpado, duplamente culpado, já que, além de ter causado, com a sua partida, o suicídio da rainha, foi ele quem ofereceu a espada com que ela se vai trespassar. A única coisa que ele não fez foi desferir o golpe final. As circunstâncias da sua morte, Dido deixa-as bem definidas. É este o seu testamento para a posteridade: que se saiba quem foi o criminoso que a matou.

primeira pessoa poder omitir sinais de loucura que seriam reconhecíveis por um narrador omnisciente. No entanto, a ausência da caracterização negativa da loucura dá continuidade ao tom geral do poema, inocentando Dido das palavras mais hostis que profere na Eneida. 
Assim, o epitáfio é uma espécie de vingança e substitui o vingador que Dido prevê na Eneida (A. 4.625).

A permanência da acusação inerente ao epitáfio reinterpreta, de acordo com Desmond 1994: 38, a narrativa da epopeia virgiliana. De facto, não só o epitáfio, mas toda a argumentação que Dido desenvolve ao longo do seu discurso testemunha a existência de um Eneias que é culpado não só da morte de Dido, mas de uma série de faltas que o afastam do pius Aeneas da Eneida. Dido acusa-o de ser culpado da morte de Creúsa, de arriscar a vida e o bem-estar dos que o seguiram desde Tróia (Ascânio, os companheiros de viagem, as imagens dos deuses...).

Assim, ainda que a caracterização de Dido na Eneida seja ambígua e permita várias leituras, Ovídio manifesta de forma inequívoca uma interpretação pessimista e/ou redutora do episódio. Reduzindo a importância do destino e desconfiando da pietas de Eneias, apresenta o abandono de Dido como uma traição injustificável. A missão fundadora de Eneias perde na epístola a dimensão que lhe é conferida na Eneida e que fundamenta o abandono da rainha.

O breve resumo do episódio que integra as Metamorfoses dá continuidade a esta interpretação da Eneida:

Excipit Aenean illic animoque domoque

non bene discidium Phrygii latura mariti

Sidonis; inque pyra sacri sub imagine facta

incubuit ferro deceptaque decepit omnes. (Met. 14.78-81)

"A Sidónia acolheu Eneias no seu coração e na sua casa ela, que não haveria de suportar a separação do marido frígio. Numa pira que mandou construir sob o pretexto falso de fazer

[um sacrifício

lançou-se sobre a espada e, depois de ter sido enganada, foi ela [quem enganou todos."

Dido foi enganada por Eneias que, depois de a ter deixado, fugiu de Cartago:

(...) rursus harenosae fugiens noua moenia terrae (...)(Met. 14.82)

“(...) escapando de novo das muralhas recém-construídas na [terra arenosa." 
Watkins 1995: 33 comenta do seguinte modo a inclusão, ainda que breve, do episódio nas Metamorfoses: "By positing mutability as the fundamental ground of history, Ovid insists that the imperium for which Dido suffers is not a final, perfect, and enduring state. It constitutes simply one more episode in the ongoing cycles of human experiences." Como nas Heróides, a redução da importância do destino de Eneias, pelo qual Dido tem de ser abandonada, obscurece as intençôes do Troiano. Enfraquecendo a magnitude da missão de Eneias, a partida deste assume o carácter de um acto de ingratidáo e crueldade para com Dido, que o acolheu e ajudou num momento difícil. Não suportando o afastamento de Eneias, Dido pôs termo à sua vida sobre a pira e trespassando-se com a espada. É de notar que a referência a Dido não por nenhum dos seus nomes, mas apenas pela sua origem, se insere no resumo da história de Eneias, o que demonstra uma espécie de mudança de ponto de vista. De facto, neste excerto das Metamorfoses é Eneias quem é a personagem principal, é nele que se centra a narrativa. No entanto, a perspectiva de Ovídio continua a ser a mesma. A dualidade explorada na epístola mantém-se: Dido é vítima do Troiano e do seu destino.

$\mathrm{Na}$ Arte de Amar e nos Remédios de Amor, Ovídio enumera Dido entre as heroínas míticas que não souberam amar e que, por esta razão, tiveram um fim trágico.

Et famam pietatis habet, tamen hospes et ensem praebuit et causam mortis, Elissa, tuae.

quid uos perdiderit, dicam: nescistis amare;

defuit ars uobis; arte perennat amor. (Ars 3.39-42)

“Tem até a fama de ser pio, no entanto o hóspede ofereceu a espada e a causa, Elissa, da tua morte.

Dir-vos-ei o que causou a vossa ruína: não soubestes amar, faltou-vos a arte; é com a arte que se prolonga o amor."

\section{(...) si me foret usa magistro, (...)}

nec moriens Dido summa uidisset ab arce

Dardanias uento uela dedisse rates. (Rem. 55, 57-8)

"Se tivesse recorrido a mim como mestre (...)

Dido, moribunda, não teria visto do alto da cidadela que as naus dardânias tinham enfunado as velas com o vento." 
Denominador comum das referências a Dido na obra de Ovídio é o momento da sua morte. Na Arte de Amar, reproduz em parte o epitáfio que termina a Heróide 7, aludindo ainda à caracterização de Eneias como pius ${ }^{14}$. Deste modo, Ovídio explora a dualidade inerente à relação do Troiano com Dido. Na Heróide 7, dá voz à perspectiva de Dido acerca dessa relação. Nas outras obras, limita-se a referir brevemente um ou outro elemento do episódio, sendo o mais frequente a morte da rainha. O vector mais marcante da sua história parece ser, assim, o suicídio. No entanto, a referência a Dido nestas duas obras assume também um carácter didáctico, já que é referida como exemplo da falta das orientaçóes que Ovídio se propóe dar. De facto, se Dido tivesse usufruído dos ensinamentos veiculados nestas obras, ou não teria sido abandonada por Eneias ou, se tal tivesse acontecido, os Remédios de Amor tê-la-iam ensinado a esquecer a paixão e a continuar a viver. Esta nova perspectiva que apresenta Dido como alguém que não soube amar correctamente e que, posteriormente, não soube ultrapassar a paixão, serve o objectivo de demonstrar que, de facto, o amor é uma ars que deve ser ensinada e aprendida.

No livro 3 dos Fastos, a história de Ana Perena, que Ovídio identifica com a irmá de Dido, descreve os acontecimentos posteriores à morte da rainha, quando Jarbas invadiu o palácio, obrigando Ana a fugir de Cartago. As referências a Dido nesta obra seguem os elementos explorados nas obras analisadas. $\mathrm{O}$ resumo da história de Dido é relevante pela sua simplicidade:

Arserat Aeneae Dido miserabilis igne, arserat exstructis in sua fata rogis, compositusque cinis, tumulique in marmore carmen hoc breue, quod moriens ipsa reliquit, erat: praebvit Aeneas et cavsam mortis et ensem: ipsa sva Dido concidit vsa manu. (Fast. 3.545-50)

“Tinha sido consumida a pobre Dido no fogo do amor a Eneias tinha sido consumida na pira construida para [cumprir o destino, e recolhidas as cinzas, no mármore do túmulo inscreveu-se apenas este pequeno epitáfio que ela própria deixou no [momento da morte:

14 Caracterização também presente em Amores 2.18.31, referindo-se às respostas que o seu amigo Sabino compôs para algumas das Heróides: iam pius Aeneas miserae rescripsit Elissae. "já o pio Eneias escreveu em resposta a Elissa." 
"Eneias ofereceu a causa da morte e a espada.

a própria Dido caiu usando a sua mão.”

Está circunscrito à paixão por Eneias e à morte na pira, ambas as acçôes definidas pela repetição anafórica da mesma forma verbal - arserat 'tinha sido consumida pelo fogo' (Fast. 3.545-6) -, denotando o valor ambivalente do fogo no episódio. É de realçar também a reprodução do epitáfio da Heróide 7 , ipsis uerbis, produzindo, deste modo, a condensação da história de Dido no momento da sua morte. Ovídio continua a desenvolver a temática do suicídio de Dido. Segue-se a descrição da fuga de Ana de Cartago, não sem antes proceder às cerimónias fúnebres em honra da irmã. A história de Ana Perena é, assim, a narração dos acontecimentos que se seguiram à morte de Dido, enquanto a Heróide é a reprodução dos pensamentos da rainha antes do suicídio. Nos últimos versos da carta de Dido, esta dirigia-se à irmã:

Anna soror, soror Anna, meae male conscia culpae, iam dabis in cineres ultima dona meos. (Ep. 7.191-2)

"Ana minha irmã, minha irmã Ana, infelizmente cúmplice da darás em breve os últimos dons às minhas cinzas.”

[minha culpa,

Nos Fastos (3.559-64), Ovídio descreve os ultima dona que Ana prestou às cinzas de Dido. Atentemos no facto de Ana se referir às muralhas de Cartago como as sororia (...) / moenia (Fast. 3.559-60) e dulce sororis opus (Fast. 3.566), salientando, deste modo, o papel de Dido como fundadora de Cartago.

Depois de algumas peripécias, Ana desembarca no Lácio, após uma tempestade que deixou à deriva a embarcação em que viajava. Aí Eneias, acompanhado por Acates, avista Ana. Quando esta o vê, atemorizada, fica sem saber o que fazer:

Heu, quid agat? fugiat? quos terrae quaerat hiatus?

ante oculos miserae fata sororis erant. (Fast. 3.609-10)

"Que fazer? Haveria de fugir? Que abismos da terra procuraria? Estava à frente dos seus olhos o destino da pobre irmã." 
A recordação do destino da irmã fá-la temer Eneias: parece que a argumentação de Dido convenceu Ana, que, agora, teme o Troiano. Mas este, chorando, comovido pela recordação da rainha (Fast. 3.612) empreende a defesa que lhe é negada na Heróide 7. Reafirmando a premência do seu destino (Fast. 3.61316), garante a Ana que nunca desconfiou de que Dido seria capaz de pôr fim à vida (Fast. 3.617-18) e recorda de forma muito breve o encontro de ambos nos Infernos, sem referir, no entanto, a atitude de Dido perante as palavras que entâo lhe dirigiu (Fast. 3.619-20). Náo deixa de ser curiosa a referência às "feridas que não são dignas daquele corpo", feridas físicas que não foram senão a materialização da causa da morte de Dido. No entanto, pela atitude que toma em relação a Ana, protegendo-a numa derradeira prova de gratidão para com Dido (Fast. 3.623), Eneias parece redimir-se das suas faltas. Todavia, ao confiar Ana a Lavínia, esta, inflamada pelo ciúme, conspira contra a irmã de Dido. A mulher prometida a Eneias pelo destino conspira contra Ana como o espírito de missáo conspirara contra Dido. Mas o fantasma desta aparece a meio da noite a Ana, alertando-a para os perigos em que incorre, se permanecer junto de Eneias:

\section{Nox erat: ante torum uisa est adstare sororis squalenti Dido sanguinulenta coma et 'fuge, ne dubita, maestum fuge' dicere 'tectum'. (Fast. 3.639-41) \\ "Era noite: viu-se à frente do leito da irmã, em pé, Dido, coberta de sangue, com os cabelos em desalinho e que dizia: 'Foge sem hesitar, foge desta casa sinistra'.}

A descrição do fantasma de Dido é identificável com a imagem que ela própria apresentara a Eneias nos versos 69 a 70 da Heróide 7.

Dido evita, assim, que a irmã seja também sacrificada pelo símbolo da missão de Eneias. Ana tem de se afastar do Troiano e da sua casa porque não há convivência possível entre os dois povos. Não há perdão para Eneias. Ao escolher o seu destino, do qual Lavínia é uma personificação, Eneias destruiu todas as possibilidades de ser absolvido do crime de ter causado a morte de Dido. A acusação do epitáfio mantém-se. Eneias continua a ser culpado e Dido a sua vítima.

Deste modo, Ovídio reduz a complexidade do episódio na Eneida e adopta uma perspectiva favorável à rainha. Este processo de simplificação é fomentado pela natureza diferente das duas 
obras e, antes de mais, pelas características e vivências divergentes dos dois autores. $\mathrm{Na}$ Eneida, o encontro de Eneias com Dido é apenas um dos momentos da narrativa épica, é apenas uma prova (difícil) que o Troiano tem de vencer para cumprir o seu destino. O objectivo de fundar Roma tem de superar todos os obstáculos, demonstrando que valores como a pátria ou a pietas têm de se sobrepor às paixões e aos desejos individuais. A glorificação destes princípios ecoa o contexto em que a epopeia virgiliana foi composta. Após um longo período de guerras civis e de instabilidade política, Octaviano surge como um redentor. Ao recuperar a lenda de Eneias como antepassado da Gens Iulia e como a prefiguração de ideais caros ao futuro princeps, Virgílio confere ao Troiano uma importância que reflecte as esperanças da época. Galinsky 1996: 226 refere a influência da experiência da geração de Virgílio na literatura: "This was a generation that had lived through the turmoil of the late republic and the civil wars, and that experience profoundly shaped its outlook. It yearned for peace, stability, and a restoration of the basic Roman values. (...) that is no question that he [i. e. Virgílio] and his contemporaries had seen the fullness of human suffering, helplessness, and displacement: Aeneas' existence as a refugee and exile is one of the many responsive chords this character would strike at the time."

Assim, a obra de Virgílio reflecte os condicionalismos morais, históricos e políticos da época em que foi composta e da vivência do próprio autor. Ao contrário de Ovídio, Virgílio sofreu com os conflitos que culminaram com a subida de Octaviano ao poder e testemunhou a agitação patriótica provocada pela união de Marco António e Cleópatra, derrotados em 31 a. C. em Áccio. Se Virgílio trabalhou na Eneida durante dez anos, até à sua morte em 19 a. C., a contiguidade com este período conturbado da história de Roma condiciona a interpretação da obra. Virgílio está ainda demasiado próximo de Cleópatra, para que não seja evidente a associação desta a Dido. $O$ perigo da mulher estrangeira que seduz um herói romano, reduzindo-o praticamente a um autómato, é um tema querido da propaganda augustana contra António ${ }^{15}$. Por outro lado, a relação de Virgílio com Névio sugere a associação de Dido ao passado mais distante das guerras púnicas e do perigo que Cartago representou para Roma.

\footnotetext{
${ }^{15}$ Cf. Prop. 3.11 e Hor. Carm. 1.37.
} 
À data em que Ovídio compóe as Heróides, pelo menos as primeiras quinze epístolas ${ }^{16}$, Roma vive um período de estabilidade. Ao contrário de Virgílio, Ovídio desfrutou da pax augusta e colheu os frutos de um poder já estabelecido. A efervescência social e política que derrotou António em Áccio, representada na Eneida no escudo de Eneias (A. 8.676ss.), atenuou-se visivelmente. Por este motivo, a importância ética e política assumida pelo ancestral troiano que, fugindo com o pai e as imagens dos deuses sobre os ombros e com o filho pela mão, traz para Roma o valor da pietas não é mais a mesma. Este distanciamento permite a Ovídio a tarefa audaz de se aproximar da epopeia virgiliana, reduzindo a complexidade das interpretaçóes que a enreda e retirando as personagens do contexto épico, mas, acima de tudo, afastandoas dos condicionalismos políticos inerentes à propaganda augustana. As leis por que se regem já não são as leis inefáveis do Estado e dos deuses, mas tão-somente as regras que subjazem às relaçóes de afecto individuais. Ao julgar Eneias de acordo com este código, Ovídio condena-o e absolve Dido dos seus pecados de sedutora insidiosa e de inimigo de Roma. Por este motivo, na obra de Ovídio, Dido mostra-se mais racional do que em Virgílio e, mesmo sofrendo, analisa com lucidez os acontecimentos e a responsabilidade, a sua e a de Eneias, no desenrolar do episódio.

${ }^{16}$ A data de composição das Heroides é problemática. No entanto, Jakobson 1974: 316 aponta para uma data não anterior a $10 \mathrm{a}$. C., nem posterior a 3 a. C. 


\section{Anexo \\ Epístola escrita por Dido a Eneias}

"É assim que, quando os destinos o reclamam, derrubado nas ervas húmidas, canta junto dos vaus do Meandro o cisne branco.

Não é porque espere que tu te possas comover com a minha prece que falo (sei que a começo contra a vontade de um deus).

Mas já que a minha conduta para contigo, a reputaçāo, a castidade do meu 5

em vão eu perdi, perder palavras é coisa insignificante.

[corpo e do meu espírito Estás mesmo decidido a partir e a deixar a pobre Dido, e os mesmos ventos [levarão as velas e os juramentos.

Estás decidido, Eneias, a desamarrar as naus e a dissolver ao mesmo tempo o nosso compromisso e a procurar os reinos ítalos, que não sabes onde ficam.

Não te impressionam a nova Cartago, nem as muralhas em crescimento, nem o poder supremo entregue ao teu ceptro.

Foges do que está feito, procuras o que está por fazer. Tinhas o dever de procurar pelo mundo uma terra e encontraste outra.

Ainda que encontres a terra que procuras, quem a entregará à tua posse?

Quem cederá os seus campos a desconhecidos?

Esperam-te seguramente um novo amor e uma nova Dido e novas promessas a que novamente faltarás..

Quando fundarás uma cidade como Cartago?

Quando observarás, orgulhoso, o teu povo do alto da cidadela? 20 No momento em que todas estas coisas se concretizarem (não demorem os [deuses os teus votos)

donde virá para ti uma esposa que te ame assim?

Ardo como os archotes de cera impregnados de enxofre, como o incenso sagrado deitado sobre os altares fumegantes.

Eneias está sempre à frente dos meus olhos, quando não consigo dormir, 25 Eneias é trazido ao meu espírito pela noite e pelo sossego.

Mas ele éum mal agradecido e mantém-se indiferente perante as minhas dádivas e, se eu não fosse ignara, preferiria viver sem ele.

E no entanto não odeio Eneias, apesar de as intençóes dele náo serem

[idóneas, 
mas queixo-me da sua falta de boa fé e, depois de me ter queixado, 30 [ainda o amo mais.

Poupa a tua nora, Vénus, e abraça o teu duro irmão, irmão Amor, para que ele milite nas tuas guerras.

Ou que ele, já que fui eu quem tomou a iniciativa neste amor

[(e não me envergonho)

que ele se permita ser o objecto das minhas penas.

Engano-me e revolve-se à minha frente, no meu engano, esta imagem:

ele é diferente do espírito de sua mãe.

A ti geraram-te pedras, montes e carvalhos nascidos no alto dos rochedos, a ti geraram-te as feras selvagens ou o mar, tal como o vês agora a ser agitado até pelos ventos, por onde te preparas para partir, mesmo com as ondas adversas?

Para onde foges? A tempestade opóe-se. Que a tempestade me ajude!

Observa como o vento de leste agita as águas revoltosas.

Deixa que eu deva às tempestades o que preferiria dever-te a ti.

Tanto o vento como o mar sáo mais justos do que a tua alma.

Eu não mereço (estarei a avaliar-te de forma injusta?)

que tu morras enquanto foges de mim através da vastidão do mar.

Nutres um ódio precioso e que custa caro,

se, contanto que estejas livre de mim, não te importas de morrer.

Já os ventos se acalmarão e, niveladas as vagas,

Tritão correrá pelo mar nos seus cavalos de cor azul.

Oxalá também tu pudesses mudar com o vento

e, a menos que sejas mais duro do que os carvalhos, haverás de mudar.

Porque é que, como se não soubesses o que podem fazer as águas

[em fúria,

confias no mar que tantas vezes e com táo maus resultados conheceste?

Ainda que levantes amarras com o mar a aconselhar-te a viajar,

a vastidão do ponto encerra muito sofrimento.

E não é bom para aqueles que enfrentam o mar terem terem faltado às

[promessas feitas.

Aquele lugar exige um castigo para a perfídia,

especialmente quando se lesou o amor,

porque se diz que a mãe dos Amores nasceu nua nas águas de Citera.

Depois de me ter perdido, temo perder ou fazer mal a quem me fez mal.

Que o meu inimigo, náufrago, não beba a água do mar.

Vive, peço-te! É que deste modo perder-te-ei melhor do que pela morte.

Antes se diga que tu foste a causa da minha.

Vá, imagina (afaste-se o mau agoiro!)

que és apanhado num turbilhão, o que é que surgirá na tua mente? 
Logo te lembrarão os perjúrios da tua boca mentirosa e Dido obrigada a morrer pela fraude cometida por um Frígio.

Entâo aparecerá perante os teus olhos a imagem triste, ensanguentada e de cabelos desgrenhados da esposa enganada.

De que valerá dizeres então "É o que eu mereci, perdoai-me"

e julgares que foram enviados contra ti os raios que então caírão?

Dá um pouco de tempo à crueldade, à do mar e à tua.

A grande recompensa da demora há-de ser uma viagem segura.

Ainda que não te preocupes com estes problemas, poupe-se o pequeno Julo!

Para ti é suficiente ter a honra de ter causado a minha morte.

Mas que mereceram o pequeno Ascânio ou os deuses Penates?

Haverá o mar de engolir os deuses que foram salvos das chamas?

Mas não trazes contigo nem, como te pavoneias para mim, pérfido,

pesaram nos teus ombros as imagens sagradas ou o teu pai.

Era tudo mentira. E a tua boca não começou por mim a enganar, eu é que sou a primeira a queixar-me:

se se perguntar onde está a mãe do formoso Julo...

morreu sozinha, abandonada por um marido insensível!

Tais coisas me havias contado e a mim comoveram-me. Destrói-me a mim

porque mereço: o meu castigo será menor do que a culpa.

E eu não tenho dúvidas de que os teus deuses te estão já a castigar: é este o sétimo inverno que te faz vaguear por mar e por terra.

Rejeitado pelas ondas acolhi-te num abrigo seguro

e, mal ouvido com clareza o teu nome, dei-te um reino.

Oxalá me tivesse contentado com tais ofertas

e a minha reputação não teria acabado por causa da nossa união.

$\mathrm{O}$ dia que me prejudicou foi aquele em que uma nuvem escura e imprevista nos reuniu debaixo da inclinação de uma caverna.

Tinha ouvido uma voz, julguei que eram as ninfas a uivar, mas eram as Euménides a indicarem o meu destino.

Aplicai um castigo, castidade ultrajada, leis profanadas do leito partilhado, reputação que não mantive até à minha morte,

e vós, almas dos meus familiares mortos, e a alma e a cinza de Siqueu, 97b para junto das quais, pobre de mim, vou cheia de vergonha.

Eu consagrei um templo de mármore à memória de Siqueu com a parte da frente coberta de folhas e velos de cor branca.

Foi daqui que ouvi uma voz conhecida chamar-me quatro vezes.

Foi ele próprio quem disse baixinho: "Elissa, vem!".

Não há demora alguma: venho, venho para ti como a esposa que te é devida.

Todavia, venho lentamente por causa da vergonha causada pelo crime que cometi.

Sê indulgente para com a minha culpa: foi um mestre 
hábil quem me enganou.

A sua actuação retira a má vontade à minha culpa.

A deusa que é sua mãe e o seu velho pai, fardo de um filho dedicado, deram-me a esperança de um marido que, de acordo com as normas,

[haveria de ficar a meu lado.

Se eu tive de errar, o meu erro tem causas virtuosas:

se se considerar também a boa-fé, em nenhum aspecto deveria ser um $\quad 110$

[crime repugnante.

Dura até ao fim, até aos últimos momentos da minha vida, e continua a perseguir-me o destino que já antes me acompanhava.

O meu marido morreu sacrificado junto dos altares domésticos e é o meu irmão quem tem o prémio de tamanho crime. Vou-me embora, exilada, e deixo para trás as cinzas do meu marido

[e a minha pátria.

Dirijo-me para caminhos perigosos, com o inimigo no meu encalço.

Aporto a esta costa, depois de escapar ao meu irmáo e ao mar,

e compro, pérfido, o litoral que te dei.

Fundei uma cidade e estabeleci muralhas que se estendem a perder de vista

e que provocam a inveja dos povos vizinhos.

Preparam-se guerras. Com guerras sou atacada por ser estrangeira e mulher, e, sem experiência, preparo a custo as portas da minha cidade e as armas. Agradei a mil pretendentes, que se juntaram contra mim, queixando-se de que preferi um indivíduo qualquer em vez das suas propostas de

[casamento.

Porque hesitas em me entregar, acorrentada, ao getulo Jarbas?

Eu teria oferecido os meus braços ao teu crime.

Há ainda o meu irmão que procura manchar com o meu sangue as suas mãos ímpias, já manchadas com o sangue do meu marido. Deixa os deuses e as imagens sacras que profanas só de lhes tocar. A tua ímpia mão direita não reverencia os deuses como convém.

Se eras tu quem tinha a intençáo de reverenciar os deuses que salvaste

[do incêndio,

são eles quem se arrepende de terem sido salvos das chamas.

Talvez abandones até, criminoso, Dido grávida

e parte de ti se esconda, fechada, no meu corpo.

A triste criança juntar-se-á ao destino da mãe

e tu serás o responsável pela sua morte, mesmo antes de ter nascido.

Com a sua mãe morrerá o irmão de Julo,

e um mesmo castigo levar-nos-á a ambos, unidos um ao outro.

"Mas é um deus que me ordena que vá embora." Oxalá te tivesse 
e a terra púnica não tivesse sido pisada pelos Teucros.

É certamente com a protecçâo deste deus que és atormentado por

[ventos adversos

e que perdes tanto tempo no mar agitado?

Dificilmente com tanto sacrifício valeria a pena regressares a Pérgamo, ainda que, estando Heitor ainda vivo, tudo fosse como era antes. Não é o Simoente da tua pátria que procuras, mas as águas do Tibre: mesmo que chegues onde queres serás certamente um estrangeiro. E tendo em conta que a terra que procuras se esconde de ti e,

[dissimulada, escapa às tuas naus, talvez tenhas a sorte de a encontrar na tua velhice.

Deixa-te de rodeios e recebe antes estes povos como dote e as riquezas de Pigmalião que trouxe comigo.

É melhor mudares Ilion para a cidade Tíria e receberes o poder e o ceptro sagrado de rei. Se o teu carácter deseja guerra, se Julo procura de onde lhe venham triunfos conseguidos pela sua forma de combater, eu oferecer-lhe-ei um inimigo para vencer, para que não lhe falte nada. Aqui há ocasião para as leis da paz e para as armas.

Tu, pelo menos - pela tua mãe e pelas armas fraternas, as setas, pelos deuses, companheiros de fuga, imagens sagradas dardânias, (assim vençam todos aqueles que da tua raça o fero Marte transporta e seja este o limite da tua desgraça. Que Ascânio passe os seus anos de forma feliz e os ossos do velho Anquises repousem em paz!) poupa, peço-te, a minha casa, que se entrega à tua posse! Que crime dizes que cometi a não ser o de ter amado? Eu não sou Ftia nem oriunda da grande Micenas, nem se posicionaram contra ti o meu pai ou o meu marido.

Se te envergonhas de que eu seja tua esposa, não se diga que casei contigo [mas que sou tua anfitriá.

Desde que seja tua, Dido suportará ser o que quer que seja.

Eu conheço os mares que ferem o litoral Africano.

Possibilitam e impedem a viagem em dias fixos:

quando a brisa permitir, abrirás as velas ao vento; agora as algas finas retêm o teu navio encalhado.

Deixa que eu decida qual a ocasião certa. Partirás com maior segurança e, se quiseres, eu própria te impedirei de ficar.

Até os companheiros te pedem descanso, e a armada destroçada, ainda não reparada na toltalidade, requer ainda uma pequena demora. Pelos bem que te fiz e por mais alguma coisa que te possa ainda vir a oferecer, 
não é pela esperança do casamento que te peço um pouco mais de tempo: enquanto o mar e o amor suavizam, enquanto com o passar do tempo

[e pela força do hábito,

talvez aprenda a suportar a tristeza.

Se não, é minha intenção pôr um termo à minha vida.

Náo podes ser cruel para mim durante muito mais tempo.

Oxalá visses a minha imagem enquanto te estou a escrever:

escrevo e no meu colo está a espada Troiana,

Através das minhas faces as lágrimas escorrem para a espada

que em breve, em vez de lágrimas, será manchada pelo sangue.

Que bem que os teus presentes se adaptam ao meu destino!

Constróis o meu sepulcro com uma despesa muito pequena.

Não é esta a primeira vez que o meu coração é ferido pela espada:

neste lugar existe já a ferida do violento Amor.

Ana minha irmã, minha irmã Ana, infelizmente cúmplice da minha culpa,

darás em breve os últimos dons às minhas cinzas.

E quando eu tiver sido consumida pelas chamas da pira não se afixe a inscrição: "Elissa de Siqueu".

No mármore do túmulo estará apenas este pequeno epigrama:

"Eneias ofereceu a causa da morte e a espada.

A própria Dido caiu usando a sua mão" 
Capítulo III

ReElaboraçÃo ÉPICA:

Virgílio vs. Ovídio nos Punicorum libri de Sílio Itálico 
A Segunda Guerra Púnica, que ocorreu entre 218 e 201 a. C. e opôs uma vez mais Romanos e Cartagineses, é o tema dos Punicorum libri de Sílio Itálico. Nesta obra, o autor explora não só o confronto bélico, mas também a diferença de valores entre os dois povos, condenados pelo destino (e pelos interesses económicos no Mediterrâneo) a serem inimigos.

Neste contexto, Dido retoma o papel que Virgílio lhe atribuíra, ao fazê-la pronunciar a célebre maldiçấo sobre os descendentes dos Troianos e dos Cartagineses:

Tum uos, o Tyrii, stirpem et genus omne futurum exercete odiis, cinerique haec mittite nostro munera. Nullus amor populis, nec foedera sunto. Exoriare aliquis nostris ex ossibus ultor, qui face Dardanios ferroque sequare colonos, nunc, olim, quocumque dabunt se tempore uires. Litora litoribus contraria, fluctibus undas imprecor, arma armis; pugnent ipsique nepotesque. (A. 4.622-29)

"E vós, ó Tírios, persegui com o vosso ódio a raça e toda a [descendência que dela advirá; enviai esta dádiva às minhas cinzas. Não haja amizade alguma ou alianças entre os dois povos. Que surja dos meus ossos um vingador, quem quer que seja, que com archotes e espadas persiga os colonos dardânios, agora, no futuro e sempre que as forças lho permitirem. Praias contra praias, vagas contra ondas, - é este o meu desejo - armas contra armas. Lutem eles e os seus [descendentes.”

Em Sílio Itálico, Dido é a inspiradora da hostilidade eterna entre os dois povos e, no elenco das causas desta hostilidade, a história da sua fuga ocupa o primeiro lugar:

Pygmalioneis quondam per caerula terris pollutum fugiens fraterno crimine regnum fatali Dido Libyes appellitur orae. 
tum pretio mercata locos noua moenia ponit, cingere qua secto permissum litora tauro. (1.20-5)

"Tendo vindo, em tempos, dos domínios de Pigmalião, através dos mares,fugindo do reino manchado pelo crime cometido pelo irmão, Dido desembarca na costa que the foi indicada pelo destino.

Então, tendo adquirido aqueles locais, construiu novas muralhas, na praia que conseguiu abranger com uma pele de boi cortada em tiras."

Desde a sua fundação, Cartago passou a ser a cidade predilecta de Juno que, receando o poder crescente de Roma, contra ela instigou o espírito aguerrido dos Cartagineses (1.26-33). Amílcar, descendente de um dos companheiros de viagem de Dido, viveu sob o signo da inimizade entre os dois povos e, desde a infância de Aníbal, incutiu no filho um ódio profundo a Roma (1.77-80).

É no templo consagrado aos manes da rainha que Amílcar ouve o filho, o pequeno Aníbal, jurar que nenhuma empresa merecerá mais empenho da sua parte do que a guerra contra os Romanos:

Romanos terra atque undis, ubi competet aetas, ferro ignique sequar Rhoeteaque fata reuoluam. non superi mihi, non Martem cohibentia pacta, non celsae obstiterint Alpes Tarpeiaque saxa. hanc mentem iuro nostri per numina Martis, per manes, regina, tuos. (1.114-19)

"Quando a idade for conveniente, pela terra e pelos mares, perseguirei com a espada e o fogo os Romanos e farei retroceder os [fados do Reteu ${ }^{1}$.

Nem os deuses nem os pactos que proibem a guerra nem os cumes dos Alpes ou a rocha Tarpeia serão obstáculo para

Juro pela minha saúde e pelo poder do nosso Marte, $[\mathrm{mim}$. e pelos teus Manes, rainha.'

Reconhecem-se no juramento alguns ecos da maldição proferida por Dido. Como esta previra, o vingador da sua morte perseguirá os descendentes de Eneias com o fogo e com a espada, elementos que caracterizaram a paixáo (mais precisamente, o fogo e o ferimento metafórico do amor) e o suicídio da rainha.

${ }^{1} \mathrm{O}$ cabo Reteu era um promontório na Tróade, logo, os destinos do Reteu seráo os dos Troianos, enquanto antepassados do povo Romano. 
Também a cerimónia celebrada no templo estabelece uma ponte entre o passado e o presente, entre a fundadora de Cartago e aquele que será o vingador por ela reclamado. Como Dido, também Aníbal será o instrumento da cólera de Juno contra os descendentes de Eneias. A cerimónia é um teste à coragem do filho de Amílcar (1.99-103): perante as imagens dos antepassados fenícios, a sacerdotisa de origem massila ${ }^{2}$ invoca os deuses dos Infernos (1.93-4), a terra ruge e emite silvos arrepiantes (1.95-6), o fogo acende-se espontaneamente nos altares (1.96), os manes invocados aparecem (1.97-8) e da estátua de Dido brota o suor (1.98). A energia negativa que domina este momento parece transmitir a Aníbal a força nefasta da maldição proferida por Dido na Eneida.

Contrastando com o ambiente sinistro do templo, a ternura entre pai e filho concede aos votos de Aníbal o carácter de uma herança. A inimizade entre os dois povos é mais do que um capricho: é um património familiar e, mais do que isso, uma tradição nacional. Também Aníbal encarregará a mãe do seu filho de transmitir à criança este legado, como ele próprio o recebeu do pai, naquele dia no templo:

Cumque datur fari, duc per cunabula nostra; tangat Elissaeas palmis puerilibus aras et cineri iuret patrio Laurentia bella. (3.81-3)

"E quando for capaz de falar, leva-o aos lugares da minha infância; que toque com as suas mãos pueris o altar de Elissa e prometa às cinzas do pai a guerra contra Laurento."

É também no templo consagrado a Dido que a criança deve jurar fazer a guerra contra Roma, continuando a missão do seu pai. É como se o santuário fosse um lugar mágico em que a rainha transmite o poder da sua cólera. Os ingredientes mágicos e sinistros com que o autor caracteriza a cerimónia do templo transformam o instinto guerreiro de Aníbal numa força sobrenatural de carácter destrutivo. A ligaçáo entre o mundo dos mortos e o dos vivos que a cerimónia estabelece transmite ao jovem cartaginês o ódio de Dido, que atravessa o tempo, mas é, simultaneamente, de acordo

${ }^{2} \mathrm{Na}$ Eneida (A. 4.483ss.), para ludibriar Ana, Dido afirma que foi uma sacerdotisa da mesma origem quem lhe recomendou que fizesse um sacrifício para garantir o regresso de Eneias ou para se curar do amor que por ele nutria. 
com Hardie 1993: 64-5, uma ponte entre a épica virgiliana e a obra de Sílio Itálico, pelo encadeamento que constitui relativamente aos acontecimentos narrados na Eneida.

A estátua de Elissa que se encontra no templo imortaliza a relaçáo de Dido com Siqueu, tornada eterna na reunião realizada pela morte. Imortalizado o casamento legítimo da rainha, como nos Infernos (A. 6.473-4), é ao lado de Siqueu que Dido completa o ciclo da sua vida. Mas, aos pés do casal, vê-se a espada oferecida por Eneias, como uma acusação perpétua, como um sinal de hostilidade, da hostilidade contra Eneias e contra os seus descendentes:

Ipsa sedet tandem aeternum coniuncta Sychaeo; ante pedes ensis Phrygius iacet. (1.90-1)

"Ela está sentada, finalmente unida a Siqueu para sempre. Jaz à frente dos seus pés a espada frígia."

$\mathrm{Na}$ união final com Siqueu, Dido regressa ao seu passado, recupera o primeiro casamento. Todavia, nem a morte apaga o desejo de vingança, que continua a inspirar os Cartagineses. É deste modo que Sílio Itálico explora a relação de causalidade entre a cólera de Dido e as guerras púnicas, insinuada em Virgílio e, aparentemente, já antes, na obra de Névio.

A dualidade inerente à caracterização de Romanos e Cartagineses retoma a oposição que na Eneida se estabelece entre Eneias e Dido. O herói troiano e os seus descendentes são a personificação da pietas e do equilíbrio, do respeito pelos deuses e da rectidão. Dido, Aníbal e os Cartagineses, pelo contrário, seguem valores duvidosos. Sáo infiéis às alianças contraídas, confirmando a reputaçáo da fides punica ${ }^{3}$. Sucumbem perante o furor e os excessos: Dido perante o excesso de amor, Aníbal perante o excesso do impulso guerreiro que o caracteriza. Povos tão diferentes só podiam ser inimigos viscerais, especialmente quando o encontro infeliz de Dido e Eneias lançou as sementes imorredouras do ódio que acompanhou a convivência entre os descendentes de ambos.

${ }^{3}$ Reputação que Hanão, cartaginês hostil à família dos Barcas, pretende afastar de Cartago, exortando os seus concidadãos a deter Aníbal e a negociar a paz com os Romanos, aproveitando os sucessos por aquele alcançados (11.596-7) fama fugetur ab urbe / perfidiae, Phoenissa, tua. "Que a reputação de ser pérfida seja afastada, Fenícia, da tua cidade.”. 
A desconfiança que os Romanos exprimem relativamente aos Cartagineses espelha-se na estranheza sentida perante uma cidade fundada por uma mulher. Durante o cerco de Sagunto, que denuncia as intençóes hostis de Aníbal contra Roma e os seus aliados, Dauno, cidadão saguntino conhecido pela sua eloquência, diz ao líder do exército cartaginês:

Quaenam te, Poene, paternae

huc adigunt Furiae? non haec Sidonia tecta

feminea fabricata manu pretioue parata, exulibusue datum dimensis litus harenis.

fundamenta deum Romanaque foedera cernis. (1.443-7)

"Que Fúrias paternas, Púnico, te trazem aqui? Estas não são as moradas sidónias, construídas pela mão de uma mulher e adquiridas a um preço marcado, nem a praia cedida a forasteiros, depois de ter sido medido

O que vês são alicerces divinos e aliados a Roma."

[o areal.

A diferença entre Cartago e Sagunto é evidente. A primeira náo se limita a ser obra de simples mortais. Pior do que isso, foi fundada por uma mulher, que, recorrendo ao dolo, teve de comprar um pedaço de terra para aí construir uma cidade. Sagunto, pelo contrário, como aliada de Roma, desfruta de um estatuto quase divino. Em várias ocasióes, Cartago é designada como a cidade de Dido (2.391; 6.312-13; 7.488-9; 11.596-7). Por este motivo, o destino da sua fundadora condiciona o destino da própria cidade, porque uma e outra estão ligadas ab initio. Cartago não existiria se Dido náo tivesse fugido do crime de Pigmalião e da ignomínia que este lançara sobre a Fenícia. Cartago tem, assim, origens pouco dignas.

A acrescentar a estes factores pouco abonatórios, o povo de Dido é também o povo que imola crianças em honra dos deuses:

Mos fuit in populis, quos condidit aduena Dido, poscere caede deos ueniam ac flagrantibus aris, infandum dictu! paruos imponere natos. (4.765-7)

"Era costume dos povos que a estrangeira Dido fundou pedir o perdão dos deuses com a morte e pôr sobre os altares em chamas - facto horrível de referir! - crianças de tenra idade.” 
A prática de sacrifícios humanos, especialmente de crianças, torna os Cartagineses um povo de costumes abomináveis aos olhos dos Romanos 4 . Aníbal, no entanto, quando recebe a visita de embaixadores de Cartago que lhe pedem autorização para sacrificar o seu único filho, recusa o seu consentimento, alegando que a criança tem de dar continuidade ao seu legado de ódio contra Roma (A. 4.814ss.). Em troca deste sacrifício, promete imolar vítimas romanas. A decisão de poupar o filho parece, por esta razáo, menos inspirada no afecto paterno do que na necessidade de manter viva a hostilidade contra Romas.

A presença de Dido ultrapassa, todavia, os limites da causalidade bélica. Sílio Itálico não desprezou o delinear da paixão que condicionou a vida da rainha de Cartago. Também ele sucumbiu ao lado mais afável de Dido e apresentou de forma notável e pormenorizada os principais momentos do encontro desta com Eneias.

No escudo que os Galaicos fizeram para Aníbal estavam representados alguns dos acontecimentos mais importantes da história de Cartago. As primeiras cenas descritas são a reprodução de momentos da vida da rainha, desde a fundação de Cartago ao suicídio na pira. O escudo resume, assim, os primeiros livros da Eneida. A evocação do seu papel como fundadora da cidade opera-se através da descrição da azáfama dos trabalhos de construção (2.406-9) e do presságio favorável que constituiu a cabeça de cavalo encontrada nas primeiras escavaçóes (2.410-11). De seguida, aparece no escudo Eneias:

Has inter species orbatum classe suisque

Aenean pulsum pelago dextraque precantem

cernere erat. (2.412-14)

"Entre estas imagens era possível distinguir, privado da armada e dos seus, Eneias, repelido pelo mar e com a mão direita em posição de súplica."

O herói encontra-se em situação precária, no momento em

${ }^{4}$ Note-se a expressividade do verso 767 , em que apenas o quinto pé é um dáctilo, característica que confere ao verso um tom de manifesta indignação.

${ }^{5}$ Ainda que na Eneida não se refira o costume tírio de sacrificar crianças, podemos vislumbrar indícios desta prática na cólera manifestada por Dido, quando se vê na iminência de ser abandonada por Eneias e exprime o arrependimento de náo ter dilacerado o corpo do pequeno Ascânio $(A$. 4.601-2). 
que, após ter desembarcado na Líbia depois da tempestade desencadeada por Juno, julga perdida grande parte da sua armada e dos seus homens. Revela a aflição do Troiano o facto de ser representado em atitude de suplicante. Mas, logo a seguir, como um antídoto, surge a imagem da rainha, que o esperava:

Fronte hunc auide regina serena

infelix ac iam uultu spectabat amico. (2.414-15)

"A este contemplava-o de rosto sereno e com avidez a rainha, infeliz, e já de aparência afectuosa."

A inexorabilidade do destino de Dido adivinha-se já no adjectivo infelix. Ironicamente, é a forma pacífica com que Dido acolhe os Troianos que sobressai da descrição que, no entanto, deixa transparecer a premência da paixão da rainha. Segue-se na ekphrasis o encontro de ambos na caverna onde se refugiaram da intempérie que os surpreendeu durante a caçada:

Hinc et speluncam furtiuaque foedera amantum (...)

Callaicae fecere manus (...) (2.416-7)

"Deste lado, representaram também os Galaicos

a gruta e o compromisso secreto entre os amantes."

A classificação da relação dos dois como furtiua foedera (2.417) retoma o comentário da Eneida acerca da forma como Dido interpreta o que aconteceu na gruta $(A .4 .171-2)$. A seguir ao encontro, vê-se no escudo a separação. A armada troiana faz-se ao mar, enquanto Dido fica na praia:

Nec procul Aeneadum uacuo iam litore classis aequora nequicquam reuocante petebat Elissa. (2.420-1)

"E não longe dali a armada dos Enéadas dirigia-se para o mar, deixando para trás a praia deserta e Elissa que em vão lhes pedia [que voltassem."

O afastamento dos dois é definitivo: Eneias está já a bordo do seu barco, Dido está sozinha na praia vazia, chamando-o em vão. Consumada a separação, é a morte da rainha que se apresenta de seguida: 
Ipsa, pyram super ingentem stans, saucia Dido mandabat Tyriis ultricia bella futuris. (2.422-3)

"De pé sobre a pira ingente, a própria Dido, ferida, confiava aos futuros Tírios as guerras vingadoras."

Sobre a pira, Dido prevê a inimizade entre os povos, que não será mais do que a vingança da ofensa de Eneias à rainha. Este, contemplando ao longe o fogo da pira, dirigia-se já para o Lácio (2.424-5). É com a visualização de Eneias no mar que termina a representação do encontro deste com Dido. É o confronto entre os dois povos que domina as imagens que se descrevem a seguir: o juramento de Aníbal, Amílcar na Sicília, etc.

A economia da ekphrasis condiciona o carácter conciso da descrição da história de Dido, reduzida aos momentos mais importantes: o encontro de ambos, a união na gruta, a separação e a morte da rainha. Por este motivo, as implicaçóes de ordem moral são omitidas. Porém, quando, no livro 8, Juno convoca Ana, a irmã de Dido, venerada pelos Romanos como Ana Perena, para dar coragem a Aníbal (8.29ss.), o episódio é novamente evocado e de forma mais pormenorizada. A escolha de Ana para esta tarefa baseia-se na sua origem, comum à de Aníbal. A resposta da irmã de Dido a Juno é elucidativa da afinidade entre ambos:

"haud," inquit, "tua nobis praecepta morari.

sit fas, sit tantum, quaeso, retinere fauorem

antiquae patriae mandataque magna sororis, quamquam inter Latios Annae stet numen honores." (8.40-3)

"Não me é lícito - diz - adiar o cumprimento das tuas ordens. Seja-me apenas permitido, peço-te, manter a afeição da minha antiga pátria e os preceitos importantes da minha irmã, ainda que o poder de Ana continue a ser respeitado entre os Latinos."

O único desejo de Ana é o de respeitar os pedidos da irmá, mesmo que o povo romano a venere. Embora tendo terminado a sua vida no Lácio, Ana é ainda uma cartaginesa, é ainda a irmá de Dido. Por esta razão, também ela dará continuidade à inimizade entre os dois povos que, efectivamente, é um legado deixado por Dido a todos os seus concidadãos. 
A estranheza suscitada pelo facto de os Romanos prestarem culto a uma divindade de origem cartaginesa (8.44-7) justifica o excurso que se segue. Tomando como modelo a história de Ana Perena nos Fastos de Ovídio (3.543ss.), Sílio Itálico narra a história de Ana desde a morte da irmá, retomando, assim, a narrativa dos acontecimentos ocorridos em Cartago, no ponto em que termina o livro 4 da Eneida:

Iliaco postquam deserta est hospite Dido, et spes abruptae, mediam in penetralibus atram

festinat furibunda pyram: tum corripit ensem

certa necis, profugi donum exitiale mariti.

despectus taedae regnis se imponit Iarbas,

et tepido fugit Anna rogo (...) (8.50-5)

"Depois de ter sido abandonada pelo hóspede de Ílion e de ter perdido a esperança, Dido, em fúria, avança apressadamente para a pira funesta, erguida no meio da casa; entâo, decidida

lança mão da espada, presente fatal do marido fugitivo.

[a morrer,

Jarbas, com quem Dido recusara casar-se, estabelece-se no reino e Ana foge quando a pira estava ainda tépida."

Recolhendo os elementos mais importantes que causaram a morte de Dido, nomeadamente o abandono e a fuga de Eneias e o consequente desequilíbrio emocional da rainha, bem como o fogo da pira e o uso dado por Dido à espada que lhe tinha sido oferecida por Eneias, o resumo dos acontecimentos mostra, na forma como entende a ligação de Dido e Eneias, um cunho ovidiano, já que designa o Troiano como maritus da rainha. Do mesmo modo, a caracterização de Eneias como fugitivo, ainda que presente na Eneida $(A .4 .281 ; 4.314 ; 4.328$, etc.), é explorada com maior ênfase por Ovídio (Ep. 7.13, 41, 46; Met. 14.82), que transforma o Troiano num indivíduo que foge de Dido utilizando o destino como pretexto.

Depois de ter fugido de Cartago e após ter experimentado algumas peripécias, Ana desembarca na Itália, onde encontra Eneias. Ainda que no início se mostre desconfiada e assustada ${ }^{6}$, é acolhida de forma amigável pelo Troiano que a recebe no seu palácio. Aí, Eneias pede a Ana que lhe conte como morreu a irmã:

${ }^{6}$ Também Ovídio (Fast. 3.609-10) mostra uma Ana assustada quando reconhece Eneias. 
tum discere maesta

exposcit cura letum infelicis Elissae. (8.77-8)

"Então, com grande pena, pede que lhe conte a morte da infeliz Dido."

Ao contrário da versão dos Fastos de Ovídio, na obra de Sílio Itálico, Eneias omite qualquer referência ao encontro com Dido nos Infernos, tornando, assim, necessária a analepse. Esta omissão permite incluir alguns elementos de cunho virgiliano num episódio que se baseia na obra referida de Ovídio. Justifica, deste modo, o relato de Ana, que começa com a afirmação da importância que o herói tinha na vida de Dido:

Nate dea, solus regni lucisque fuisti germanae tu causa meae. (8.81-2)

"Filho de uma deusa, tu foste a única razão para que a minha irmã reinasse e vivesse.”

Sem razão para viver, Dido terá caído em desespero. $\mathrm{O}$ uso de adjectivos como turbida 'agitada' (8.88), amens 'demente' (8.91) e furibunda 'em fúria' (8.96) mostra o estado psicológico alterado da rainha. Na praia, desesperada, ora se senta ora se levanta (8.84-5), chama Eneias e pede que a leve consigo (8.86-8). Depois corre para o quarto, mas pára repentinamente, arrepiada e com receio de tocar no leito (8.88-90). Abraça a imagem de Julo, depois vira-se de repente para a imagem do rosto de Eneias queixando-se para ela e dela esperando uma resposta (8.91-4). Assim, confundindo ilusão e realidade, procura novamente Eneias no porto, com a esperança de que o vento tenha feito regressar a armada. Mas a prova máxima da loucura de Dido é, de acordo com as palavras de Ana, o facto de ter recorrido à magia:

"ad magicas etiam fallax atque improba gentis

Massylae leuitas descendere compulit artes.

heu sacri uatum errores! dum numina noctis

eliciunt spondentque nouis medicamina curis

(quod uidi decepta nefas!') congessit in atram

cuncta tui monumenta pyram et non prospera dona." (8.98-103) 
"A enganadora e perversa falta de carácter da gente Massília levou-a a chegar ao ponto de recorrer à magia.

Ó erros abomináveis dos profetas! Enquanto as divindades da noite a seduzem e lhe prometem remédios para novas penas (a que crime eu, iludida, assisti!) reuniu na pira funesta todas as lembranças de ti e os presentes que lhe não foram propícios."

Sob a influência nefasta das artes mágicas, Dido planeou metodicamente a sua morte, sem que Ana se apercebesse da verdadeira finalidade da cerimónia que ajudou a preparar.

Quando refere a presença das lembranças e dos presentes de Eneias na pira, este irrompe em juras e lamentos:

Tunc sic Aeneas dulci repetitus amore:

"tellurem hanc iuro, uota inter nostra frequenter auditam uobis; iuro caput, Anna, tibique germanaeque tuae dilectum mitis Iuli, respiciens aegerque animi tum regna reliqui uestra, nec abscessem thalamo, ni magna minatus meque sua ratibus dextra imposuisset et alto egisset rapidis classem Cyllenius Euris,» (8.104-11)

"Então Eneias, relembrando-se do doce amor diz: 'juro por esta terra que tantas vezes nas minhas preces me ouvistes nomear; juro, Ana, pela vida do doce Julo, querido para ti e para a tua irmá, foi olhando para trás e de ânimo aflito que naquela altura deixei o vosso reino, e não teria abandonado o tálamo, se não tivesse [sido muito ameaçado e se o Cilénio ${ }^{7}$ não me tivesse colocado com a sua mão direita e não tivesse guiado a frota no mar alto com a ajuda dos [no barco [Euros velozes'."

A reacção de Eneias é condicionada pelo amor que nele se renova (8.104), demonstrando, deste modo, de forma bastante clara, os sentimentos do Troiano em relação à rainha ${ }^{8}$ Se, na Eneida, Virgílio caracteriza de forma mais ou menos dúbia a interpretação

${ }^{7}$ Eneias refere-se ao deus Mercúrio, nascido no monte Cilene.

${ }^{8}$ Em Ovídio (Fast. 3.526), quando vê Ana, Eneias fica comovido quando se lembra de Dido, mas náo faz qualquer referência aos sentimentos que por ela nutre ou nutriu. 
que o próprio Eneias tem daquilo que sente relativamente à rainha, na obra de Ovídio é a perspectiva de Dido, que se apresenta como vítima de um homem insensível, que se impóe. Os Punicorum libri, pelo contrário, mostram-nos um herói que assume sem ambiguidades o seu amor por Dido. A justificação de Eneias para o abandono é, de facto, surpreendente. O Troiano náo alega apenas ter saído de Cartago contra a sua vontade ${ }^{9}$, mas afirma ter sido colocado na nau pela mão do próprio Mercúrio que levou a armada para o alto mar. Eneias defende-se, assim, não com a importância da missão de fundar Roma, superior à sua vontade própria, mas com o facto de ter sido, literalmente, um joguete nas mãos dos deuses. Não o tivesse Mercúrio colocado na nau e Eneias não teria deixado para trás o casamento. Deste modo, ao contrário das versóes anteriores, em que os deuses relembram ao Troiano a importância da sua missáo ${ }^{10}$, é o próprio Eneias quem reconhece, de forma inequívoca, a relação entre ambos como um casamento, já que a classifica como um thalamus (8.109).

Continuando o relato dos acontecimentos, Ana explica como, convencida de que a finalidade da cerimónia era curar o amor de Dido, se atarefava com os preparativos. Chegou mesmo a sonhar com Siqueu reclamando Dido em voz alta por três vezes, sonho que repete a alucinação de Dido na Eneida (A. 4.457-61). Afastando o receio, Ana continua a preparar o sacrifício, enquanto Dido regressa à praia, onde beija a areia que Eneias pisara e daí avança resoluta e rapidamente para a pira, construída num local de onde podia ver-se o mar e a cidade de Cartago. Os presentes de Eneias fazem, naquele momento, Dido recordar-se do passado, quando o Troiano lhe contava a destruição de Tróia e as peripécias da viagem até chegar à Líbia. Observa, então, novamente, o porto e diz:

"di longae noctis, quorum iam numina nobis mors instans maiora facit, precor', inquit, 'adeste et placidi uictos ardore admittite manes. Aeneae coniux, Veneris nurus, ulta maritum, uidi constructas nostrae Carthaginis arces. nunc ad uos magni descendet corporis umbra. me quoque fors dulci quondam uir notus amore exspectat, curas cupiens aequare priores." (8.140-7)

${ }^{9}$ Como em A. 4.361 e 6.460 .

${ }^{10}$ Nos Fastos 3.530, Eneias diz a Ana que os deuses censuraram a sua demora em Cartago. 
"Deuses da longa noite, cujo poder

a morte iminente torna maior para mim, peço-vos - diz -

[estai presentes e, benignos, admiti a minha alma vencida pelo ardor da paixão. De Eneias a esposa, de Vénus a nora, vinguei o meu marido, vi construída a cidadela da minha Cartago.

Agora, desce para junto de vós o fantasma de uma pessoa de [sentimentos nobres.

Talvez me espere também o marido que outrora conheci com

[doce amor, e deseje consolar as minhas penas anteriores."

$\mathrm{O}$ aspecto sombrio da morte da rainha entrevê-se na caracterização dos deuses que invoca ${ }^{11}$, deuses a quem entrega a sua alma, vencida pelo ardor, pelo fogo da paixão que é a causa do suicídio da rainha. Das suas últimas palavras, transparece a preocupação em manifestar o entendimento que tem da ligação com Eneias, enfatizada pela afirmaçáo do parentesco que a liga a Vénus $(8.143)^{12}$. Dido declara sem ambivalências que se considera nora legítima da mãe de Eneias. Assim, se ambos entendem a relação que os une como um casamento, a problemática de carácter moral é irrelevante. Se Dido póe um termo à sua vida por se considerar abandonada por Eneias, a verdade é que tudo não passou de um mal-entendido, já que o Troiano foi levado pelos deuses que, deste modo, são os únicos responsáveis pela tragédia que se abateu sobre a rainha. No encontro entre Dido e Eneias, estes náo passam, assim, de marionetas nas mãos das divindades, que, ao contrário das versóes anteriores, não deixam espaço para o livre arbítrio das personagens. A cólera da rainha de Cartago e dos seus descendentes contra Eneias e contra os Troianos baseiase, assim, num erro de interpretação de Dido, que culpou Eneias do seu abandono quando este saiu de Cartago levado pela máo dos deuses.

À imagem da Eneida e da Heróide $7^{13}$, no momento que precede a morte, Dido relembra as façanhas do seu passado heróico, recuperando a dignidade e a coragem que a caracterizam,

${ }^{11}$ A predominância de espondeus dos versos 140, 144 e 145 realça a tristeza das palavras da rainha.

${ }_{12}$ Podemos verificar nesta afirmação a influência do verso 31 da Heróide 7 de Ovídio: parce, Venus, nurui (...). “poupa, Vénus, a tua nora (...)".

${ }^{13}$ Virg. A. 4.656 ss.; Ov. Ep. 7.113 ss.. 
pelo menos antes do encontro com o Troiano. Vingou a morte de Siqueu e velou pela construção de Cartago (8.143-4). Assim, morre na pira uma mulher heróica, consciente do seu valor $(8.145)^{14}$ e da proximidade do reencontro com o seu primeiro marido. É a expectativa deste reencontro que ocupa o pensamento da rainha no momento da morte, como o consolo por que anseia para aliviar a dor causada por Eneias.

É então que trespassa o peito com a espada oferecida pelo Troiano:

Haec dicens ensem media in praecordia adegit, ensem Dardanii quaesitum in pignoris amoris. (8.148-9)

"Dizendo isto, cravou a espada bem no centro do coração, a espada recebida como prova do amor do Dardânida."

Ana descreve, de seguida, a Eneias como ficou perturbada pela morte inesperada da irmá, morte que ela própria ajudara, inconscientemente, a preparar (8.152-156). Ouvindo o rumor de que Jarbas estaria prestes a invadir Cartago, Ana fugiu para Cirene e, posteriormente, o estado alterado do mar trouxe-a para a Itália (8.157-9).

O facto de Ana apresentar os últimos momentos da vida da irmã de forma suave, omitindo qualquer referência à maldição proferida por Dido, é explicada por Ahl 1986: 2497 como uma forma de garantir o auxílio de Eneias: "Anna's intent seems to be both to flatter Aeneas and to stir any feelings of guilt and regret he may have without accusing him of wrongful behavior." Assim, afasta-se, simultaneamente, de Virgílio e de Ovídio, já que não refere nem o desejo de vingança nem as acusaçóes a Eneias.

Terminado o relato da morte de Dido, Ana é acolhida de forma amigável pelo herói (8.163-4), mas a irmã aparece-lhe em sonhos, admoestando-a por estar demasiado confiante e por não se aperceber das armadilhas que Lavínia urde contra ela:

His, soror, in tectis longae indulgere quieti, heu nimium secura, potes? nec, quae tibi fraudes tendantur, quae circumstent discrimina cernis?

${ }^{14}$ Compare-se este verso: nunc ad uos magni descendet corporis umbra "agora, desce para junto de vós o fantasma de uma pessoa de sentimentos nobres." com A. 4.654: nunc magna mei sub terris ibit imago "agora irá para debaixo da terra uma imagem nobre de mim". 
ac nondum nostro infaustos generique soloque

Laomedonteae noscis telluris alumnos?

dum caelum rapida stellas uertigine uoluet, lunaque fraterno lustrabit lumine terras, pax nulla Aeneadas inter Tyriosque manebit.

surge, age, iam tacitas suspecta Lauinia fraudes

molitur dirumque nefas sub corde nolutat. (8.168-77)

"Como podes, irmã, entregar-te nesta casa a um repouso demorado, tranquila em demasia? Não vês que fraudes

são contra ti preparadas nem que perigos te rodeiam?

Não conheces ainda, sinistros para a nossa raça e para os nossos

os discípulos da terra de Laomedonte?

[domínios,

Enquanto o céu fizer girar as estrelas nos seus velozes movimentos

e a lua percorrer a terra com a luz fraterna,

[de rotação, não subsistirá paz alguma entre Enéadas e Tírios.

Levanta-te, vamos! Já Lavínia, desconfiada, urde fraudes em segredo e revolve no seu coração um crime hediondo."

Na versão transmitida nos Fastos de Ovídio, o narrador refere pormenorizadamente as conspiraçóes de Lavínia e a sua má vontade relativamente a Ana, mesmo depois de Eneias recomendar à esposa que a ame como uma irmã:

Vtque domum intrauit Tyrios induta paratus, incipit Aeneas cetera turba tacet:

hanc tibi cur tradam, pia causa, Lauinia coniunx, est mihi: consumpsi naufragus huius opes.

orta Tyro est, regnum Libyca possedit in ora: quam precor ut carae more sororis ames.' omnia promittit falsumque Lauinia uolnus mente premit tacita dissimulatque metus; donaque cum uideat praeter sua lumina ferri multa, tamen mitti clam quoque multa putat. non habet exactum quid agat: furialiter odit, et parat insidias et cupit ulta mori. (Fast. 3.627-38)

"Assim que entrou em casa, vestida à maneira Tíria, começa a falar Eneias, depois de os outros se calarem:

'A razão, esposa Lavínia, por que te confio esta mulher é piedosa: como náufrago consumi os seus bens. Nasceu em Tiro, possui um reino na costa líbica. 
Peço-te que a ames como se fosse uma irmã querida'.

Tudo ela promete e uma ferida enganadora esconde na mente, em silêncio, e dissimula o medo; E como vê que, à sua vista, são levados muitos presentes [a Ana], pensa que às ocultas lhe são enviados outros tantos.

Não sabe bem o que fazer: odeia furiosamente, maquina insídias e deseja morrer depois de se ter vingado."

A reacção de Lavínia à chegada de Ana é bastante negativa. Ovídio mostra a esposa de Eneias afrontada pelo acolhimento prestado a Ana, que inveja os presentes que a esta são oferecidos. Odiando-a irracionalmente, furialiter (8.637), deseja vingar-se de Ana. O pormenor com que se define a atitude de Lavínia intensifica a descrição desabonatória do carácter da esposa de Eneias. Quando o fantasma da irmá aparece a Ana é apenas para a aconselhar a fugir do palácio do Troiano:

\section{Nox erat: ante torum uisa est adstare sororis squalenti Dido sanguinulenta coma et 'fuge, ne dubita, maestum fuge' dicere 'tectum'; sub uerbum querulas impulit aura fores. (Fast. 3.639-42) \\ "Era noite: viu-se à frente do leito da irmã, em pé, Dido, coberta de sangue, com os cabelos em desalinho e que dizia: 'Foge sem hesitar, foge desta casa sinistra'. $\mathrm{E}$ ao pronunciar estas palavras, a brisa empurrou as}

[portas gemebundas."

Em Sílio Itálico, pelo contrário, é Dido quem avisa Ana dos perigos que a esposa de Eneias prepara contra ela. É Dido quem dá voz a estas suspeitas, fazendo, assim, com que não seja o narrador a pôr em causa a conduta de Lavínia. Deste modo, evita obscurecer a caracterização positiva dos valores romanos. $\mathrm{O}$ facto de ser Dido a chamar a atenção da irmã para as ameaças que a rodeiam dá continuidade à desconfiança e à hostilidade sentida pela rainha de Cartago em relação a Eneias e aos seus familiares e descendentes. A cólera, o desejo de vingança e a impossibilidade de uma reconciliação entre os povos são, assim, sentimentos que caracterizam os Cartagineses, herdeiros da hostilidade gerada por Dido. É, por isso, necessário que a rainha censure a irmã por esta se sentir protegida junto de Eneias. É necessário que, uma vez mais, a recorde das implicaçóes do seu encontro com Eneias e das suas últimas palavras. Não pode existir convivência pacífica entre 
os dois povos (8.71-5). E Dido aparece nos sonhos de Ana para lhe lembrar que também ela é uma Cartaginesa e deve cumprir as recomendações da irmã. É por esta razão que Ana é escolhida por Juno para dar coragem a Aníbal: porque, como irmã de Dido e descendente de Belo ${ }^{15}$ (8.221), como cidadá de Cartago, deve fazer perdurar o desejo de vingança que é o legado deixado pela rainha aos Cartagineses. A resposta de Aníbal é o reconhecimento da função de Ana como intermediária do ódio da irmã, já que lhe promete consagrar num templo de mármore a imagem de Ana juntamente com a de Dido, unindo, deste modo, as duas irmãs enquanto inspiradoras do ardor guerreiro que o impele a atacar e a invadir Roma ${ }^{16}$.

Ainda que recupere a interpretação virgiliana do encontro de Dido e Eneias como a causa da hostilidade entre Cartagineses e Romanos, Sílio Itálico incorpora, no entanto, elementos da caracterização de Dido na obra de Ovídio, elaborando, deste modo, de forma inovadora, a fusão entre as versôes anteriores. Se o contexto épico retoma a violência que caracteriza os últimos momentos da vida da rainha na Eneida, a influência da versão ovidiana torna-se evidente na lenda de Ana, que é a referência mais extensa à história da rainha, não sem algumas alteraçóes que tornam inócuos alguns elementos presentes em Ovídio. De qualquer modo, a transformação mais significativa é a que sofre Eneias que, contrariamente ao que demonstram as versóes anteriores, assume abertamente e sem as preocupaçóes que o caracterizavam o amor pela rainha. Esta alteração absolve o Troiano das acusaçôes de que é vítima na obra de Ovídio e que são insinuadas, sem que ele se defenda com sucesso, na Eneida. Eneias, o antepassado dos Romanos, náo poderia ser o exemplo das virtudes destes, se fosse responsável pelos delitos de que a rainha o acusava, nomeadamente o de ter violado o compromisso com ela assumido. Deste modo, aparece perante os olhos do leitor uma nova dualidade. Dido continua a sentir-se traída e

${ }^{15}$ Belo, rei de Tiro, era pai de Dido e Ana. Também Asdrúbal, irmão de Aníbal, recorre ao parentesco que o une a Dido para exortar ao combate os seus homens em fuga, durante a batalha de Metauro (15.744-7).

${ }^{16}$ É também o nome de Dido que Aníbal invoca quando abandona a Itália, contrariado e olhando para trás, enquanto todos os seus companheiros contemplam a extensão do mar à sua frente. Amaldiçoando a decisão de ter partido, exclama: flagrasset subdita taedis / Carthago, et potius cecidisset nomen Elissae. (17.223-4) "antes Cartago, dominada, tivesse sido consumida pelas chamas dos archotes e tivesse perecido, Elissa, o teu nome". 
abandonada por Eneias, mas este, pela primeira vez, é inocente. Deixamos, assim, de ter uma vítima e um criminoso, ou uma vítima e um herói abnegado que segue fiel e inexoravelmente o seu destino. Na verdade, a culpa foi dos deuses...

$\mathrm{O}$ ódio que brota do anátema lançado por Dido sobre os dois povos em conflito baseia-se, assim, num mal-entendido, na incompreensão de Dido, que náo percebeu até que ponto os deuses intervieram na partida de Eneias. Devido ao despeito de uma mulher que se ofendeu sem ter razóes válidas para isso, devido à cegueira do amor por ela acalentado, por causa desta mulher e do ódio visceral que ela transmite aos seus descendentes, os Romanos - descendentes de um Eneias que não teve responsabilidade alguma por esse ódio, que, pelo contrário, estava feliz ao lado dela e partiu contrariado, que foi transportado pela máo dos deuses têm de suportar e refrear a demência dos Cartagineses. 
Capítulo IV

A resposta aos mestres: a versão da "Casta Dido" 
Ainda que a versão virgiliana tenha alcançado a preferência do público, preferência já referida por Ovídio (Tr. 2.535-6), o papel de Virgílio como "inventor" ou "adaptador" do mito, pelo menos no que diz respeito ao encontro de Dido e Eneias e à consequente polémica de índole moral, não deixa de ser reconhecido em várias fontes. De acordo com Hexter 1992: 338-9, pelos menos os primeiros intérpretes da Eneida (leitores ou ouvintes) ter-se-iam apercebido da estranheza da história de Dido, tal como modelada por Virgílio, já que em nenhum relato histórico da fundação de Roma se refere o encontro entre Dido e Eneias.

Em Saturnalia 5.17, Macróbio afirma que a versão virgiliana foi tão apreciada que ofuscou a versão que todos conheciam como a verdadeira história de Dido:

(...) quod ita elegantius auctore digessit, ut fabula lasciuientis Didonis, quam falsam nouit uniuersitas, per tot tamen saecula speciem ueritatis obtineat (...).

“(...) porque se afastou de tal maneira e com tanta elegância do criador, que a história da devassa Dido, que o mundo inteiro sabe ser falsa, manteve durante tantos séculos o aspecto de ser verdadeira."

A "mentira” de Virgílio foi tão bem elaborada que passou a ser preferida à verdade e, de acordo com o mesmo autor, despertou tanto interesse que inspirou os artistas como nenhum outro tema ${ }^{1}$. A pulchritudo narrandi com que Virgílio embelezou a sua Dido encantou os leitores da Eneida, a tal ponto que estes a preferem ao reconhecimento da castidade da rainha, esquecendo a impossibilidade cronológica do seu encontro com Eneias:

Tantum ualuit pulchritudo narrandi, ut omnes Phoenissae castitatis conscii, nec ignari manum sibi iniecisse reginam, ne pateretur damnum pudoris, conniueant tamen fabulae; et intra conscientiam

${ }^{1}$ Macróbio informa-nos também da influência da personagem nos enredos das pantomimas que exploravam o carácter trágico da versão virgiliana:. nec minus histrionum perpetuis et gestibus et cantibus celebretur (5.17) "não é menos celebrada nos gestos e nos cantos perpétuos dos actores". 
ueri fidem prementes malint pro uero celebrari quod pectoribus bumanis dulcedo fingentis infudit. (5.17.6)

"A tal ponto prevaleceu a beleza da narraçáo que todos, conhecedores da castidade da Fenícia e não ignorando o facto de a rainha ter atentado contra a sua própria vida para não ter de suportar que se difamasse a sua honra, são, ainda assim, indulgentes para com a história e, oprimindo dentro da consciência a fidelidade que é devida à verdade, preferem em vez da verdade divulgar o que o encanto de quem inventou [a história] introduziu nos coraçóes humanos."

Macróbio reconhece, assim, o poder da poesia virgiliana e as consequências do prestígio desta, especialmente no que diz respeito à obnubilação da verdadeira história de Dido, conservada nos relatos de historiógrafos como Timeu e Justino, que situam a vida da rainha de Cartago longe do espaço lendário que subjaz à fundação de Roma.

A versão mais antiga da história de Dido é divulgada por Timeu de Tauroménio (FGrH. 3b.566.82; cf. texto e tradução, Anexo I), historiógrafo do século IV-III a. C., cuja obra sobrevive apenas em fragmentos. A sinopse da vida da rainha resume-se à fuga da Fenícia, após a morte do marido - cujo nome não é referido - às mãos de Pigmaliáo, irmáo daquela e rei dos Tírios. Colocando algumas riquezas numa embarcação, Dido fugiu com alguns concidadãos e fundou Carquédon, na Líbia, depois de uma viagem atribulada. $\mathrm{O}$ fragmento conserva também a explicação dos dois nomes da rainha. Dido foi o nome que os Líbios lhe atribuíram, por causa da sua viagem, Elissa era o seu nome na língua fenícia, e, portanto, o seu verdadeiro nome. Timeu descreve ainda de forma resumida a morte de Dido, que se terá suicidado para evitar o casamento com o rei dos Líbios. Tendo mandado construir uma pira dentro de casa, lançou-se sobre ela.

Os factos mais importantes do relato de Timeu resumem-se, assim, à fuga da Fenícia e à consequente fundação de Cartago e ao suicídio como forma de escapar ao casamento com o rei dos Líbios. Ainda que se detenha na explicação dos nomes de Dido, a concisão do fragmento omite grande parte da história, não permitindo, deste modo, uma visão mais completa da versão de Timeu.

Afirma, a este respeito, Davidson 1998: 67: "The question of what else was included in Timaeus' account takes us further into the realms of speculation, but there are strong indications that he 
was drawing on a coherent and more or less consistent account centred on Dido (...)". Acrescenta ainda que Justino, autor de data incerta, provavelmente do século II ou III d. C., que reduziu a uma epítome a obra Historiae Philippicae de Trogo Pompeio, historiador da época de Augusto, conserva a versáo mais completa desta tradição. De facto, Justino transmite o relato mais longo e pormenorizado das peripécias da história de Elissa ${ }^{2}$, desde as circunstâncias que a fizeram partir da Fenícia até à sua morte, em Cartago (cf. tradução, Anexo I).

Justino identifica-a como filha de Mutto, rei de Tiro, irmã de Pigmalião, seu irmão mais novo, e esposa do seu tio materno, Acherbas, sacerdote de Hércules e o homem mais importante de Tiro, a seguir ao monarca. Depois de este ter sido assassinado impiamenteporPigmaliáo, Elissaescondedoirmãoo ressentimento que por ele nutria, para poder preparar a fuga (4.9), e reúne alguns cidadãos que desejavam partir. Finge querer mudar-se para casa de Pigmalião, sob o pretexto de mais facilmente esquecer a morte de Aquerbas (4.10). Pigmalião, desejando apoderar-se das riquezas do marido da irmá, disponibiliza-se para a acolher. Quando Elissa se prepara para partir supostamente para a casa do irmáo, obriga os delegados que tinham sido enviados pelo rei para a ajudar na mudança a lançar ao mar sacos de areia, enquanto exorta o marido a receber as suas riquezas (4.12-13). Os enviados de Pigmalião, com medo de regressarem, juntam-se ao séquito de Elissa e partem para o exílio (4.14-15).

Desembarcam em Chipre, onde Elissa ordena o rapto de oitenta virgens (5.5), para garantir o futuro da comunidade que então dirige. Já em África, Elissa compra um espaço de terra que pudesse ser coberto com a pele de um boi, que corta em tiras finas para abarcar mais terreno do que solicitara - é o famoso estratagema da pele de boi, que imortalizou a astúcia da rainha (5.8-9).

Depois da fundação da cidade, Hiarbas, rei dos Maxitanos, convoca alguns cidadáos de Cartago e comunica a sua pretensão de casar com Elissa, caso contrário seria declarada a guerra entre os dois povos. Amedrontados, os Cartagineses preparam uma armadilha à rainha, para que esta não tenha forma de recusar a proposta. Dizem-lhe que Hiarbas quer que um dos Cartagineses civilize o seu povo, e, dolosamente, insinuam perante a rainha que Elissa.

${ }^{2}$ Justino designa Dido não por este nome, mas pelo seu nome fenício, 
ninguém quereria viver no meio de um povo de bárbaros. Elissa responde que qualquer cidadão cartaginês tem a obrigação de se sacrificar pela pátria e assim, vítima das suas próprias palavras, é moralmente obrigada a aceitar casar-se com o rei. Resignada, pede um prazo de três meses e manda preparar um sacrifício para aplacar os manes do seu defunto marido, mas é ela própria quem, empunhando a espada, sobe para a pira, gritando para o seu povo que ia juntar-se ao esposo.

A historiografia refere-se, assim, a Dido como a heroína fundadora de Cartago, sendo a sua história um exemplum de coragem e astúcia, tanto mais admirável quanto desempenhado por uma mulher. Pela sua morte mantém-se fiel à memória do marido, mas, acima de tudo, continua indomável e senhora do seu destino. Na versão transmitida por Justino, Elissa é uma rainha venerada pela altivez e coragem que caracterizam os seus actos. De facto, o carácter heróico da fundadora de Cartago é o principal traço distintivo da versáo de que nos ocupamos e define não apenas a fuga de Cartago e a viagem para a Líbia, mas também o modo como a rainha póe termo à sua vida para evitar um segundo matrimónio.

Enquanto Timeu refere apenas a morte pelo fogo, Justino descreve o suicídio da rainha de forma mais teatral: lança-se sobre a pira e, antes de se trespassar com a espada, dirige algumas palavras à multidão (6.6-7). Desmond 1994: 26 acentua o aspecto nobre da morte pela espada, a morte do herói por excelência. Deste modo, Elissa escolhe morrer heroicamente, ultrapassando os limites da natureza humana de tal forma que, depois de morta, foi venerada pelo seu povo como uma divindade (6.8). Elissa é, assim, uma mulher que demonstra uma força notável ao conduzir o seu povo e a sua vida.

Apesar de, na Eneida (A. 1.343ss.), Vénus relatar a Eneias os acontecimentos do passado de Dido que a levaram a abandonar a Fenícia e a fundar Cartago, retomando, assim, a versão conservada pelos historiógrafos, o subsequente encontro com o Troiano e a relação entre ambos afastam Dido das características que a definem essencialmente como $d u x$, como líder, e como heroína fundadora de Cartago. Se sobressaem do relato de Vénus os incidentes que a morte de Siqueu provocou, bem como a dedicaçáo que Dido votava ao marido ( $A$. 1.344) e, de forma mais lacónica, a astúcia da rainha, o certo é que o papel de Dido como mulher corajosa é propositadamente atenuado. Perante Eneias interessa realçar 
o sofrimento experimentado por Dido ao ver-se violentamente privada de Siqueu e forçada a abandonar Tiro, para que Eneias reconheça na rainha um ser com um passado semelhante ao seu.

Sérvio, no comentário ao verso 4.36 da Eneida, a propósito da recusa de Dido em casar com Jarbas, apresenta um pequeno resumo da versão transmitida por Justino:

Despectus Iarbas rex Libyae, qui Didonem re uera uoluit ducere uxorem et, ut habet historia, cum haec negaret, Carthagini intulit bellum. Cuius timore cum cogeretur a ciuibus, petiit ut ante placaret manes mariti prioris, et exaedificata pyra se in ignem praecipitauit: ob quam rem Dido, id est uirago, quae uirile aliquid fecit appellata est; nam Elissa proprie dicta est.

"Jarbas, rei da Líbia, queria casar com Dido e, como conta a história, como esta o recusasse, por ter sido desprezado, declarou guerra a Cartago. Obrigada pelos cidadãos que tinham medo daquele, pediu que antes lhe permitissem aplacar os manes do anterior marido e, tendo construído uma pira, lançou-se no fogo. Por esta razão, foi designada Dido, isto é virago, porque fez algo viril. Na verdade, o seu nome verdadeiro é Elissa."

A explicação do nome Dido como "virago" retoma a caracterização da rainha como uma mulher de coragem ímpar ${ }^{3}$, caracterização parcialmente presente na Eneida, nomeadamente na associação da rainha a figuras femininas definidas pela força e pela transgressáo de características que se consideram adequadas ao sexo feminino, como Diana ou Pentesileia. Desmond 1994: 28 define a transformação sofrida por Dido na Eneida como uma sexualizaçáo. De facto, é o encontro com Eneias que faz com que a rainha esqueça o seu passado heróico e as suas obrigaçóes enquanto monarca: "Aeneid 4 departs from the historical tradition

${ }^{3}$ Em Octávio, 20.6, Minúcio Félix parece ter Dido em mente quando afirma: (...) unaquaeque natio conditorem suum aut ducem inclitum aut reginam pudicam sexu suo fortiorem (...) uenerabatur ut ciuem bonae memoriae: sic et defunctis praemium et futuris dabatur exemplum. (...) cada nação venerava, como cidadão de perpétua memória, o seu fundador, ou um chefe célebre, ou uma respeitável rainha dotada de uma fortaleza superior à das pessoas do mesmo sexo (...) desta forma, proporcionava-se uma recompensa aos defuntos e um exemplo aos vindouros.”) (trad. Silva 1990:122-3). Realça, assim, não apenas a castidade da rainha, mas também a força que a aproxima do sexo masculino e o carácter exemplar da sua história. Para uma sinopse das explicaçóes dos dois nomes da rainha, cf. Moya del Baño 1969: 74-5. 
in its treatment of Dido as a sexualized figure, a woman tempted by amor to forsake both her oath to Sychaeus (which the historical Dido died to preserve) and her role as leader."

A oposição entre a versão dos historiógrafos e a virgiliana está na base de textos como o epigrama 151 da Antologia de Planudes, de que o epigrama 45 dos Epigrammata Bobiensia atribuído, por vezes, a Ausónio ${ }^{4}$, é uma reelaboração ${ }^{5}$ (cf. tradução de ambos os poemas, Anexo I). Nestes textos, é a própria Dido quem se defende das características desabonatórias que Virgílio lhe confere na Eneida, contrapondo às mentiras inventadas que a relacionam com Eneias a verdade histórica, que justifica o seu suicídio como reacção às intençôes matrimoniais de Jarbas ${ }^{6}$. A personagem declara-se inocente dos desejos criminosos que Virgílio inventou, já que nem sequer conheceu Eneias e morreu, náo por causa da partida deste, mas para evitar a guerra com que Jarbas ameaçou os Cartagineses e com a finalidade de fugir ao matrimónio. Assim, a sua morte foi um estratagema para manter a castidade e a reputaçáo incólumes. A ferida que lhe causou a morte foi apenas a que a espada abriu, pois nem o furor nem a dor de um amor rejeitado a atingiram. Anulada a ambiguidade da ferida do amor, Dido morre por uma ferida real, morre com a altivez com que Eneias a conheceu quando chegou a Cartago. A recordação das suas façanhas é a mesma que evoca na Eneida, no derradeiro momento:

Vrbem praeclaram statui; mea moenia uidi;

Vlta uirum, poenas inimico a fratre recepi. (A. 4.655-6)

"Construí uma cidade ilustre, vi as muralhas que mandei construir; Vinguei o meu marido, castiguei o meu irmão inimigo."

${ }^{4}$ Ausonius Burdigalensis Epigrammata XC (PL XIX, 835).

5 A Antologia de Planudes, compilada por volta de 1300 pelo monge bizantino Máximo Planudes, conserva uma série de poemas da Antologia Grega não transmitidos pelo Palatinus Heidelbergensis gr. 23. A Antologia Grega recolhe uma grande variedade de poemas datáveis dos séculos VII a. C. a X d. C.. Aubreton 1980, Poinsotte 1990: 52, n. 54 e Horsfall 1990: 138 consideram o texto dos Epigrammata Bobiensia, compilaçáo de poemas dos séculos III a IV d. C., uma adaptação do texto anónimo transmitido pela Antologia de Planudes.

" O mesmo tema é apresentado no soneto "À constância de Dido" de Bocage: Mentes, mentes, injusto mantuano! / Dido infeliz foi vitima do esposo, I Foi vítima da fé, não do troiano. 
Quando na épica de Virgílio, depois das peripécias do encontro desventurado com o Troiano, Dido lamenta que as naus de Eneias tenham aportado à Líbia, amaldiçoa também a mudança que se operou no seu destino. É como se, revoltando-se contra o seu criador, a própria personagem tomasse a iniciativa de repor a verdade - leia-se: a verdade dos historiadores. A poesia virgiliana assume, assim, o carácter de uma mentira que Dido denuncia abertamente nos epigramas analisados. Esta denúncia, este contrapor de duas tradiçôes, encontra justificação no êxito conseguido pela versão virgiliana, como afirma Hexter 1992: 340: “(...) what we, under Vergil' s spell, now call the 'other' tradition, was in the end only repeated and recorded because it contradicted Vergil, who had finally succeeded in making his tradition 'the one'."

A impossibilidade cronológica de Dido e Eneias se terem encontrado, reconhecida por Sérvio (A. 1.267, 4.459), e a injustiça da invenção virgiliana caracterizam, assim, uma série de textos que recuperam a versáo dos historiógrafos. Assumindo esta perspectiva, autores cristãos como Tertuliano e S. Jerónimo procedem à defesa da castidade de Dido, que, tendo-se suicidado para escapar às intençóes matrimoniais de Jarbas, contraria a versão virgiliana. A personagem serve, assim, a doutrina cristã sob a égide da qual estes autores elaboram uma série de consideraçóes relativas à conduta da mulher e ao seu papel na salvação do Homem.

Como preparação para o fim dos tempos, a castidade feminina torna-se essencial e o casamento desnecessário. Por este motivo, de acordo com Tertuliano, as mulheres viúvas e solteiras serão as primeiras a ir ao encontro de Deus, já que estáo livres de vínculos afectivos que as prendam ao mundo terreno. Neste contexto, o desejo de contrair segundas núpcias não tem fundamento, já que se devem esconjurar os prazeres da carne com o exercício da castidade e com a entrega à vida espiritual. Esta atitude náo deve ser penosa para os cristáos, se até mulheres pagãs foram capazes de enfrentar destemidamente a morte para se manterem castas. É no âmbito destes preceitos que se deve entender o recurso a exempla pagãos como Dido, Lucrécia e outras: 
“(...) já que também as mulheres menosprezaram o fogo: Dido, para que não a obrigassem a casar novamente depois da morte do marido muito estimado.”

Aliqua Carthaginis conditrix rogo se secundum matrimonium dedit: o praeconium castitatis! (Apologeticum)

"Uma outra, a fundadora de Cartago, entregou-se à pira depois do casamento: ó louvor à castidade!”

Na obra de Tertuliano, Dido apresenta-se imune, longe da ficção virgiliana. É que a versão divulgada pelos historiógrafos pode ser explorada para exemplificar a virtude da castidade, enquanto em Virgílio a ambiguidade moral da rainha, aliada à relaçáo de natureza questionável que mantém com Eneias, a afasta das exigências morais de Tertuliano ${ }^{7}$.

Também S. Jerónimo ilustra a defesa da castidade e da monogamia desejável nas mulheres com o exemplo de Dido, que maluit ardere quam nubere ${ }^{8}$. Se até os pagãos repudiaram a digamia, por que motivo hão-de as mulheres cristâs ansiar pelo casamento? Dido torna-se, assim, um exemplo para estas, devido ao seu estatuto de uniuira e à recusa em contrair segundas núpcias. A versão dos historiógrafos presta-se, deste modo, à regulamentação da sexualidade feminina no âmbito da doutrina cristá.

A recuperação da versão em que Dido não se encontra com Eneias obedece a um interesse ou literário ou de natureza moral. No entanto, a influência da personagem criada por Virgílio mantém-se, mesmo em autores cristáos, como provam as palavras de Sto. Agostinho, penitenciando-se pelas lágrimas derramadas pela morte de Dido:

Quid enim miserius misero non miserante se ipsum et flente Didonis mortem, quae fiebat amando Aenean (...) (Confissóes 1.13)

"Que há de mais triste do que um triste que não se entristece consigo próprio e que chora a morte de Dido por amor a Eneias (...)"

${ }^{7}$ Além dos textos citados, Tertuliano refere Dido como exemplo de castidade e de força no momento de enfrentar a morte em Ad nationes 1.18; De monogamia 17; entre outros. Em Ad nationes 2.9, Tertuliano repudia a veneração da pietas de Eneias, já que este, para salvar o pai e o filho, abandonou Príamo e Astíanax.

${ }^{8}$ Adu. Jouinianum 1.23 (PL XXIII, 273). 
É impossível resistir ao encanto da ficção virgiliana... Também Ausónio se mostrou interessado em Dido. Em Cupido Cruciatus, entre as heroínas que deambulam nos Infernos, descreve a rainha de Cartago:

parte truces alia strictis mucronibus omnes et Thisbe et Canace et Sidonis horret Elissa: coniugis haec, haec patris et haec gerit hospitis ensem. (37-9)

"Noutra parte, todas as mulheres cruéis, de espada desembainhada, Tisbe, Cânace e a Sidónia Elissa eriçando-se:

Uma traz a espada do marido, outra a do pai e a outra a do hóspede."

Dido aparece empunhando a espada, como no momento da morte. No entanto, ainda que o poema tenha inspiração virgiliana - nomeadamente do livro 6 -, adivinha-se o traço de Ovídio na identificação da espada como a espada de Eneias. No livro $6 \mathrm{da}$ Eneida, Dido não tem consigo a espada:

\section{(...) inter quas Phoenissa recens a uulnere Dido errabat silua in magna (...) (A. 6.450-1)}

"Entre estas, recentemente ferida, a fenícia Dido errava num bosque extenso."

A mesma influência ovidiana ecoa no dístico de Ausónio?:

Infelix Dido, nulli bene nupta marito: hoc pereunte fugis, hoc fugiente peris.

"Infeliz Dido, mal casada com ambos os maridos, Morrendo um, foges, fugindo o outro, morres."

Ainda que o adjectivo infelix remeta para a obra de Virgílio, a interpretação da relação de Eneias e Dido como um casamento, ao mesmo nível do casamento com Siqueu, é de inspiração

9 Ausonius Burdigalensis Epitaphia Heroum XXX (PL XIX, 864). Green 1991: 671 considera o epigrama obra de humanistas e não de Ausónio. Bocage traduz este texto do seguinte modo: Quanto és, Dido, desgraçada / Com dois maridos no mundo! / Foges, morrendo o primeiro, / Morres, fugindo o segundo. Também Filinto Elísio dá uma versão do mesmo epigrama: Dido, nas bodas triste fado corres: / Morre-te um, foges, foge-te outro, morres. 
ovidiana. Também a caracterização da partida de Eneias como uma fuga, embora tenha antecedentes nas acusações de Dido na Eneida (A. 4.314), reflecte com mais exactidão o tom delatório predominante na Heróide 7.

Os primeiros séculos que marcam a pervivência da personagem estabelecem, assim, o certame entre as versóes de Virgílio e de Ovídio. Assiste-se ainda ao ressurgir da tradição histórica que afasta Dido do espaço lendário e mitológico da fundação de Roma, apresentando a personagem em contextos divergentes dos modelos. Poinsotte 1990: 53 explica a importância concedida à versão que apresenta Dido como uma mulher de carácter heróico e moralmente irrepreensível como uma forma de reagir à importância assumida pela versão virgiliana: “C'est de la chaste Didon que l' Antiquité tardive a parlé avec le plus d' insistance. Mais cette insistance même est suspecte, elle nous amène à nous demander si la plus vivante des deux n'était pas celle dont on parlait le moins, l'indésirable dont on ressentait d'autant plus fortement la nécessité de l'oublier qu'il était bien difficile de le faire." A casta Dido surge, assim, como forma de responder ao prestígio da Dido virgiliana. 


\section{Anexo}

Timeu de TAuroménio (FGrH. 3b.566.82)

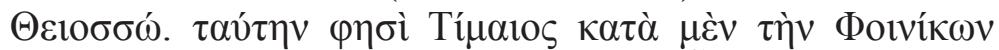

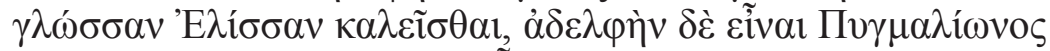

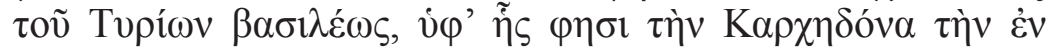

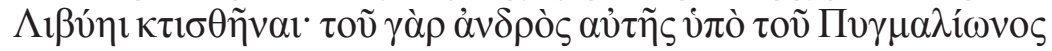

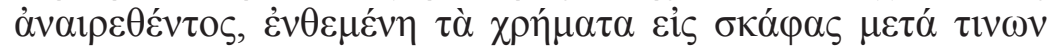

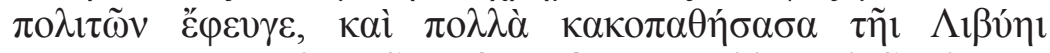

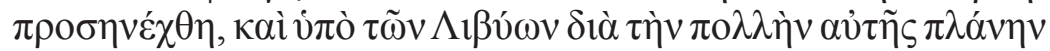

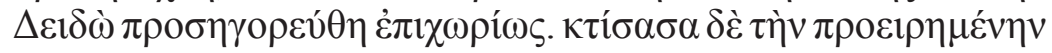

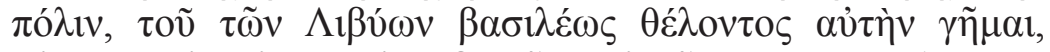

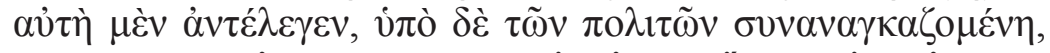

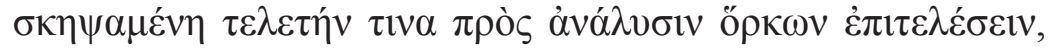

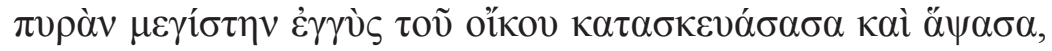

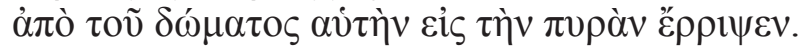

"Theiosso. Timeu diz que esta se chamava Elissa na língua dos Fenícios, que era irmã de Pigmaliāo, rei dos Tírios e que Cartago, na Líbia, foi fundada por ela. Quando o seu marido foi assassinado por Pigmaliáo, ela, colocando as suas riquezas a bordo de embarcaçôes, fugiu com alguns cidadãos e enfrentando muitas adversidades, aportou à Líbia. Por causa das suas muitas errâncias os Líbios chamam-na Dido na sua língua indígena. Depois de ter procedido à construção da cidade anteriormente mencionada, querendo o rei dos Líbios casar-se com ela, ela recusou. Obrigada pelos cidadãos, fingiu que celebrava a libertação das suas promessas, edificou perto de casa uma grande pira e tendo-a incendiado, lançou-se de dentro de casa para cima dela."

\section{Justino, Epitoma Historiarum Philippicarum Pompei TROGI, LIBER XVIII}

[4] 3. Quando, neste tempo, em Tiro, o rei Muto morreu, foram declarados seus herdeiros o filho, Pigmalião, e a filha, Elissa, uma jovem de notável beleza. 4. O povo, todavia, confiou o poder a Pigmaliáo, ainda criança. 5. Elissa casou com Aquerbas, seu tio materno, sacerdote de Hércules, o cargo mais importante a seguir ao rei. 6. Aquerbas possuía muitas riquezas, mas escondidas. Com medo do rei escondera o ouro náo em casa mas debaixo da terra. 7. Ainda que as pessoas ignorassem este facto, 
a fama corria. 8. Pigmalião, incitado por esta, esquecido das leis humanas, mata o seu tio, da sua própria família, sem respeito pelas relaçóes familiares.

9. Por causa do crime por ele cometido, Elissa evitou o irmão durante muito tempo. Por fim, disfarçando o ódio e pacificado entretanto o seu aspecto, prepara em segredo a fuga. Associa-se a algumas pessoas importantes que julgava nutrirem pelo rei um ódio semelhante ao seu e a mesma vontade de fugir. 10. Aproxima-se então dolosamente do irmão, finge querer mudar-se para casa dele para que a casa do marido náo continuasse a renovar nela, desejosa de esquecer, a lembrança dolorosa da morte [do marido] e para que náo mais se apresentasse perante os seus olhos a penosa recordação deste. 11. Não foi sem agrado que Pigmalião ouviu as palavras da irmá, pensando que com ela viria também o ouro de Aquerbas.

12. Mas, ao cair da tarde, Elissa embarca nas naus os ajudantes, enviados pelo rei para efectuar a mudança, e todas as riquezas que possuía. Depois de se ter dirigido para o mar alto, obrigaos a lançar ao mar sacos de areia embrulhados que se pensava serem sacos de dinheiro. 13. Então, enquanto chora, chama com uma voz triste Aquerbas. Pede-lhe que receba de boa vontade as riquezas que lhe pertencem e que deixou e que as aceite como uma oferta votiva já que foram a causa da sua morte. 14. Então dirige-se aos próprios enviados do rei, diz-lhes que ela já há muito deseja a morte, mas a eles esperam-nos torturas cruéis e suplícios terríveis, eles que desviaram da cobiça do tirano, que cometera parricídio com a esperança de delas se assenhorear, as riquezas de Aquerbas. 15. Tendo assim incutido neles o medo, acolheu-os como companheiros de fuga. Juntam-se-lhes também imensos senadores, que previamente tinham combinado reunir-se naquela noite e assim, tomando os objectos sagrados de Hércules, deus de quem Aquerbas tinha sido sacerdote, procuram um lugar para o exílio.

[5] 1. O primeiro lugar em que desembarcaram foi a ilha de Chipre. 2. Aí, o sacerdote de Júpiter, juntamente com a esposa e os filhos, aconselhado a isso pelos deuses, juntou-se a Elissa como companheiro e aliado, pedindo que se estabelecesse para sempre, para si e para os seus descendentes, o cargo de sacerdote. 3. Pela evidência do augúrio a condição foi aceite. 4. Era costume dos Chipriotas enviar antes do casamento, em dias marcados, as jovens para a beira-mar para ganharem dinheiro para o dote, a fim 
de pagarem a Vénus pelo resto da sua castidade. 5. Destas Elissa ordena que sejam raptadas e embarcadas cerca de oitenta jovens, para que a juventude pudesse casar e a cidade ter posteridade.

6. Enquanto estas coisas acontecem, Pigmalião tendo conhecimento da fuga da irmá e preparando-se para a perseguir com uma guerra impiedosa, foi a custo apaziguado, vencido pelas preces da mãe e pelas ameaças dos deuses. 7. Uma vez que profetas inspirados lhe prediziam que não ficaria impune se perturbasse a fundação de uma cidade que haveria de ser a mais auspiciosa de todo o mundo, foi deste modo possível que os fugitivos tivessem tempo para recuperarem. 8. E assim Elissa é trazida até uma enseada na África e procura a amizade dos habitantes desse lugar, animados pela chegada de estrangeiros e pela possibilidade de relaçóes comerciais. 9. Depois, tendo adquirido o espaço que pudesse ser abrangido por uma pele de boi, onde os companheiros cansados devido à longa navegação pudessem descansar até partirem de novo, ordena que a pele de boi seja cortada em tiras finíssimas e, deste modo, ocupa um espaço maior do que aquele que pedira. Foi por este facto que foi dado depois a este lugar o nome de Byrsa. 10. Acorrendo os vizinhos, que, pela esperança do lucro traziam muitas coisas para vender aos estrangeiros, 11. estabeleceram-se aí por causa da afluência de pessoas como se se tratasse de uma cidade. 12. Embaixadores de Útica trouxeram também presentes por se tratar de pessoas com a mesma origem e aconselharam-nos a fundar uma cidade no local que a sorte lhes indicasse. 13. Mas a vontade de deter os estrangeiros tomou conta dos Africanos. 14. E assim, com o consentimento de todos, fundou-se Cartago estabelecendo-se um imposto anual pelo solo da cidade.

15. Na escavação dos primeiros alicerces encontrou-se uma cabeça de boi, presságio de fertilidade mas também de uma cidade que haveria de viver entregue a trabalhos duros e para sempre subserviente. Por este motivo mudou-se a localização da cidade para outro lugar, 16. onde se encontrou uma cabeça de cavalo, que significava que o povo haveria de ser aguerrido e poderoso. Isto indicou o local favorável para construção da cidade. 17. Então, acorreram multidóes de pessoas por terem ouvido falar da nova cidade e em breve o povo e a cidade cresceram.

[6] 1. Uma vez que com o êxito dos acontecimentos os recursos de Cartago cresciam, Jarbas, rei dos Maxitanos, tendo convocado dez dos cidadáos púnicos mais importantes, pediu 
Elissa em casamento sob a ameaça da guerra. 2. Os enviados, temendo transmitir esta informação à rainha, agiram com ela utilizando o engenho púnico. Disseram-lhe que o rei lhes pedia alguém que lhe ensinasse a ele e aos Africanos hábitos civilizados. 3. Mas que pessoa poderiam encontrar que quisesse deixar a sua família e passar a viver entre bárbaros, com pessoas que viviam como os animais selvagens? 4. Então, repreendidos pela rainha por recusarem viver em condiçóes adversas em prol da segurança da pátria à qual até a própria vida, se as circunstâncias o exigissem, era devida, eles revelaram as indicaçóes do rei, dizendo que o que prescrevia aos outros devia ser feito também por ela, se quisesse agir em prol da cidade.

5. Vencida com este dolo invocou durante muito tempo o nome do marido Aquerbas, entre muitas lágrimas e lamentaçóes. Por fim, respondeu que iria para onde o seu destino e o da cidade a reclamassem. 6. Tendo-se estabelecido um prazo de três meses para cumprir esta resoluçáo, mandou construir uma pira numa parte remota da cidade, como se quisesse aplacar a alma do marido e oferecer em sacrifício, antes do casamento, as muitas vítimas que matou e, tomando consigo a espada, subiu para a pira. 7. Voltando os olhos para o povo, disse que era assim que partia para junto do marido, como lhe tinham ordenado, e com a espada pôs fim à sua vida. 8. Enquanto Cartago permaneceu invencível, foi venerada como uma deusa.

\section{Antologia de Planudes, 151}

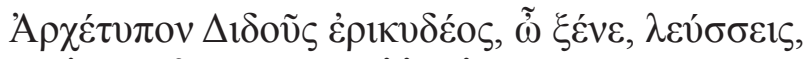

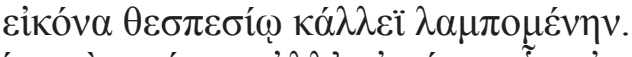

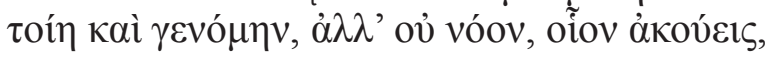

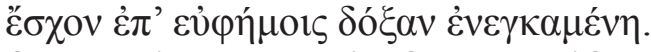

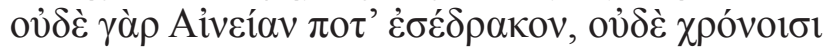

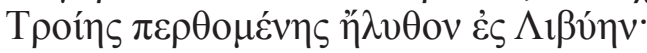

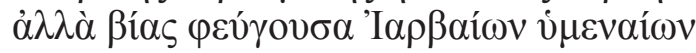

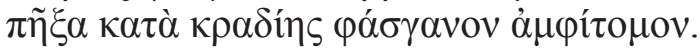

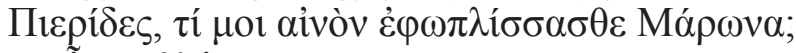

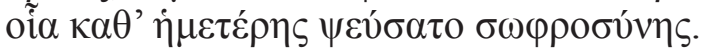

"A imagem que contemplas, estrangeiro, é a imagem

[verdadeira da ilustre Dido, que brilha com uma beleza divina. 
Eu tinha este aspecto, mas sem a mente que ouves dizer [que eu tinha. Esforçava-me por atingir a glória com palavras sensatas.

É que eu jamais pus os olhos em Eneias, nem ele veio para a Líbia quando Tróia foi destruída.

Mas fugindo a um casamento forçado com Jarbas enterrei no meu coração uma espada de dois gumes.

Piérides, por que preparastes contra mim o inocente Marão, que inventou mentiras acerca da minha honra?"

\section{EPIGRAMMATA BoBIENSIA, 45}

In Didus imaginem

Illo ego sum Dido uultu, quem conspicis, hospes, Assimilata modis pulchraque mirificis,

Talis eram: sed non, Maro quam mihi finxit, erat mens:

Vita nec incestis laeta cupidinibus.

Namque nec Aeneas uidit me Troius unquam,

Nec Libyam aduenit classibus Iliacis.

Sed furias fugiens atque arma procacis Iarbae,

Seruaui, fateor, morte pudicitiam,

Pectore transfixo: castus quod perculit ensis,

Non furor, aut laeso crudus amore dolor.

Sic cecidisse iunat: uixi sine uulnere famae.

Vlta uirum, positis moenibus, oppetii.

Inuida, cur in me stimulasti, Musa, Maronem,

Fingeret ut nostrae damna pudicitiae?

Vos magis historicis, lectores, credite de me,

Quam qui furta deum concubitusque canunt

Falsidici uates: temerant qui carmine uerum:

Humanisque deos assimulant uitiis.

"Eu é que sou Dido, viajante, com aquele rosto que observas, reproduzida de modo extraordinário e bela.

Era assim que eu era; mas não tinha a índole que Marão inventou

[para mim,

Nem a minha vida se satisfazia em paixóes ilegítimas.

$\mathrm{Na}$ verdade, nem o Troiano Eneias alguma vez me viu,

Nem aportou na Líbia com a armada de Ílion.

Mas fugindo da cólera e da guerra com o impudente Jarbas,

Preservei, confesso, com a morte a minha honra, 
Trespassando o meu peito, ferido pela espada casta Não pela loucura nem pela dor cruel de um amor ofendido. Foi assim que quis morrer; vivi sem ferir a minha reputação. Vinguei o meu marido, e depois de ter erigido as muralhas da [minha cidade, faleci.

Musa cruel, porque incitaste Marão contra mim

De forma a que inventasse acusaçóes contra a minha castidade? Vós, leitores, acreditai em mim e não nos historiadores Que cantam os crimes e as relaçóes carnais dos deuses, Poetas enganadores, que com os seus poemas profanam a verdade E comparam os deuses aos vícios dos mortais." 
Capítulo V

Entre Virgílio e Ovídio: a Epistula Didonis ad Aeneam 
A Antologia Latina é uma colectânea de materiais heterogéneos, provavelmente reunidos no Norte de África, no século VI d. C. ${ }^{1}$, e transmitidos por um único manuscrito conhecido pelo nome de Codex Salmasianus. Desta colectânea faz parte uma epístola em hexâmetros dactílicos, de autor anónimo, a que alguns editores ${ }^{2}$ deram o título de Epistula Didonis ad Aeneam ${ }^{3}$. Solimano 1988: 35 considera que a obra foi provavelmente composta em África, entre o século III e o IV d. C..

$\mathrm{O}$ texto começa com um prefácio de cinco versos que expóe o tópico literário da modéstia do poeta e em que este solicita a generosidade do leitor para com o seu poema, demostrando, assim, que, retomando o episódio da estada de Eneias em Cartago, se prepara para empreender uma tarefa audaz, ao enfrentar modelos como a Eneida de Virgílio e a Heróide 7 de Ovídio.

Ainda que o remetente da epístola não se identifique directamente, as referências a Cartago e ao destinatário, Eneias, permitem identificar Dido. Nunca no discurso é citado algum dos seus nomes (Dido ou Elissa) e só uma vez se refere a si própria como a rainha de Cartago (130).

O enredo é apresentado de forma bastante resumida (sujeito que se sente ofendido e/ou prejudicado, destinatário que é culpado da ofensa devido à qual o sujeito vai morrer) e, se considerarmos ainda a identificação exígua do remetente, torna-se evidente que o autor pressupóe que o leitor conhece previamente os contornos do episódio. Este conhecimento implica que a interpretaçáo do texto seja feita em confronto com as versóes anteriores.

$O$ facto de o texto se definir como uma epístola associa-o à obra de Ovídio. Todavia, o carácter difuso com que o texto ovidiano se relaciona com o género epistolar torna-se mais preciso na Epistula, já que a própria personagem descreve as dificuldades com que se debate para escrever (15ss.). Acresce o facto de o texto circunscrever o espaço e o tempo da acção, à imagem da Heróide

${ }^{1}$ De acordo com Tarrant 1998r: 9ss..

2 É o caso de Shackleton Bailey 1982 e Solimano 1988, edição que seguimos neste trabalho. Outros, como Riese 1964, dão ao texto o título de Epistula. Dido Aeneae.

${ }^{3}$ Identificada, de seguida, como Epistula, e traduzida em anexo. 
7, e de omitir o elenco de personagens presentes na Eneida, transmitindo apenas a perspectiva de Dido e recuperando, assim, o tom autobiográfico e subjectivo característico da elegia. No entanto, a escolha do hexâmetro dactílico em vez do dístico elegíaco remete-nos, de acordo com Solimano 1988: 27-28, para a epopeia virgiliana, ainda que possa ser entendida como forma de atribuir ao texto a nobreza e a elevação que caracterizam a personagem.

A Epistula partilha ainda com o texto de Ovídio algumas características que definem o entendimento que a rainha tem da sua própria condição. A forma abrupta com que se inicia a estrutura epistolar - não com uma saudação, mas com a afirmação de que o amor ofendido devia obstar a que cumprimentasse o destinatário - retoma um processo já explorado por Ovídio. Manifestando a indignação de Dido, os primeiros versos caracterizam, assim, o seu estado de espírito e estabelecem a dualidade inerente ao género epistolar, que, aqui, se define como a relação entre vítima e culpado (6-7).

Deste modo, Dido inicia o discurso com a informação de que o seu amor foi traído, afirmando-se, no entanto, sem tempo para censuras nem lamentos, já que a reclamam os mortis fata (8-9). Antecipa, assim, o desfecho iminente e atribui a responsabilidade deste a Eneias (9). Por este motivo, a descrição que faz da sua situação, da scribentis imago (Ov. Ep. 7.183)4, baseia-se essencialmente em motivos associados à dor, ao sofrimento e à inquietação psicológica. Chorando e tentando, sem sucesso, apaziguar o choro com as palavras, apresentando-se como sofredora, Dido explora a hesitação em escrever como forma de suscitar misericórdia e de amplificar a sua dor (15-17). O espírito da rainha debate-se entre raiva, dor e amor, sentimentos que a impedem de escrever, de dar forma às iratas... querellas, às 'queixas iradas' (15). O desconcerto que experimenta, dominada por emoções poderosas e contraditórias, transparece, por exemplo, nos poliptotos organizados de forma quiástica no verso $14^{5} \mathrm{e}$ manifesta-se fisicamente:

\section{A, quotiens reuocata manus, dubiumque pependit! quid factura fuit trepidanti pollice! (18-19)}

${ }^{4}$ No texto ovidiano, só nos últimos versos Dido descreve a sua situação enquanto escreve.

${ }^{5}$ Pendet amore dolor, uastus dolor auget amorem. 
"Quantas vezes se deteve a minha mão e ficou suspensa, tremendo-me o polegar, sem saber o que fazer!”

A dor é um obstáculo à escrita, mas, à medida que, a custo, as palavras mal traçadas vão tomando forma, a inquietação adensa-se (24-6). A metáfora virgiliana do fogo devorador, já retomada na Heróide 7 , assume no texto um carácter mais físico do que em Ovídio, já que a própria Dido caracteriza como força desestabilizadora o fogo que lhe invade o corpo $^{6}$. Ela própria classifica o seu amor por Eneias como ardor (131), reconhecendo, deste modo, o poder e a natureza dos sentimentos que nutre pelo Troiano.

Assim, a descrição do amor de Dido retoma vectores essenciais em Virgílio: a agitação psicológica e o fogo da paixão. Ainda no seguimento da versão épica, da inquietação da personagem resulta a incapacidade de dormir (82-3). A perturbação da rainha é, assim, evidente. A alternância no tratamento de Eneias ora pela segunda pessoa, ora pela terceira, também presente em Virgílio e Ovídio, é mais um sinal de perturbação e, ao mesmo tempo, de reconhecimento de que entre ambos não há reaproximação possível. A caracterização da personagem dá, assim, sequência aos traços mais importantes que as versóes anteriores fixaram. No entanto, na Epistula a descriçáo da dor e da indignação provocadas pelo abandono é o principal argumento que Dido utiliza para demover Eneias. Ainda que o perigo da viagem seja outra razão evocada para que este não parta (134-8), é a definição de Dido como vítima que domina o texto. A própria ausência de indicaçóes precisas sobre o seu passado ${ }^{7}$, nomeadamente no que se refere ao desempenho enquanto fundadora da cidade, obedece à intenção de se apresentar como vítima sofredora, como se toda a sua vida se resumisse à relação com o hóspede troiano e ao momento presente, posterior ao abandono. Por este motivo, o objectivo de persuadir Eneias a permanecer em Cartago é pouco

${ }^{6}$ Aproxima-se, assim, mais dos versos virgilianos: caeco carpitur igni ( $A$. 4.2) "é percorrida por um fogo oculto"; Est mollis flamma medullas I interea ( $A$. 4.66-7) "Uma chama devora-lhe entretanto a medula" do que da comparação da Heróide 7.23-4: uror ut inducto ceratae sulpure taedae, / ut pia fumosis addita tura focis. "ardo como os archotes de cera impregnados de enxofre, / †como o incenso sagrado deitado sobre os altares fumegantes.".

7 Só uma vez refere os acontecimentos que antecederam a fundação de Cartago e mesmo a chegada de Eneias, quando, de forma muito concisa, afirma não sofrer tanto como sofreu por causa do irmão (147-8). 
nítido, já que o discurso é mais um lamento do que uma tentativa de persuasão e a finalidade de convencer Eneias, se existe, é difusa e mal articulada, baseando-se principalmente na descrição da dor como forma de captatio misericordiae (Solimano 1988: 23).

A descrição psicológica que ela própria elabora serve o objectivo de a caracterizar como a parte injustiçada da relação com Eneias. No entanto, ainda que esta descrição não inclua a cólera desenfreada que na épica virgiliana leva Dido a desejar vingar-se e a profetizar a inimizade eterna entre os Cartagineses e os descendentes de Eneias, também na Epistula Dido lamenta não ter despedaçado Eneias e Ascânio (91-6). O pormenor com que descreve o que poderia ter feito a ambos afasta-a, à primeira vista, dos sentimentos misericordiosos da personagem ovidiana. A serenidade com que, todavia, rejeita a hipótese do assassínio de ambos provoca uma espécie de equilíbrio entre as duas versóes anteriores (96-100). Deste modo, a expressáo da piedade da rainha é amplificada pelo facto de afirmar ter podido vingar-se e não o ter feito. Dido escolhe, assim, entre as versóes de Virgílio e de Ovídio, rejeitando a reacção cruel da primeira e optando pelo estatuto de vítima indefesa e inócua que caracteriza a segunda. No entanto, o facto de referir a possibilidade de ter cometido um acto vingativo afasta-a da versão ovidiana, sem, porém, a aproximar de Virgílio. Deste modo, a rainha dá uma nova dimensão não apenas ao seu amor mas também ao seu carácter, já que enfatiza a renúncia ao uso da violência, demonstrando assim como, ainda que tenha sido vítima de um repúdio que não merece, ainda que tivesse poder para destruir Eneias, optou deliberadamente por não o fazer.

Dido explora também os sentimentos que nutre por Ascânio para mostrar a sua generosidade (106-10). Com menor intensidade do que na Eneida e na Heróide 7, o instinto maternal de Dido é apresentado de forma comedida e bastante racional. De facto, a rainha não demonstra grande emotividade nem o desejo de ter um paruulus Aeneas (A. 4.328-9), seja por razóes sentimentais ou por conveniência monárquica. Tudo o que quer é compensar Ascânio pela perda da mãe. Reconhece, no entanto, a intervenção deste no nascimento da sua paixão por Eneias (107). Ainda que se mostre menos audaciosa do que nas versóes anteriores, Dido distancia-se destas pelo comedimento das suas palavras. O desejo de ser mãe é uma consequência do passado infeliz de Ascânio (108-9), não da vontade de dar continuidade, de materializar os sentimentos 
que a ligam a Eneias. A única finalidade da referência a Ascânio é revelar-se generosa para com o filho do hóspede e mostrar que a sua benevolência contrasta com a ingratidão deste.

Ao contrário da argumentação desenvolvida pela personagem ovidiana, em que Dido acusa Eneias de ser um pai negligente (Ep. 7.153ss.), na Epistula Ascânio não é vítima do pai. As acusaçôes que Dido faz ao Troiano limitam-se, essencialmente, à afirmação de que este náo recompensou convenientemente a generosidade com que ela o recebeu $(9,31-2,38-9,115-16 \ldots)$, violando, assim, os deveres de hospitalidade a que estava obrigado. Acusando Eneias de não recompensar convenientemente a forma como o acolheu, pretende demonstrar que foi vítima de uma transgressão de ordem cívica, fazendo, assim, com que a sua querela ultrapasse o âmbito meramente pessoal ${ }^{8}$.

Ainda assim, Dido não explora o passado de Eneias e as ligaçóes afectivas deste com terceiros para demonstrar que é um criminoso sem escrúpulos. A condenação de Eneias é menos radical do que na Heróide, é mais comedida. Nesta, Dido acusa Eneias da morte de Creúsa, enquanto no texto em análise a referência à esposa troiana de Eneias serve apenas como prova da sensibilidade de Dido e da sua reacção à narraçáo da queda de Tróia (101-5). Dido é menos audaz na interpretação dos factos passados e da responsabilidade de Eneias em acontecimentos como a morte de Creúsa e mesmo a fuga de Tróia e a viagem errante pelos mares que, na obra ovidiana, entende como um castigo dos deuses $(E p$. 7.87-8). Na Epistula, a culpa de Eneias resume-se à forma como recompensa Dido pelo auxílio prestado, transformando-se, assim, num hóspede transgressor.

Antes da referência a Creúsa, surge pela primeira vez um refrão que se repete quatro vezes:

Cui digna rependes, si mihi dura paras? (100-1, 105-6, 111-12 e 116-17) ${ }^{9}$

"A quem retribuis condignamente se para mim reservas actos insensíveis?"

${ }^{8}$ Deste modo, o texto aproxima-se dos exercícios de retórica, nomeadamente das controuersiae, já que, recorrendo à legalidade, tenta convencer um pretenso juíz - no caso, o leitor - de que Dido foi vítima de um delito (Solimano 1988: 23ss.).

${ }^{9} \mathrm{O}$ refrão encabeça as referências a Creúsa (101-5), a Ascânio (106-11), ao acolhimento de Eneias em Cartago (112-16) e as consideraçóes de Dido sobre a ingratidão daquele (117ss.). 
e que acentua a inadequação da atitude de Eneias à prodigalidade de Dido. Solimano 1988: 39 acentua o paralelismo deste refrão com os versos:

Non odit qui uota dolet, nec digna rependit, quisquis laesa gemit.

"Não sente ódio aquele que lamenta os juramentos, nem retribui [condignamente a mulher que chora por ter sido prejudicada.” (126-7)

A associação entre ambos é nítida: Eneias recusa-se a recompensar Dido como esta merece e Dido, por excesso de bondade e de amor, recusa-se também a recompensar o Troiano como este mereceria, ou seja, renuncia ao ódio e à vingança. As motivaçóes destas recusas são, no entanto, divergentes, já que Eneias foge porque é um ser de natureza nociva e impiedosa, enquanto Dido é impelida pela força imensa de uma paixão desinteressada.

Este contraste continua a ser explorado na forma como Dido apresenta a situação precária de Eneias quando chegou a Cartago, como forma de engrandecer a ajuda prestada (112-16). Dido resgatou-o de uma situação extrema, Eneias abandonou-a, rejeitando o compromisso com ela assumido e justificando a partida com a necessidade de cumprir o seu destino, mas a rainha entende o abandono como um atentado à fides e acusa Eneias de falta de boa-fé $(35-6,119,124,130)$, já que os uota do Troiano garantiam a união legítima de ambos. Deste modo, Eneias incorre na acusação de perjúrio, pois violou um compromisso que Dido entende como um casamento legítimo. Acresce ainda o facto de a rainha considerar as razóes apresentadas insuficientes ou inválidas e de Eneias abandonar uma mulher de conduta irrepreensível que por ele nutria um amor profundo. Trata-se, assim, de um repúdio sem justificação.

Dido lamenta o abandono por considerar que em Cartago o Troiano teria tudo o que fosse necessário para ficar e deplora a frieza deste e a traiçáo que a partida significa, reclamando a validade da união de ambos (27-9).

A omissão do episódio ambíguo da união na caverna, durante a caçada, e a ausência de referências a Siqueu e aos pretendentes deixa de lado a questão da legitimidade da relação entre Dido e Eneias, amplificando a importância dos juramentos pelos quais 
se uniram (32-3). O matrimónio é, assim, legítimo, já que Dido considera que Eneias agiu de forma consciente e clara e que a união de ambos foi reconhecida e aceite de forma inequívoca pelas duas partes. Deste modo, Dido considera-se vítima de um engano, já que, ingenuamente, acreditou em Eneias que, depois de ter assumido um compromisso com a rainha, desprezou os juramentos prestados e partiu. Por este motivo, Dido amplifica a caracterização negativa de Eneias, recapitulando as principais acusaçóes e realçando-as na acumulação assindética de adjectivos dos versos 124-5.

A falta de boa-fé por parte do Troiano desencadeia, assim, a fatalidade do destino de Dido, que esta reconhece desde o início da epístola $(8-9,13)$. Eneias é acusado de ingratidão para com a rainha $(6,125,144)$, que o acolheu quando ele estava em dificuldades. Mas, como recompensa pelo auxílio prestado, Eneias foge (138-42). A inadequação entre recompensa e serviços prestados - inclua-se nestes o amor da rainha - acentua a desigualdade da natureza de Dido e de Eneias. Dido ofereceu a Eneias o seu reino, o seu povo, tudo o que tinha (129-30). Em Cartago, Eneias foi rei (140-1). Todavia, trocou este reino por um outro, que o destino lhe impunha (36-7). À imutabilidade deste destino, que terá sido uma das razóes para Eneias partir, contrapóe Dido uma longa digressão em que expóe a alternância e a mudança a que todo o universo está sujeito e que, longe de ser um processo negativo, é um meio de auto-reparação, de compensação intrínseco à natureza. Nesta digressão, repete-se nove vezes o refrão Sua taedia solus / fallere nescit amor. "Só o amor não sabe / mitigar os seus enfados"10. Das fases da lua (43-7) ao esplendor dos campos na primavera (78-81) e à sucessão das sementeiras e das colheitas (63-7), passando pelo silêncio reparador da noite com todos os benefícios que traz às espécies (48-52), o rouxinol que canta de noite as mágoas sofridas (53-7) e os amantes que descansam em harmonia (58-62), sem esquecer o agricultor que recupera as forças necessárias para o dia seguinte (68-72), ou a alternância das marés que regem o mar e que reparam os danos feitos pelas ondas (73-7), todas as coisas estão sujeitas à mudança, à reconstrução, à reparação. Todas as coisas menos o amor, que não tem conserto possível (85-6).

Assim, o amor de Dido afasta-a dos processos de renovação que caracterizam o universo. $\mathrm{O}$ amor transforma Dido num

${ }^{10}$ Versos $42-3,47-8,52-3,57-8,62-3,67-8,72-3,77-8$ e 81-2. 
ser anti-natura. Eneias, porque se rege pela crença de que o seu destino não pode ser mudado, transgride também, por escolha própria, as leis da natureza. Julga-se isento da mutabilidade do universo, recusa-se a mudar o destino, ficando em Cartago. $\mathrm{O}$ discurso define, assim, de forma inovadora, a obstinação de Eneias presente na Eneida e na epístola ovidiana, obras em que é associada à dureza do carvalho $(A .4 .441$ ss., Ep. $7.37-8,52)$ e à desumanidade de outros elementos da natureza (A. 4.365ss., Ep. 7.37ss.).

No seguimento da tradição, Dido, desconfia do poder do destino de Eneias (36) e considera que a partida deste e o consequente rompimento do compromisso de ambos náo encontram justificaçáo cabal no destino, mas foram fruto de uma fraude.

Ainda que Eneias cumpra a missão fundadora que lhe foi imposta pelos deuses, foi em Cartago que conseguiu o poder supremo, ao lado de Dido. Quanto à concretização das promessas divinas, Dido entende que fica aquém da grandiosidade de Cartago. Eneias fez, assim, a escolha errada e Dido reconhece com desilusão e mágoa que, se tivesse ficado com ela, tudo teria sido diferente (143-4).

O vocativo "Eneias, meu ingrato" (144) deixa transparecer de forma manifesta a amargura de quem se sente desprezada e, no entanto, continua a sentir-se ligada a quem a rejeitou. À imagem da Heróide 7, o texto desenvolve, assim, a ambivalência inerente à relação entre Eneias, caracterizado negativamente, e Dido, que se considera vítima. A caracterização de Eneias é menos agressiva do que nas versóes anteriores e, ainda que a personagem se refira ao sentimento de ira que a invade (15 e 144), é a dor que mais transparece do seu discurso. Dido revela a Eneias o desejo abnegado de que este continue a sua vida:

\section{Licet simul improbus exul}

et malus hospes eras et ubique timendus haberis, uiue tamen nostrumque nefas post fata memento. (148-50)

"Ainda que sejas, ao mesmo tempo, um exilado perverso e um hóspede malvado, ainda que em todo o lado te considerem [temível, vive e, depois da minha morte, lembra-te do nosso crime."

Assim, as últimas palavras da rainha retomam a abnegação, a renúncia ao ódio que caracteriza a personagem em Ovídio (Ep. 
7.63-4). No entanto, a concessão que antecede este último desejo define o carácter nocivo de Eneias, que amplifica a generosidade da vítima.

O tom epigráfico que transparece do último verso segue a tradição virgiliana e ovidiana (A.4.653ss., Ep. 7.195-6). Todavia, a referência ao nostrum nefas (150, é ambígua. Solimano 1988: 71 traduz por "il crimine commesso contro di me", entendendo, portanto, que Dido se refere ao abandono de que foi vítima. Em momento algum, contudo, Dido caracteriza a partida de Eneias como um crime, ainda que se considere vítima desse acto de ingratidão. Pode, no entanto, referir-se à união de ambos, a qual, já anteriormente, Dido designou, ainda que ironicamente, como crimen (27). Deste modo, o último pedido seria a manifestação do desejo de continuidade da relaçáo de ambos, na memória de Eneias. Se entendermos o possessivo como um plural majestático, é possível uma terceira interpretação: que Dido se refira ao seu próprio suicídio e deseje que a lembrança da sua morte perdure na mente de Eneias ${ }^{11}$.

Sem a exploração de efeitos visuais como a espada, o sangue ou a pira, a morte de Dido tem um carácter pouco nítido. As feridas que menciona são pouco definidas, assumindo ao longo do texto um aspecto mais metafórico do que real que se mantém nos últimos versos, uma vez que náo se refere a forma como Dido morre (145-7).

A ausência de referências precisas e materiais à espada é interpretada por Solimano 1988: 18 como forma "(...) per evitare la condanna che il suicidio avrebbe potuto attirare." Assim, a classificação da sua morte como nefas seria outra consequência da condenação moral do suicídio, resultado da difusão da doutrina cristá. Obedece ao mesmo propósito a exclusão de temas polémicos como o recurso à magia e a referência dos presságios de índole negativa presentes na Eneida, que poriam em risco a caracterização da personagem como uma mulher injustamente abandonada que, ainda assim, mantém uma conduta moral abnegada e irrepreensível.

Ao renunciar à violência da morte, Dido transforma a sua história num momento de dor, não física mas psicológica. Sem

${ }^{11}$ Dando, deste modo, sequência às últimas palavras que profere na Eneida (A. 4.661-2): Hauriat hunc oculis ignem crudelis ab alto / Dardanus, et nostrae secum ferat omina mortis. "Que o cruel dárdano veja do alto mar com os seus próprios olhos este fogo / e leve consigo o agouro da minha morte.”. 
a expressão do ódio por Eneias e a violência que caracterizam a versão virgiliana, nem a audácia, o esclarecimento e a persuasão que Ovídio imprimiu na sua personagem, a Epistula apresenta-se como a transformação das versôes anteriores num texto menos violento.

Ainda que Desmond 1994: 45-6 identifique o texto da Anthologia Latina como uma imitação directa de Ovídio, a Epistula estabelece algumas relaçóes com a versão virgiliana. Parece-nos, no entanto, que, apesar da relação estreita com as versóes anteriores, o texto explora de forma original traços característicos das personagens, elaborando, assim, uma versão diferente das anteriores, mas construída por oposição ou por paralelismo a estas.

A nível formal, características como o refrão ${ }^{12}$ e a digressão dos versos 43 a 81 afastam o texto das versóes anteriores e conferemlhe um carácter de originalidade, que ultrapassa o simples cotejo com os modelos. Deste modo, o modicus poeta elabora uma forma diferente de ler as auctoritates, adoptando elementos de uma e de outra e fazendo-as convergir num texto que as harmoniza com alguns traços inovadores.

Também a caracterização de Dido e Eneias recebe novos vectores que afastam a Epistula da tradição. Dido define-se como uma mulher que se sente injuriada, mas, ao contrário da versão ovidiana, parece mostrar-se resignada perante o abandono, já que não faz uso de argumentos - verdadeiros ou não - que poderiam ter convencido Eneias a ficar, como a gravidez, nem lança insinuaçóes pouco abonatórias para o carácter do Troiano, como a da responsabilidade na morte de Creúsa. Quando refere os meios que poderia ter utilizado para se vingar de Eneias mas, logo a seguir, os rejeita, ultrapassa a misericórdia da personagem de Ovídio.

Neste processo de transformação, o autor anónimo da Epistula parece aproximar-se parcialmente da versão transmitida pelos historiógrafos e recuperada por alguns autores cristáos, em que Dido nunca se encontra com Eneias e se suicida para se manter fiel à memória do marido. Reduzindo a complexidade moral inerente ao episódio na Eneida e abdicando do violento desejo

${ }^{12}$ Solimano 1988: 39 define o contributo que o uso de refrão dá ao texto: "Questi due ritornelli, esempio di mistione dei generi letterari, conferiscono all' ED [Epistula Didonis ad Aeneam] un tono di lamentosa litania e soppratutto un sapore popolareggiante (...).” 
de vingança que caracteriza a personagem em Virgílio, omitindo o passado da rainha, nomeadamente o casamento com Siqueu e os pretendentes africanos, a Epistula apresenta-nos uma mulher sem outras ligaçóes que não a união com Eneias ${ }^{13}$. O facto de não referir o seu próprio nome e de náo explorar, pelo menos de forma sistemática, os sofrimentos do passado faz com que Dido pareça não ter outra identidade senão a de mulher injustamente rejeitada. $\mathrm{E}$, deste modo, o seu suicídio náo tem como finalidade restituir a reputação perdida, mas esquecer o abandono. Dido define-se como uma mulher casta, sem passado, que morre depois da única uniáo referida no texto e que, em vez de agir contra os revezes da vida, prefere imolar-se na pira. Deste modo, a finalidade do discurso não é tanto persuadir Eneias a ficar mas antes conseguir a compaixão e a compreensão do leitor para si própria.

${ }^{13}$ A omissão de referências ao seu estatuto de rainha e aos Cartagineses afasta também o problema moral da fama e da reputação de Dido, enquanto a ausência das personagens secundárias acentua a importância da relação com Eneias, a única que interessa referir, como se não existisse mais ninguém no mundo e nos afectos de Dido. Solimano 1988: 14 afirma que a omissão de figuras como Ana, Jarbas e Siqueu provoca "una maggiore esasperazione non tanto della solitudine dell'eroina, (...) quanto della fissità e univocità del componimento." 


\section{Anexo \\ Antologia Latina \\ Epístola ESCRITA POR Dido a ENEIAS}

\section{Prefácio}

“Tu, que procuras votos verdadeiros - não importa quem sejas -

[recebe de boa mente os meus

e oxalá respeites os teus. Decide que parte deste poema alegrará o teu tempo livre, leitor benévolo, e, como juiz íntegro,

[assume um espírito justo.

Soa docemente o que o amor canta. Aquele que é capaz de ter bons sentimentos considere digno estimar um humilde poeta."

\section{Poema}

"O amor ofendido devia impedir-me de cumprimentar um ingrato, mas de nada valem as queixas a quem chora, se, ao menos, tivesse tempo para chorar. É que me reclama com mais

[força, homem perverso, o destino da morte. Troiano criminoso, são estes os presentes que dás em troca? Ainda que muitas vezes eu tente acalmar o choro escrevendo um poema triste, 10 a dor é mais forte e as palavras não equivalem à dor de quem sofre. Antes te peço os reinos injuriados que te dei, cercada por um destino infeliz.

Do amor depende a dor, a dor imensa aumenta o amor. Enquanto a pena se esforça por escrever rapidamente queixas iradas, é a própria dor que me refreia a mão e o amor, não me permitindo dizer mais nada, e enreda os caminhos da mente e as palavras. Ah! Quantas vezes se deteve a minha mão e ficou suspensa, tremendo-me o polegar, sem saber o que fazer!

$\mathrm{O}$ torpor embaraça-me a mão e as palavras. Enquanto as letras formam 20 vocábulos severos ou uma palavra menos nítida, a ponta da pena, mal conduzida, desviou-se do percurso correcto, e a minha mente, em dúvida, afastou o pudor. Enquanto escreve as

[palavras e confia os nomes, a chama criminosa regressa, irada, e percorre-me o corpo um calor adormecido e devora-me as entranhas num fogo sinistro. Que ninguém condene uma mulher que se confessa apaixonada. 
Agora o matrimónio era crime? Acreditando, para minha infelicidade, [nos teus votos, dei-te tudo (não se estranhe a minha boa-fé) pensando que, de acordo [com a lei, eras meu marido, o marido a quem também eu pertenci. Jamais os votos pronunciados

[de forma consciente

se cumprirão, se a tua boa-fé não for a que é digna de um marido.

É assim que me recompensas, Troiano? É isto o que o meu sentimento merece? Não te detém a nossa união, nem os juramentos cúmplices do leito? Por que crime perco tudo o que dei por amor?

Ainda que, com a ajuda dos fados, homem cruel, fundes um reino como o meu, não há razão para te vangloriares.

A tua credibilidade perdeu-se por causa da tua fraude, não por causa do

[destino. Mas tu procuravas o reino que te era devido e não podias vencer o destino.

Se te é permitido partir, óptimo! É que, já que foges de onde te acolheram, os teus votos são votos de criminoso. Não há razão para eu me queixar de as tuas palavras e a tua boa-fé serem grosseiras. Todo aquele que

[lamenta as minhas feridas, confirme que não cometi um acto de má vontade. Tudo éconduzido pelo acaso, enquanto a natureza se apodera do destino. Só o amor náo sabe mitigar os seus enfados. Cíntia atinge o máximo do seu brilho, renovado depois de os cornos do seu arco completarem um círculo rubro com a ajuda do irmáo e com a dádiva da luz. $\mathrm{O}$ dia que, de acordo com a lei estabelecida, há-de dar o lugar à irmá, consome o [que lhe é devido. É deste modo

que a natureza mantém o universo, enquanto acolhe a mudança. Só o amor não sabe mitigar os seus enfados. A escuridão da noite rodeia o dia, mergulhado nas sombras lívidas, e desfruta, de acordo com a lei estabelecida, das trevas do céu; as estrelas cintilantes percorrem o seu curso.

As ondas do mar tempestuoso ficam em silêncio, o vento do sul nem

e a brisa não agita o bosque flexível. Só o amor não sabe mitigar os seus enfados. Já, mal se segurando nas asas, fica em silêncio o rouxinol chilreador, pintado, para sua infelicidade, por causa

[da ofensa cometida contra o pudor;

envolvendo no seu abraço as crias queixosas, debaixo do telhado, 55 expia o crime com o amor e, aliviando a tristeza das suas querelas, cala de noite o que lamenta de dia. Só o amor não sabe mitigar os seus enfados. É agora que os amantes são nutridos 
pela união do amor e os filhos completam o compromisso do casamento. A esposa está contente com o marido, o esposo feliz com a sua companheira. 60 $\mathrm{O}$ amor renova os votos e as delícias secretas; o sono harmoniza o leito com a noite. Só o amor não sabe mitigar os seus enfados. A terra transforma-se com as sementes fecundas e, fértil, invoca a brisa da estação do ano que alimenta. O campo reverdece com a relva espessa e a erva ergue os cabelos de aspecto vítreo. O clima não defrauda as espigas no que respeita à promessa de uma produção melhor. Só o amor não sabe mitigar os seus enfados. O lavrador solta o jugo e acolhe a noite por que esperou. $\mathrm{O}$ grato repouso sabe restaurar as forças despendidas e o sono que se introduz no corpo $\quad 70$ não deixa de restituir o vigor e ajuda sempre os esforçados habitantes do campo. Só o amor não sabe mitigar os seus enfados. $\mathrm{O}$ mar refaz a praia depois dos prejuízos que causou pelo seu avanço, ao exercitar-se, tempestuoso, antes de desaparecer. As marés regem o mar com a sua lei e com a sua sucessão repóem o que se perdeu. A natureza tem tempo para os seus deveres. Só o amor não sabe mitigar os seus enfados. Os prados orvalhados na primavera riem com as rosas preciosas e as terras incham de flores. O campo pintalgado esconde-se por debaixo das flores. A natureza 80 [oferece

coroas de folhagem às rosas lascivas. Só o amor não sabe mitigar os seus enfados. Não lhe agrada o silêncio grato da noite nem os dons sagrados do sono ou os presentes da luz, [consome-se e não recebe as tréguas do ano que passa] mas, vencido, apenas o amor nutre as suas feridas entre mil enganos e outros tantos perigos de fraude.

Eu queixo-me dos teus votos. Oxalá, prestes a morrer, eu chorasse em casa e me queixasse em silêncio, oxalá em silêncio eu esgotasse o meu choro, mas é a própria dor que tal me recusa. $\mathrm{O}$ amor mandou-me escrever o que antes o pudor me negou. Pobre de mim! A minha culpa tornou as minhas promessas honestas. Podia espalhar pelo mar os membros do teu corpo e antecipar o último dia da tua vida com a ajuda das ondas ameaçadoras. Podia cortar com a minha própria mão o destino de Julo que está ainda a crescer e despedaçar o seu pequeno

numa morte violenta, trespassar-lhe as entranhas com a espada 95 ou dar os seus membros a comer às feras. Mas afastei o crime do meu peito e ele recuou perante o amor; o amor uniu o coração 
de quem sofreu perigos dignos. Quem quereria ousar tamanho crime contra um hóspede? Quem quereria ter o nome de criminoso?

Nenhum amor se esconde no engano. A quem retribuis condignamente se para mim reservas actos insensíveis? Deplorando o destino da pobre Creúsa e chorando, pronunciei votos infandos contra os deuses e, enquanto falavas, suportei o crime insensível e o quinhão de infortúnios que te couberam em sorte. Fui a primeira a gemer, a manifestar dor e a chorar. A quem retribuis condignamente se para mim reservas actos insensíveis? O doce Ascânio abraçava-se ao meu pescoço; a criança encorajava um amor infeliz. Enquanto a minha boa-fé não queria outra coisa senão devolver-lhe a mãe que perdera, o amor forma um nome verdadeiro com esta garantia falsa e a dor que se manifestou na piedade faz com que eu solte gemidos profundos e lhe dê beijos. A quem

[retribuis condignamente se para mim reservas actos insensíveis? Ainda há pouco eras

[um hóspede da minha costa, nu e exilado, a frota dispersa através das ondas, náufrago... como poderei calar as desgraças que vias ameaçarem-te? Ainda que tivesses tudo,

Cartago deu-te um reino. A quem retribuis condignamente se para mim reservas actos insensíveis? Não há razão para que eu recorra

[à violência

nem para me arrepender de ter dado o que quer que fosse. Nunca

o que poderia perder. Devolve-me antes, pérfido, [considero prejuízo o que o amor deve a si próprio, já que nada merecem as minhas acçóes piedosas. 120 A natureza ensina-nos que existem deuses, a realidade que não devemos temê-los. Porque não posso então acreditar em tal? É que tu permaneces protegido dos enganos mas eu morro por causa da minha devoção a ti.

Perverso, insensível, criminoso, cruel, pérfido, enganador, ingrato relativamente aos meus serviços! Que ameaça fazem as palavras? Aquele que lamenta os juramentos que lhe foram feitos náo odeia, nem [a mulher que chora por ter sido prejudicada retribui condignamente. Consideras [certamente que deixaste para trás o amor por causa das imposições do pudor, a [que recusarei ter concedido tanto: o ceptro, a minha casa, os Tírios, o reino, a cidadela de Cartago e tudo o que, como rainha, me pertencia. É do esposo que eu me queixo, 
homem falacioso, não das leis. Se a paixão não tem valor, penso porém que, pelo facto de seres meu hóspede, és mais infeliz do que criminoso, Troiano, tu que repeles sentimentos dignos enquanto persegues sentimentos indignos. Ainda mal enxuto precipitas-te para o mar e enfrentas, tu que há pouco eras um náufrago, vagas altíssimas. Temes estar em segurança e procuras perigos honrosos. Ao desejares juramentos pouco fiáveis, só preparas para ti próprio, ao partires, perdas consideráveis. Foges, eis que foges, deixando para trás a minha casa e abandonando o miserando palácio de Cartago, que te deu um reino, que te cingiu os cabelos com o diadema sagrado, que preencheu a tua fronte veneranda com a estrela incrustada de pedras preciosas e te confiou o meu amor. Penso que não tens nada mais importante e reinas ainda sem esposa, Eneias, meu ingrato... Na minha dor, a ira recusa-me uma decisão. Mas dá-ma o amor. Oxalá as minhas feridas crescessem com o pranto, mas avanço já, vencida pela determinação de morrer. Não sofrerei, porém, tanto com a morte como por causa do meu irmão. Ainda que sejas, ao mesmo tempo, [um exilado perverso e um hóspede malvado, ainda que em todo o lado te considerem temível, vive e, depois da minha morte, lembra-te do nosso crime." 
AneXos 


\section{ANEXO A}

\section{FAZER REVIVER DIDO}

Ao longo dos séculos, o interesse suscitado por Dido acompanhou a divulgação e o conhecimento da Eneida. ${ }^{1}$ No entanto, a caracterização da personagem foi absorvendo, também, a espaços, a influência de outros autores, nomeadamente de Ovídio, que foi o primeiro a atenuar a complexidade que define a personagem na epopeia virgiliana. Alguns autores, pelo contrário, recuperam o testemunho transmitido pelos historiógrafos, classificando a versão de Virgílio como uma reelaboração fraudulenta da verdadeira história de Dido, que é um exemplo de coragem, castidade e perseverança.

Nos Carmina Burana ${ }^{2}$, a presença de Dido faz-se sentir num grupo de poemas sobre amores náo correspondidos. Recuperando a versão épica e o tom plangente da epístola ovidiana ${ }^{3}$, os poemas 98, 99, 101 e 102 abordam o tema dos amores de Dido e Eneias. $\mathrm{O}$ primeiro apresenta um resumo do episódio da Eneida: o acolhimento de Eneias em Cartago e consequente fascínio de Dido pelo Troiano, as confissóes de Dido a Ana e os conselhos desta à irmá, a caçada e a união na caverna. É de realçar a forma como é caracterizada a união: se Dido utiliza a caçada como pretexto para seduzir Eneias, e ainda que nenhuma das fontes descreva explicitamente o que aconteceu na caverna, neste poema a união é precedida por uma disputa retórica de que Eneias sai vencedor:

\section{Propositionibus}

tribus dux expositis

${ }^{1}$ Este anexo tem como objectivo apresentar uma breve sinopse da pervivência da figura de Dido. Sem pretender ser exaustivo, tem como finalidade percorrer, sem preocupação cronológica, algumas das obras que sobre ela se debruçaram e que ficaram fora da análise a que se procedeu nos capítulos anteriores.

${ }^{2}$ Seguimos a edição de P. Diemer \& D. Diemer (1987), Carmina Burana, Frankfurt am Main, Deutscher Klassiker Verlag.

${ }^{3} \mathrm{O}$ carmen $99 \mathrm{~b}$ é a transcrição dos últimos dois versos da Heróide 7 , que transmitem o epitáfio de Dido: Prebuit Eneas et causam mortis et ensem; / Illa [em vez de Ipsa] sua Dido concidit usa manu. 
sylogizat; motibus

fallit hec oppositis;

et quamuis cogentibus

argumentis utitur,

tamen eis breuibus

tantum horis fallitur. (98.8)

"Com três proposições

o príncipe expóe

a sua tese; com pensamentos

opostos ela tenta enganá-lo;

mas apesar de recorrer

a argumentos para o conter,

em poucas horas

é vencida por eles."

Os fenómenos naturais que, na Eneida, presidem ao momento são aqui substituídos pela bonança que se segue à tempestade, sinal de que a natureza sorri ao amor:

Et sic amborum in coniugio

leta resplenduit etherea regia,

nam ad amoris gaudia

rident, clarescunt omnia. (98.9)

"E durante a união de ambos

o palácio etéreo resplandeceu em júbilo:

é que perante as delícias do amor

riem, brilham todas as coisas."

O carmen 99 começa sob o signo do amor de Páris e Helena, colocando, assim, a união entre Dido e Eneias no âmbito das relaçóes ilegítimas. Por causa do rapto infame de Helena, Tróia é destruída e Eneias é obrigado a fugir. Desembarca na Líbia, onde é recebido por Dido:

Hunc regno suscipit Dido Sydonica

et, plus quam decuit amore saucia,

moras non patitur iungi connubia. (99.3)

"A este acolheu-o no seu reino a Sidónia Dido

e, ferida pelo amor mais do que seria conveniente, não tardou a unir-se a ele pelo casamento." 
Ao comentário de índole moral sobre a paixão de Dido seguem-se algumas consideraçôes sobre o poder do amor e da proximidade deste e da morte (99.4). Estes elementos remetem-nos para a complexidade moral da versão virgiliana, nomeadamente no que diz respeito ao poder destrutivo da paixão da rainha. No entanto, as palavras que a rainha dirige a Eneias, depois de tomar conhecimento de que este decidiu partir, estấo muito mais próximas da ternura e da abnegaçáo da personagem ovidiana:

"Enea domine, quid est quod audio?

Didonem miseram dabis exicio?

quam dura premia pro beneficio!

Dudum exceperam egentem omnium,

deos offenderat nostrum conubium.

quid agam, nescio. mors est consilium. (99.6-7)

"Senhor Eneias, que palavras são as que oiço?

Entregarás a pobre Dido à morte?

Que recompensa tão inadequada ao bem que te fiz!

Acolhi-te, em tempos, privado de tudo,

a nossa união ofendeu os deuses.

Não sei o que fazer. A minha decisão é morrer.”

Realçando a ingratidáo do Troiano, Dido recorda a ajuda que lhe prestou quando estava em apuros e reconhece a intervenção divina e o julgamento dos deuses relativamente à união de ambos. Sem desejo de vingança nem maldiçôes, o amor da rainha impede-a de experimentar sentimentos negativos e a morte é apresentada como a cura para o amor (99.9). A sequência do poema descreve a reacçáo de Eneias à morte da rainha: arranca os cabelos, rasga as vestes e chora. O Troiano reconhece o valor da ajuda prestada por Dido (99.14) e a discrepância da atitude de um e outro, realçada pela antítese morte-vida:

Tu michi fueras uite subsidium, sed ego sum tibi mortis exitium. quam detestabile est hoc commercium! (99.15)

"Tu foste o sustentáculo da minha vida mas eu fui a causa da tua morte.

Que troca abominável!” 
Eneias confessa ainda os sentimentos que omite na Eneida. De facto, amava Dido e, junto dela, conseguira aliviar a dor de ter perdido o pai, a esposa e a pátria. Confirma o seu papel na morte da rainha e justifica a partida com a intervenção dos deuses:

Non semper utile est, diis credere,

nec, quicquid ammonent, uelle perficere;

nam instigauerant me te relinquere. (99.19)

"Nem sempre é proveitoso acreditar nos deuses e querer cumprir tudo o que eles prescrevem.

Eles é que me obrigaram a abandonar-te."

$\mathrm{O}$ agradecimento de Eneias é tardio, mas funciona como uma espécie de absolvição para o Troiano. A culpa, afinal, foi dos deuses que o obrigaram a partir, mas também do amor, sentimento poderoso que arrasta os seres para a desventura e para a morte.

Os poemas 101 e 102 relatam a história do rapto de Helena e da queda de Tróia e o segundo poema insere neste contexto a fuga de Eneias (102.17-21) e o desembarque em Cartago (102.22). A relação com Dido e o abandono são descritos de forma bastante resumida em dois versos: Dido mata-se por amor e Eneias foge (102.23). O encontro com a rainha é apenas mais um episódio na história de Eneias, que culmina com o casamento com Lavínia, união que, ao contrário da relação com Dido, tem a benção dos deuses (102.29).

O carmen 100 é um lamento de Dido, que se penitencia por ter acolhido os Troianos, perseguidos por Juno e por monstros como Celeno, Cila ou os Ciclopes (100.2 $)$. Mas os Troianos respondem inconvenientemente à hospitalidade da rainha, que agora reconhece que sacrificou os seus súbditos a este povo inimigo $\left(100.2^{\mathrm{b}}\right)$. A própria Dido se considera vítima tanto de Eneias como de Jarbas e o seu estatuto de rainha vê-se ameaçado também pelo irmão. É, no entanto, o abandono por parte de Eneias que provoca a sua perda. Dido lamenta os rumores que circulam acerca do seu carácter e que a comparam a Helena:

"Dido se fecit Helenam. regina nostra gremio Troianum fouet aduenam!" (100.4 $4^{\mathrm{b}}$ ) 
"Dido tornou-se Helena.

A nossa rainha no seu coração

Acolheu o estrangeiro troiano."

Perante a consciência da reputação perdida e da injustiça das acusaçóes que lhe são feitas, Dido diz a Ana que é melhor morrer:

nil sorori, nisi mori

soror, restat, unica. $\left(100.5^{a}\right)$

"Nada, a não ser a morte, resta

à tua irmã, ó minha única irmã."

O ciúme que transparece das palavras da rainha, quando conclui que Eneias partiu em busca de Lavínia, e a mágoa de se saber enganada por um deceptor perfidus, um 'enganador mentiroso' que está prestes a soltar amarras e a enfrentar o mar em fúria, consolidam a decisão do suicídio. Dido reconhece a responsabilidade de Eneias na sua morte, que considera um troféu para o Troiano:

hec, Enea,

fer trophea,

causa tanti criminis $\left(100.6^{\mathrm{b}}\right)$

"Leva, Eneias

estes troféus

causa de um crime tấo grande”

No entanto, as últimas palavras da rainha são uma exortação à sua própria alma, para que não esqueça o amor e seja mensageira da dor por ele provocada.

Os Carmina Burana equilibram, assim, as versôes de Virgílio e de Ovídio. Se caracterizam o amor de Dido como um sentimento perigoso, que póe em risco a segurança do seu reino, o certo é que em momento algum se refere o desejo de vingança ou a maldição lançada contra os descendentes de Eneias. Pelo contrário, o fim do carmen 100 é um incitamento à continuidade do amor, que se aproxima mais do poder do amor abnegado da Heróide 7.

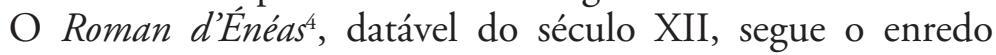

${ }^{4}$ Le Roman d' Énéas (édition critique, traduction, présentation et notes 
da epopeia de Virgílio, acrescentando, no entanto, elementos originais que distanciam a obra do seu modelo. No que diz respeito a Dido, as alteraçóes baseiam-se, essencialmente, na descrição do seu carácter e no empolar da questão moral que subjaz à sua relaçáo com o Troiano. $\mathrm{Na}$ estrutura da obra, Dido opóe-se a Lavínia, a esposa prometida a Eneias que, no Roman d'Énéas, se torna uma personagem com uma individualidade definida e por quem o herói se mostra verdadeiramente apaixonado. As duas mulheres são o oposto uma da outra: se Lavínia é uma jovem inocente e pura, Dido é apresentada como uma viúva sensual e libidinosa, consumida pela paixão que há-de levá-la ao suicídio. O seu papel enquanto rainha recebe grande atenção na obra, que a considera um monarca notável:

Dame Didon dirigeait le pays, ni comte ni marquis ne l'auraient mieux gouverné; jamais royaume ni empire ne fut mieux régi par une femme. (264-7)

Por este motivo, é mais lamentável a ruína a que a paixão a leva. Completamente fascinada pela beleza e pelo valor de Eneias e vítima da intervenção de Cupido que substitui Ascânio, Dido confessa perante Ana o seu amor pelo Troiano, revelando, no entanto, que jurou a Siqueu não se entregar a outro (1387-9). A irmã desempenha o mesmo papel de instigadora que a caracteriza na Eneida. Assume, todavia, um carácter mais condenável, já que, de forma insensível, convence a irmã de que é inútil permanecer fiel a um morto que já não tem poder algum e aconselha-a a reter Eneias em Cartago sob o pretexto de evitar o mar agitado do Inverno e de consertar as naus:

\section{"Ainsi pourrez-vous le retenir, et ensuite faire ce qu'il vous plaira." (1466-7))}

O amor transformou Dido que, possuída, perde a razão (1493) e esquece os seus deveres de monarca. A paixáo faz com que a rainha esqueça todos os limites e, durante a tempestade desencadeada quando Cartagineses e Troianos caçavam, Dido e Eneias unem-se na caverna. A cena da união de ambos, elíptica

d'Aimé Petit), Paris, Librairie Générale Française, 1997. Por uma questão de simplificação, não transcrevemos o original mas apenas a actualização em francês moderno. 
e ambígua em Virgílio, é descrita de forma bastante explícita no Roman d'Énéas:

Les voilà seuls tous deux,

il fait d'elle ce que bon lui semble

sans beaucoup la forcer,

et la reine ne s'y refuse pas,

elle se prête entièrement à son désir:

c'est ce qu'elle désirait depuis longtemps. (1604-9)

Estamos perante dois amantes. A conduta de Dido é, no entanto, repreensível, porque sucumbiu de forma infame e sem opor a mínima resistência à paixão, deitando a perder a sua honra. Avisado por Mercúrio de que deve deixar Cartago, Eneias justifica a sua partida com a vontade dos deuses e afirma:

Si je ne puis vous payer de retour, je ne pourrai pas vous oublier,

je m'en souviendrai toute ma vie, je vous aimerai plus que tout. (1864-7)

Perante estes juramentos, Dido irrompe em acusaçôes de insensibilidade e de ingratidão. Argumentos como a origem selvagem de Eneias (1880ss.) e a fúria do mar (1790-5) ou o lamento de não ter tido um filho dele (1822-7) são retomados por Dido que, à imagem da Eneida e da Heróide, trata Eneias ora pela segunda ora pela terceira pessoa (1890ss.). Dido penitenciase por não ter perseverado no juramento de fidelidade ao defunto marido e reconhece o carácter ilegítimo da união com Eneias (1936, 2076ss.). Decide então morrer e o estrategma a que recorre para enganar Ana é o mesmo da Eneida: finge ter encontrado na magia uma solução para esquecer Eneias. As suas últimas palavras são o reconhecimento do poder desenfreado da paixão:

"je l'ai aimé comme une folle, et cela m'a été fatal." (2132-3)

O elemento mais surpreendente é, no entanto, a ausência da maldição e o facto de, sobre a pira, perdoar Eneias do mal que lhe fez: 
"Il a causé très injustement ma mort

que je lui pardonne à présent:

en signe de parfaite réconciliation,

jembrasse ici ces vêtements;

je vous pardonne, seigneur Enéas." (2148-52)

Assim, ainda que o Roman d'Énéas retome no essencial o enredo da Eneida, sente-se de forma muito nítida a influência de Ovídio, não fosse o século XII a chamada Aetas Ovidiana. $\mathrm{O}$ episódio não se detém na morte da rainha: continua a descrição (mórbida) do corpo a ser consumido pelas chamas e das cerimónias fúnebres. Da grandeza e opulência da vida de Dido, do excesso que caracterizou o seu amor sobram apenas cinzas que são levadas numa pequena urna para o templo onde se edifica um túmulo sumptuoso em que se lê:

le texte dit que: $C i$-git

Didon qui se tua par amour;

jamais il n'y aurait eu de meilleure païenne

si elle n'avait connu un amour soudain,

mais elle aima trop follement,

et sa sagesse ne lui servit à rien."(2224-9)

O epitáfio, recurso de cunho ovidiano, imortaliza não as façanhas heróicas da rainha ou a responsabilidade de Eneias na sua morte, mas a forma desmesurada como Dido sucumbiu perante a força da paixão. Deste modo, condena-se a irracionalidade do amor que leva os seres a cometerem actos reprováveis.

Esta interpretação baseia-se na leitura alegórica da Eneida, que transforma a gesta de Eneias no processo evolutivo do homem. Deste modo, os obstáculos vencidos pelo Troiano simbolizam as fases do crescimento humano. Dido representa o perigo da luxúria e da sexualidade, perigo que Eneias afasta quando abandona a rainha. Dante, no Convivio ${ }^{5}$, sintetiza esta perspectiva:

avendo ricevuto da Dido tanto di piacere (...), e usando con essa tanto di dilettazione, elli si partio, per seguire onesta e laudabile via e fruttuosa, come nel quarto de l'Eneida scritto è! (4.26)

${ }^{5}$ La Letteratura Italiana: Storia e Testi, vol. 5: Dante Alighieri. Opere Minori, (a cura di C. Vasoli e di D. de Robertis) Milano-Napoli, Riccardo Ricciardi Editore, s. d. 
No Inferno ${ }^{6}$, todavia, afastada das questóes de índole teórico-literária do Convivio, Dido recupera características que Virgílio nela imprimiu, como a violaçáo do juramento a Siqueu. Juntamente com Cleópatra, Semíramis, Helena e Páris, entre outros, Dido constitui o grupo daqueles que la ragion sommettono al talento (5.37-8). Acompanham-na na morte as acusaçóes de se ter deixado dominar pelo furor, pela irracionalidade da paixáo e de não ter mantido os votos de fidelidade a Siqueu:

\section{L'altra è colei che s'ancise amorosa, e ruppe fede al cener di Sicheo. (5.61-2)}

A condenação da índole da rainha interpreta de forma clara as entoaçóes mais negativas da Eneida, omitindo a ambiguidade moral da epopeia virgiliana. Assim, Dante dá voz a uma perspectiva redutora do episódio que absolve Eneias e condena Dido por luxúria.

No livro XIV de Genealogia Deorum Gentilium ${ }^{7}$, Boccaccio fundamenta a transformaçáo a que Virgílio procedeu ao elaborar a versão dos amores de Dido e Eneias. Defendendo os poetas da acusação de serem mentirosos, Boccaccio justifica o propósito da ficção virgiliana afirmando que Virgílio, o latinorum poetarum princeps, conhecia perfeitamente a verdadeira história da rainha, exemplo de castidade e perseverança. No entanto, para ilustrar que tipo de tentaçóes assola a existência humana, introduziu Dido na Eneida:

Intendit Virgilius per totum opus ostendere quibus passionibus humana fragilitas infestetur, et quibus uiribus a constanti uiro superentur. Et cum iam non nullas ostendisset, uolens demonstrare quibus ex causis ab appetitu concupiscibili in lasciuiam rapiamur, introducit Dydonem generositate sanguinis claram, etate iuuenem, forma spectabilem, moribus insignem, diuitiis abundantem, castitate famosam, prudentia atque eloquentia circumspectam, ciuitati sue et populo imperantem, et uiduam, quasi ab experientia Veneris concupiscentie aptiorem. (p. 996)

${ }^{6}$ V. Graça Moura, A Divina Comédia de Dante Alighieri, Venda Nova, Bertrand Editora, 1996.

${ }^{7}$ La Letteratura Italiana: Storia e Testi, vol. 9: Giovanni Boccaccio. Opere in Versi, Corbaccio, Trattatello in Laude di Dante, Prose Latine, Epistole, (a cura di Pier Giorgio Ricci) Milano-Napoli, Riccardo Ricciardi Editore, s. d.. 
Pretende Virgílio mostrar em toda a obra as paixóes que atormentam a fraqueza humana e com que forças o homem que se mantém firme as supera. E uma vez que já tinha apresentado algumas, querendo mostrar a que causas somos arrebatados pelo instinto da cobiça para a lascívia, introduz Dido, ilustre pela nobreza do seu sangue, de idade jovem, de beleza notável, de costumes insigne, em riquezas poderosa, conhecida pela sua castidade, e, em prudência e eloquência distinta, reinando sobre a sua cidade e o seu povo, e viúva, como se desta forma fosse mais apta para a concupiscência de Vénus.

A adulteração da verdadeira história de Dido encontra, assim, justificação na intenção didáctica da poesia virgiliana. Deste modo, tanto Virgílio como Dido são absolvidos, respectivamente, das acusaçóes de mentira e de imoralidade.

A forma exaustiva como Boccaccio caracteriza Dido é prova da adesão à personagem. No entanto, o perigo da sexualidade que, de acordo com o autor, Dido simboliza na epopeia virgiliana, é a última característica referida, como se todas as outras confluíssem nesta, tornando a rainha ainda mais perigosa. Relacionando a versão dos historiógrafos com a perspectiva virgiliana mediante a interpretação alegórica da Eneida, Boccaccio legitima a personagem e a epopeia de Virgílio, já que as insere na cultura cristã em que, de outro modo, teriam dificuldade em ser aceites.

Longe da polémica moral e literária, Geoffrey Chaucer recupera o cotejo de Virgílio e Ovídio. Na obra The Legend of Good Women, as referências a Dido demonstram a contaminatio das fontes. No entanto, ainda que se submeta à protecção dos dois autores, é no segundo que Chaucer mais se inspira, já que realça em Dido, não as consideraçóes morais ou éticas, mas essencialmente o seu papel como vítima de Eneias. A par da descrição do poder avassalador do amor, também em outras obras do autor surgem acusaçóes que remetem para a obra de Ovídio, como a identificação da partida de Eneias como uma traição (The Book of the Duchess, 731-4; The House of Fame 1.293-5). Em The Legend of Good Women (1285-9), o narrador justifica o abandono de Dido com o facto de Eneias estar já farto de fingir estar apaixonado pela rainha. Todavia, quando esta o confronta com a suspeita da partida, Eneias alega que o pai lhe apareceu em sonhos e que Mercúrio o incitou a deixar Cartago. Deste modo, a missão divina torna-se um subterfúgio desprezível para enganar Dido. Eneias é, assim, caracterizado 
como um homem trapaceiro que desfruta enquanto lhe apetece do amor e da hospitalidade da rainha, mas que, quando se cansa, foge utilizando de forma ímpia os deuses como justificaçáo para a partida. Esta visão negativa de Eneias, completamente despojado das virtudes que o caracterizam na Eneida, segue um processo iniciado por Ovídio. A própria gravidez de Dido, argumento da personagem ovidiana, é referida em The Legend of Good Women como forma de suscitar a piedade de Eneias. De forma abnegada, Dido lança-se aos pés do Troiano pedindo misericórdia e jurando que será a sua escrava mais humilde, numa atitude que tem como precedente a Heróide 7. É original o papel desempenhado por Ana no evoluir da paixáo de Dido. Ao contrário dos modelos, nesta obra Ana opóe-se às pretensóes da irmã (1182-7), funcionando como uma espécie de voz da consciência, a que, todavia, Dido não dá ouvidos, sucumbindo, consequentemente, à paixão. Relativamente à responsabilidade da uniáo na caverna, o texto é claro: Eneias enganou Dido, fazendo-lhe juras falsas de amor. A culpabilização de Eneias é evidente e desencadeia um longo comentário sobre a perfídia masculina e sobre a credulidade das mulheres (1254-89).

Deste modo, Chaucer dá continuidade à dualidade explorada na epístola ovidiana entre Dido vítima e Eneias culpado.

É às Heróides que Fernão Lopes ${ }^{8}$ se refere quando compara o amor desmesurado de D. Pedro por D. Inês de Castro ao amor descrito nas obras literárias:

E se alguém disser que já houve muitos que tanto e mais que ele amaram, como Adriana e Dido, e outras que não nomeamos, segundo se lê nas suas epistolas, responda-se que não falamos em amores inventados, os quais alguns autores, abastados de eloquência, e floridos em bem ditar, compuseram segundo lhes aprouve, dizendo em nome de tais pessoas frases que nunca nenhuma delas cuidou. Mas falamos naqueles amores que se contam e lêem nas histórias, que têm o fumdamento na verdade.

Dido é, assim, citada como exemplo de um amor grandioso e raro, mas inventado pela eloquência dos poetas, nomeadamente de Ovídio, autor das referidas epistolas.

${ }^{8}$ A. José Saraiva (1997, 4a ed.), As Crónicas de Fernão Lopes, Lisboa, Gradiva. 
O Cancioneiro Geral’ inclui a tradução, da autoria de Joham Rodriguez de Saa, de algumas das Heróides de Ovídio, entre as quais figura a Epistola de Dido aa Eneas. $\mathrm{O}$ argumento, que introduz a epístola propriamente dita, resume o episódio da Eneida:

\author{
chegou Eneas trazido \\ com tormenta e com afronta \\ a Cartago, onde Dido \\ o tomou por seu marido, \\ segundo o poeta conta. \\ E a rainha, ferida \\ de muito grave cuidado, \\ cũ a chaga envelhecida \\ bem dentro d' alma metida \\ d'u amor demasiado, \\ vendo como se queria \\ Eneas dela partir, \\ esta carta lh' escrivia, \\ trabalhando, se podia, \\ sua partida impidir.
}

A exiguidade do excerto provoca a omissão de grande parte do enredo, realçando, no entanto, a ambiguidade da ferida que provocou a morte da rainha. É a dor de um amor excessivo rejeitado que impele Dido a escrever a epístola. Assim, é a definição de Dido como amante desprezada que introduz a traduçáo da epístola ovidiana.

No soneto "Os vestidos Elisa revolvia"10, Camóes imortaliza o momento da morte da rainha, retomando as suas palavras na Eneida (A. 4.651ss.):

Os vestidos Elisa revolvia que lh' Eneias deixara por memória; doces despojos da passada glória, doces, quando seu Fado o consentia.

Entr' eles a fermosa espada via que instrumento foi da triste história

${ }^{9}$ Cancioneiro Geral de Garcia de Resende (fixação do texto e estudo por Aida F. Dias), Lisboa, Imprensa Nacional-Casa da Moeda, 1990.

${ }^{10}$ Luís de Camóes, Rimas (texto estabelecido, revisto e prefaciado por A. da Costa Pimpão), Coimbra, Livraria Almedina, 1994. 
e, como quem de si tinha a vitória,

falando só com ela, assi dezia:

- Fermosa e nova espada, se ficaste

só para executares os enganos

de quem te quis deixar, em minha vida,

sabe que tu comigo t' enganaste;

que, para me tirar de tantos danos,

sobeja-me a tristeza da partida.

Os momentos ditosos que, no passado, viveu ao lado de Eneias contrastam com a dor actual provocada pela separação e pelo abandono. Dirigindo-se à espada do Troiano, Dido afirma que mais dolorosa do que o golpe da espada é a partida de Eneias, que só por si é suficiente para lhe tirar a vida. É, assim, a ferida metafórica do amor pelo herói, que reconhece como uma pessoa de mau carácter e com intençóes enganosas, que lhe causa a morte $^{11}$.

É também sob o signo da morte que Correia Garção compõe a Cantata de Dido ${ }^{12}$. Dominado pelo ambiente lúgubre dos últimos momentos da vida da rainha, o poema recupera elementos da epopeia virgiliana como a loucura de Dido e os presságios que a aterrorizam. $\mathrm{O}$ autor decreve com grande teatralidade a morte da rainha:

Com a convulsa mão súbito arranca

A lâmina fulgente da bainha,

E sobre o duro ferro penetrante

Arroja o tenro, cristalino peito;

E em borbotóes de espuma murmurando,

O quente sangue da ferida salta:

De roxas espadanas rociadas,

Tremem da sala as dóricas colunas.

Três vezes tenta erguer-se,

Três vezes desmaiada, sobre o leito

O corpo revolvendo, ao céu levanta

Os macerados olhos.

11 Também em "ABC em motos", é a morte que domina as referências a Dido: Dido morreu por Eneias, / e vós matais quem vos ama.(...) / Hébis e Dido morreram / Com o vigor da mudança.

${ }^{12}$ Seguimos a reprodução do texto de Correia Garção em Projecto Vercial www.ipn.pt. 
Explorando ao pormenor cada uma das fases do suicídio de Dido (o desembainhar da espada de Eneias, Dido lançando-se sobre a lâmina, o sangue jorrando da ferida...), Correia Garção imprime no poema o dramatismo e a solenidade que caracterizam a personagem em Virgílio. À imagem de Camóes, a Cantata de Dido reelabora também as últimas palavras de Dido na Eneida, quando se dirige às vestes de Eneias:
"Doces despojos,
Tão bem logrados
Dos olhos meus,
Enquanto os fados,
Enquanto Deus
O consentiam,
Da triste Dido
A alma aceitai,
Destes cuidados
Me libertai."

Assim, é para a epopeia virgiliana que esta obra nos remete, elaborando, no entanto, uma composição de tom plangente que explora o pathos inerente à morte da rainha.

Já no século XX, Léopold Sedar Senghor compóe Élégie à Carthage ${ }^{13}$, poema que explora a relação entre Dido e Eneias como a oposição entre dois seres incompatíveis:

Tu pleurais ton dieu blanc, son casque

d'or sur ses lèvres vermeilles

Et merveilleuses, tu pleurais Enée dans

ses senteurs de sapin

Ses yeux d'aurore boréale, la neige

d'avril dans sa barbe diaprée.

Que n'avais-tu fidélement consulté la

Négresse, la Grand-Prêtresse de Tanit

couleur de nuit? (...)

Elle t'aurait dit le chiffre d'Iarbas, fils de

Garamantis.

Mais tu dédaignais sa sombre splendeur,

à l'indomptable.

Que n'avais-tu donc percé l'entente des

13 Seguimos a reprodução do texto de Senghor em A. Bescaouch. La Légende de Carthage, s. 1., Gallimard (1993): 162-5. 
dieux aryens, de leurs fidèles

Si infidèles comme ton Enée. Pourtant

ce soir

Sur toi je pleure, sur toi Didon, ma trop grande désolation. (Élégie à Carthage II)

O triângulo formado por Dido, Eneias e Jarbas baseia-se em questóes raciais e a condenação de Dido não é de índole moral, mas assenta na injustiça da escolha que a rainha fez, relacionandose de forma demasiado intensa com Eneias, representante de uma outra raça. Dido oscila, assim, entre dois mundos: entre o mundo de Eneias e dos seus deuses e o seu próprio mundo, que é também o mundo de Jarbas, isto é, o mundo da Negritude. O amor por Eneias é apresentado como um amor que só provoca sofrimento e, por esse motivo, é condenável.

De um modo geral, é a influência de Virgílio que mais se faz sentir na literatura, acompanhada, muitas vezes, por ecos da obra de Ovídio ${ }^{14}$. Ainda assim, a versão da casta Dido aflora, a espaços. Para relevar o encanto suscitado pela personagem, embrenhada na complexidade moral da Eneida, e o fascínio pelas obras de Virgílio e Ovídio, é frequentemente evocada a tradição historiográfica. Opondo aos autores referidos (principalmente a Virgílio) o testemunho de Justino, restitui-se à personagem a irrepreensibilidade que a define na historiografia. Este processo invoca também o papel polémico da poesia e a forma como esta se relaciona com a verdade.

Nos Trionf $i^{15}$, Petrarca desmente que a causa da morte de Dido tenha sido a paixão e o abandono de Eneias. Garante que esta é a perspectiva mais popular da vida da rainha, perspectiva que o vulgo prefere porque apresenta pormenores mais lúbricos:

\section{(...) Dido \\ ch' amor pio del suo sposo a morte spinse, non quel d' Enea com' è publico grido (...)}

${ }^{14}$ Nas Viagens na Minha Terra, Almeida Garrett refere-se a Dido como símbolo dos grandes modelos literários do passado, que foram destronados pelo Romantismo: Dido chorando por Eneias náo tinha sido reduzida a donzela choramingas de Alfama carpindo pelo seu Manel que vai para a Índia... (cap. VI). Nota-se o mesmo processo de popularização no capítulo XI, quando o narrador, antes de citar o verso 4.23 da Eneida - adgnosco ueteris uestigia flammae - se refere à irmã de Dido pelo diminutivo Anica. (Almeida Garrett, Viagens na Minha Terra, Porto, Porto-Editora, $1988^{2}$ ).

${ }^{15}$ Francesco Petrarca. Trionfi (introduzione e note di G. Bezzola), Milano, Rizzoli Editore, 1984. 


\section{(...)}

quella che per lo suo diletto e fido sposo, non per Enea, volse ire al fine (taccia 'l vulgo ignorante); io dico Dido cui studio d' onestate a morte spinse, non vano amor com' è 'l publico grido.

(Trionfo della Pudicizia, 11-12, 155-9)

Dido suicidou-se para se manter fiel ao seu marido Siqueu. À imagem de Tertuliano, Petrarca evoca o nome da rainha entre outros exemplos de mulheres virtuosas, como Lucrécia ou Virgínia, considerando a versão da Eneida uma desvirtualização do carácter impoluto de Dido, que não cedeu a uma nova paixão, mantendo-se fiel à memória do marido e ao amor que a este a unia.

Também Bocage ${ }^{16}$, no soneto "À constância de Dido", classifica a versão virgiliana como uma mentira, cuja divulgação teve como consequência a difamação da honra da rainha. Estes autores recuperam a denúncia do poder da poesia apresentada pelo epigrama 151 da Antologia de Planudes e pelo epigrama 45 dos Epigrammata Bobiensia.

No fim do século XX, a versão da casta Dido foi novamente revisitada. O romance de Fawzy Mellah, Elissa, La Reine Vagabonde $^{17}$, faz reviver a versão menos conhecida do mito, a versão dos historiógrafos. A obra assume a forma epistolar como suporte para a expressão dos sentimentos da rainha. Estamos, porém, longe de Ovídio e da Epistula Didonis ad Aeneam, já que o destinatário é Pigmaliáo. Afastada de Eneias e da história de Roma, Elissa - não Dido - assume por inteiro o seu papel de fundadora de Cartago. Pouco antes de se imolar na pira, Elissa descreve retrospectivamente a sua vida desde a fuga da Fenícia. É devido ao convívio com outros povos que, frequentemente, olham os refugiados que vêm do mar com desconfiança, que o grupo se transforma numa verdadeira comunidade e aceita Elissa como rainha. Mas a consolidação desta sociedade faz-se de forma lenta e dolorosa até à fundação de Qart Hadasht.

É para garantir a sobrevivência da sua cidade que Elissa aceita casar com Hiarbas. Mas antes de consumar a uniáo, imolar-se-á na pira:

${ }^{16}$ Obras de Bocage, Porto, Lello \& Irmão Editores, 1968, 154.

${ }^{17}$ Fawzy Mellah, Elissa, La Reine Vagabonde, Paris, Le Seuil, 1988. 
Le mariage sera conclu au lever du jour; l'union, cependant, ne sera pas consommée. Je m'immolerai avant que cet homme ne me touche. Devenu mon époux, il ne pourra contester l'existence de mon peuple sur ses terres. Ainsi ma communauté se maintiendra-t-elle ici dans la dignité et la sûreté qu'autorise l'alliance conjugale. (p. 22)

A morte é também uma forma de se manter fiel ao marido, a um marido que foi mais um pai ou um amigo protector (p. 23). O casamento com Aquerbas foi, antes de mais, uma forma de este a proteger contra Pigmalião e, por essa razão, um casamento sem filhos:

Mon oncle Acherbas, vous le savez, ne désirait pas d'enfant de notre union; il ne mavait épousée que pour mieux me protéger contre vous. Je rêvais pourtant de grossesses multiples et fécondes. (p. 80)

No entanto, o desejo de ser mãe cedo se desvanece no gosto pela errância, pelo nomadismo. A fixação em Cartago foi o fim da sua viagem e, por essa mesma razão, será o fim da sua vida. A obra de Fawzy Mellah apresenta a personagem como uma mulher que tem como papel principal a liderança do seu povo até ao exílio. Terminada a fuga da Fenícia, os cidadáos de Cartago pretendem que ela case, para consolidarem as relaçóes com os povos vizinhos. Mas Elissa prefere a morte, porque o seu desejo de evasão não permite que ela crie raízes. Baseando-se no relato de Justino, Elissa, La Reine Vagabonde acrescenta à personagem o gosto pela viagem, pelo efémero, diminuindo assim o seu papel como líder, considerado por Elissa uma contingência do seu destino.

Também nas artes plásticas se fez sentir a influência da história de $\mathrm{Dido}^{18}$. Os principais momentos da vida da rainha inspiraram um grande número de obras.

Guérin $^{19}$ criou uma Dido ajoelhada aos pés de Eneias, enquanto este descreve a queda de Tróia. Da atitude da rainha, contemplando, embevecida, o herói, enquanto abraça o pequeno

${ }^{18}$ Deixamos de lado representaçóes pictóricas que mereceriam referência, como as iluminuras dos manuscritos da Eneida e de outras obras que se debruçam sobre a personagem ou as ilustraçóes das diversas ediçóes e traduçóes da epopeia virgiliana. Para uma listagem das representaçóes do episódio na pintura cf. Hano 1990.

19 "Énée racontant à Didon les malheurs de la ville de Troie", Paris, Louvre, datado de 1819. Réplica do Musée des Beaux-Arts de Bordéus em Martin 1990. 
Ascânio, transparece o amor que se gera no seu coração. O olhar de Eneias, todavia, recai sobre uma personagem que é identificável com Acates, como se neste desencontro se delineasse a impossibilidade de uma relação com Dido e a indiferença de Eneias perante a rainha.

A separação inspirou "Dido Resolved" de David Ligare que esboçou uma figura sentada, numa atitude estranhamente calma, que parece reflectir a resignação perante a partida de Eneias e a tranquilidade de um espírito que vai ser apaziguado pela morte.

O quadro de Rubens "La Mort de Didon", no Museu do Louvre, mostra grande afinidade com as versóes que apresentam de forma trágica a morte da rainha. A expressáo do rosto de Dido é de grande dor e perturbação e reevoca a descrição patética da personagem virgiliana. Empunhando a espada de Eneias, Dido prepara-se para desferir o golpe fatal ${ }^{20}$.

Das apropriaçóes musicais de que Dido foi alvo, salientamos a ópera Dido and Aeneas de Henry Purcell (libretto de Nahum Tate) de $1690^{21}$. Nesta obra, Dido é a hiperbolização da personagem virgiliana, é como que uma força da natureza por oposição ao vacilante Eneias. É basicamente este o conflito da obra de Purcell: Eneias, enganado pelo estratagema de umas malvadas feiticeiras, resolve abandonar Dido; confrontado com a rainha, resolve ficar, mas a intenção, mesmo passageira, de a abandonar, Dido não a perdoa. A rainha de Cartago exige um amor incondicional e sem hesitaçóes, mas Eneias mostra-se incapaz de um tal sentimento. É este fracasso que enaltece Dido e rebaixa Eneias, não só em Dido and Aeneas, mas em grande parte da tradição literária que aborda o mito.

Alguns contornos tradicionais do mito são alterados nesta ópera. Assim, a confidente de Dido é Belinda que, ao jeito de Ana na Eneida, compreende os sentimentos de Eneias e incentiva a paixão de Dido. As feiticeiras, que assumem o papel de elementos desencadeadores do mal são uma inovação na obra, e os deuses e a problemática do destino, cruciais em Virgílio, não ultrapassam nesta obra o estatuto de meras convençóes literárias, sem qualquer força dramática ou actuante. Apenas Mercúrio e os Cupidos têm lugar no enredo, desempenhando papéis meramente decorativos:

${ }^{20} \mathrm{O}$ seu estatuto de monarca está representado na coroa, o único ornamento que usa.

${ }^{21}$ Purcell, Dido and Aeneas (Opera in Three Acts), The Scholars Baroque Ensemble, 1994. 
Mercúrio surge apenas indirectamente, pois é o espírito da feiticeira que se faz passar pelo deus; os Cupidos, como referido adiante, surgem apenas no fim, depois da morte da rainha.

Nesta ópera, Dido é a vítima, tanto da maldade das feiticerias e da insensatez de Belinda, quanto do amor hesitante e fraco de Eneias e da sua própria obstinação.

A segunda cena do Acto III apresenta o desenlace, a morte de Dido, depois do debate com Eneias e da partida deste. Os altos e baixos da cena definem o carácter de Dido: a força irrevogável da intolerância de um amor que hesita por um momento e a decisão, tão irrevogável quanto a intolerância, de que não pode mais viver.

A personagem Dido em Purcell enfileira o estatuto da mulher abandonada, impresso no mito desde Virgílio, mas não é o abandono de que é vítima que a leva à morte. A causa da sua morte é a desconfiança da força do amor de Eneias e a náoaceitação de um amor vacilante:

For 'tis enough, what'er you now decree,

That you had once a thought of leaving me.(Acto III)

Nos últimos momentos, a aproximação da morte surge como a chegada de um hóspede bem-vindo - Death is now a welcome guest. - e a cólera e a dor de um amor não correspondido (pelo menos, não inteiramente correspondido) são esquecidas.

É a Belinda e aos seus súbditos que se destinam as suas últimas palavras. A preocupação por aqueles que ficam, pela memória que guardarão de si:

When I am laid in earth

May my wrongs create

No trouble in thy breast.

Remember me, but ab! forget my fate. (Acto III)

No fim, Cupidos sobrevoam o seu túmulo, como dei ex machina, espalhando rosas, e o Coro canta:

With drooping wings ye Cupids come,

And scatter roses on her tomb,

Soft and gentle as her heart.

Keep there your watch, and never part. (Acto III) 
Se analisarmos esta personagem à luz dos vectores que orientaram a nossa pesquisa, nomeadamente em Virgílio, cumpre concluir que a redução da multiplicidade de significados e apropriaçóes inatas à personagem virgiliana contribuem em Purcell para uma unidade trágica mais nítida e actuante. A característica mais importante desta personagem é a sua personalidade tenaz e obstinada. Todos os outros elementos se desvanecem, incluindo a problemática moral e política que o episódio desenvolve na Eneida. O drama do enredo assenta no confronto entre duas personalidades diferentes, em condiçóes que se tornam adversas pela acção não de elementos divinos, como na Eneida, mas sobrenaturais e malignos.

A pluralidade de perspectivas englobada nas versóes que se debruçam sobre Dido perpetua a diversidade que a sua génese revelou, não sem, no entanto, incorporar elementos característicos do contexto cultural em que foram elaboradas. Exemplo de castidade e de luxúria, amante devotada e inocente ou viúva devassa, vítima de uma traição ou do destino, a multiplicidade que caracteriza Dido permite abordá-la de perspectivas divergentes, sem a desapropriar da riqueza de sentidos que Virgílio nela imprimiu. 


\title{
Anexo B
}

\author{
Dido em JacQueline Kelen: \\ A BELEZA DO AMOR E O AMOR DA BELEZA \\ (UM EXEMPLO DE ACTUALIZAÇÃO)
}

Jornalista de France-Culture, Jacqueline Kelen tem publicado ao longo dos anos uma obra vasta que aborda essencialmente o papel das mulheres e do amor na mitologia ocidental. Les Femmes de la Bible (1985), Les Nuits de Schéhérazade (1986), Propositions d'amour (1995), Les Femmes Éternelles (1997), Aimer d'amitié (1999) e La Déesse Nue. Contes de la Belle au Bain (2000) são alguns dos títulos que constituem a produçáo da autora.

Les Reines Noires ${ }^{1}$, obra publicada em 1987, evoca três personagens femininas da Antiguidade, todas de origem oriental. A obra está dividida em três secçôes que se debruçam sobre Dido, Salomé e sobre a Rainha de Sabá e que têm como título, respectivamente, Didon: L'Archéologie des Adieux, Salomé: La Folie-Salomé e La Reine de Saba: L'Enfant d'orviétan.

A introdução, com o título L'Orient Féminin, explica a associação entre as três personagens. Aí, a Autora expóe as causas que conferem a cada uma destas personagens o encanto que as caracteriza:

Elles vivent dans un pays où la lumière est reine, elles savent que l'amour brûle toutes limites et elles semblent toujours quoique très présentes être ailleurs - happées par le songe, l'invisible, l'absolu. (p. 5)

As três mulheres partilham a veneração do amor como forma de existência superior, afastada das leis, da noção de dever e de destino. $\mathrm{O}$ amor é, assim, um sentimento transcendente, alheado das contingências do mundo e isento de limites. É um estado absoluto a que só alguns podem ascender.

Dido partilha também este desejo de atingir um sentimento de natureza sublime e, por esta razão, o motivo central de Didon: L'

${ }^{1}$ Les Reines Noires: Didon, Salomé, la Reine de Saba, Paris, Albin Michel, 1987. 
Archéologie des Adieux é a emocionalidade da rainha. O seu papel de heroína fundadora e o seu estatuto de rainha são apresentados de forma ténue e resumida (p. 34). Dido relembra com orgulho o seu passado heróico, que, mediante a mudança do seu próprio nome, se funde com a sua natureza feminina:

On m’a nommée aussi reine errante, car j'avais dû quitter Tyr pour Carthage et changer Élissa pour Didon. La femme est nomade: elle aime habiter des noms, des royaumes différents, des robes nouvelles; elle paraît changeante comme la lune, qui pourtant ne disparaît pas et revient immanquablement. La femme est nomade mais constante: insaisissable peut-être, mais impossible à perdre. (p. 44)

A importância que a oposição dos valores e sentimentos de Dido e Eneias assume em Les Reines Noires retoma o tom da Heróide 7. No entanto, na obra de Kelen, a personagem mostrase mais linear do que em Ovídio e em Virgílio, que exploram de forma mais sistemática o desequilíbrio emocional da rainha. Em Les Reines Noires, a loucura é substituída por uma capacidade de análise introspectiva poderosa, que permite a exposição lógica dos sentimentos e desejos mais profundos de Dido.

O número de personagens é reduzido. À imagem da epístola de Ovídio, os pensamentos que a rainha dirige a Eneias dominam o texto. A presença de Siqueu é acessória, como a própria Dido reconhece:

Mon époux royal Sichée avait depuis longtemps quitté cette terre de méprises habitée de fantoches, depuis si longtemps que je me demande si un jour, autrefois, sur la terre sidonienne j'ai vécu avec lui, partageant son royaume et sa couche. (p. 48)

Ana desempenha também um papel secundário, retomando a sua função de confidente, mas de forma discreta, num único capítulo, em que Dido disserta sobre os seus sonhos e evoca a voz da irmá: "Tu rêves, tu rêves encore...", murmure Anna, la tendre soeur. (p. 40).

Assim, circunscrevendo as relaçôes interpessoais praticamente ao encontro entre Dido e Eneias, a obra explora a dualidade e a oposição entre ambos e o conflito emocional que daí advém. É, no entanto, a perspectiva da rainha que domina o texto, já que são as reflexóes que dirige ao Troiano que ocupam a maior parte da narrativa. 
O primeiro capítulo informa o leitor de que a morte da rainha está iminente. Assim, como na Heróide 7, é sob o signo do suicídio de Dido que se inicia o discurso da rainha, identificado como um canto. $\mathrm{O}$ narrador omnisciente, que se manifesta ocasionalmente, afirma no texto que antecede o primeiro capítulo:

Didon chante, s'avançant vers la mort, elle chante de sa voix grave où le tragique se mêle à la sensualité. C'est un long cri jeté depuis Carthage, depuis toujours, à la surface des eaux, un cri qui dépasse le pâle Énée pour défier les dieux, un cri qui traverse les mers et la mort pour défendre l'amour, pour le sauver peut-être. (p. 15)

Assim, amor e morte fundem-se na génese da obra, revelando uma cumplicidade óbvia com Ovídio. No entanto, a força da personagem ultrapassa os limites da natureza humana que a caracterizam na epístola ovidiana, aproximando-se do excesso da versão épica.

Je suis reine du présent, afirma Dido, ao pedir a Eneias que não prepare para ela nem uma oração fúnebre nem um epitáfio ( $p$. 19). Para Dido, só o presente existe ${ }^{2}$. Eneias, pelo contrário, vive perdido entre o passado e o futuro, enredado nas suas próprias memórias e utilizando o amanhã como um pretexto para não enfrentar o presente. É por esse motivo que tem necessidade de distrair Dido com o relato da guerra de Tróia, porque as palavras que descrevem o passado dão a quem narra a ilusão de ter uma existência, uma individualidade que não existe verdadeiramente, que nada mais é do que fumo ou vapor. A narração do passado é também uma forma de entreter a mulher, de desviar a sua atenção, evitando, deste modo, o confronto com o amor. Esta evasão do presente, que equivale a uma fuga da mulher, é, de acordo com a rainha, uma fraqueza típica do homem:

Je crois (...) que les hommes sont incapables d'aimer la Femme car ils ont peur d'épouser le présent, car ils redoutent de rencontrer linconnu. (p. 54)

${ }^{2}$ A ausência de preocupação pelo futuro torna irrelevante o desejo de ser mãe. O carácter absoluto de Dido, além de repelir Eneias, exclui o instinto maternal que a caracteriza nas versões de Virgílio e de Ovídio: $M o i$ je n'avais souci de prolongement, ni de vivre avec vous au fil des ans ni $d$ 'avoir de vous un enfant. Je voulais seulement que vous me reconnaissiez, l'espace d'un instant, comme votre femme, votre présent, votre profondeur. (p. 20). 
Este desencontro é causado pela diferença insuperável que caracteriza os sexos. Dido é o absoluto, vive em plenitude. Eneias, pelo contrário, vive condicionado pela preocupaçáo de lançar amarras, de ter referências, de reger a sua vida por leis e, perante um ser misterioso como a mulher, sente medo e opta pela fuga em vez do confronto. É esta a dissonância inexorável que os separa.

A relação entre Dido e Eneias é, assim, apresentada como a oposição primordial entre homem e mulher, seres de natureza diversa, dificilmente conciliável (p. 19). Eneias teve medo da força do amor de Dido, como Ulisses receou o amor de Circe, Calipso e Nausícaa. Pela mesma razão, Teseu abandonou Ariadne e Jasão abandonou Medeia. Fugiram porque o amor de uma mulher tem uma dimensão cósmica que ultrapassa a existência humana e que, por esse motivo, assusta o homem, que, por medo, é incapaz de ser l'élu, l'unique, l'être irremplaçable (p. 18). Mesmo os heróis mais destemidos, os que enfrentaram batalhas e monstros invencíveis, recuaram perante o mistério e o poder do coração feminino.

O relacionamento entre os sexos é, assim, sempre incompleto e precário, está eternamente condenadoà imperfeição eao abandono. O encontro entre um homem e uma mulher é descrito como o encontro do Sol com a Lua: durante a noite, o Sol ilumina a Lua com a sua luz, mas, na manhã posterior, afastam-se, e, quando se voltarem a encontrar, a Lua será a mesma, mas, ao mesmo tempo, será outra, porque terá outro tamanho. No entanto, todas as noites a Lua espera o Sol, pelo qual morrerá na manhã seguinte (pp. 44-5). Este processo cíclico de encontro e separação descreve também a relação amorosa de Dido e Eneias: Dido espera pelo Troiano, que sabe ser o homem por quem morrerá, quando, no dia a seguir, ele se afastar dela, como o Sol da Lua:

Je suis femme de la nuit et du mystère, reine noire qui à la fois se lamente sur l'amant perdu et, se sentant trahie, affûte la faucille de la vengeance et réclame le sang du coupable. C'est un grand chant de Création où vous et moi passons comme des allégories pour incarner l'impossible durée et pour refaire, avant bien d'autres amants, après tant d'autres astres, l'union de l'amour et de l'adieu. (p. 45)

Para completar este ciclo, que é o ciclo da sua própria vida, Dido convocou mentalmente Eneias:

Si vous êtes déjà présent sur les murs de ma chambre, c'est parce que je vous ai suscité, convoqué ici au croisement de nos histoires. Je vous 
ai appelé comme un destin, comme un bourreau, comme ma mort même. (p. 48)

A rainha escolheu Eneias não por ele ser especial, mas por ele ser exactamente como todos os outros: (...) un homme qui ne fut ni plus grand ni plus admirable que tous les précédents (...) (p. 48). $\mathrm{O}$ encontro de ambos não é, assim, obra do acaso. Pelo contrário, faz parte da ordem inelutável do destino. Estava previsto que Eneias desembarcasse em Cartago. A fuga do Troiano não tem como objectivo a fundação de Roma. Tem como fim último libertar Dido da vida, dar descanso ao seu coração, fatigado por amar em excesso (p. 49). Dido vive apenas para o amor, pelo amor. Nada mais lhe interessa. Existe apenas para encontrar o objecto do seu amor, um homem que o mereça. Esta procura é, todavia, extenuante, uma vez que está, ab initio, condenada ao fracasso. Nenhum homem será capaz de enfrentar este desafio.

Relativamente a Eneias, o absoluto assusta-o, porque, ao contrário de Dido, é um ser feito de aparências. É por esse motivo que dá tanta importância às palavras. Porque é nelas que ele existe. São as palavras que dão consistência a um ser sem substância, que lhe dão a ilusão de ser forte, de ser grandioso. No fundo, Eneias, como outros heróis, nada mais é do que uma carapaça oca, feita de palavras mentirosas (p. 28). Mas o efeito destas palavras na mulher, que as ouve atentamente, é assustador, porque inflamam nela a paixão, porque a fazem admirar um ser que não existe, ou melhor, que só existe no discurso, homme de mots, non de chair (p. 27), que se auto-inventa para se proteger do medo que sente perante o amor e perante a mulher ${ }^{3}$. Para escapar com honra a este desafio aterrador, Eneias justifica a partida utilizando o futuro como pretexto. $\mathrm{O}$ entendimento que Dido tem do destino do Troiano retoma, no entanto, a desvalorização patente no texto ovidiano:

Vous avez pris prétexte de votre destin de guerrier et de héros pour échapper à la passion d'une femme, à un corps indicible, amoureux. (...) Vous avez préféré rester le jouet du hasard et des dieux, vous ranger sous la loi du devoir inéluctable et si commun, tellement moins exigeant que l'acceptation de l'amour. (pp. 17-18)

3 Inspiradas pelos deuses, as palavras de Eneias são palavras au pelage luisant, ao contrário das palavras de Dido, manchadas pelo sangue: Ses mots à lui étaient lisses, ils coulaient facilement, je les crus chanson. Les miens étaient pleins de sang; ils firent fuir le héros délicat, qui risquait d'y tacher sa tunique et d'y noyer son corps (p. 25). 
A missão é uma desculpa para escapar, aterrorizado, da relação amorosa. A viagem de Eneias náo é uma procura, é uma fuga constante (p. 43). Por esta razão, Eneias só será recordado porque o seu caminho se cruzou com o da rainha, porque, por ele, Dido pôs fim à sua vida, ligando para sempre o seu nome ao do Troiano. Será a morte de Dido, e não a missão divina, a acção que concederá a Eneias a eternidade:

C'est ma mort, Énée, qui aux yeux de la postérité vous donnera de l'importance et d'abord à mes propres yeux. Ma mort est moins signe de désespoir qu'ultime recours pour vous racheter, vous exhausser, homme gris, anonyme, sans qualités ni identité, pour vous donner vie et visage. (p. 17)

O Troiano viverá não por causa do discurso de herói nem da fuga ao amor, mas porque uma mulher morreu depois de se ter encontrado com ele. E esta será a essência de Eneias: aquele por quem uma rainha se apaixonou e se suicidou, para lhe conferir uma dignidade e uma importância que ele não tem. Assim, Eneias tornar-se-á sublime aos olhos dos vindouros e, essencialmente, aos olhos da própria Dido.

As divergências entre os dois impossibilitam a existência de uma união verdadeira, porque Eneias chegou a Cartago escondido por detrás de uma máscara, enganando Dido com a beleza que Vénus derramou sobre ele e com as palavras falsas que os deuses lhe inspiraram (p. 25). É o reconhecimento da natureza enganadora de Eneias que faz com que Dido decida terminar a sua vida. Não são nem a partida nem o abandono que provocam a morte da rainha. É a falácia que caracterizou a chegada de Eneias a Cartago e todos os acontecimentos posteriores que fazem com que Dido prefira morrer, numa última tentativa de conferir alguma dignidade à relação entre ambos. Eneias é apenas um nome, uma máscara que não esconde nada, um ser sem essência, sem existência, porque foge do amor. É o reconhecimento deste vazio na pessoa amada que é a causa da morte da rainha:

Énée m'a tué davantage par cette tromperie initiale, par cette ruse sacrilège, que par sa fuite. S'il est parjure, perfide, c'est pour avoir montré un visage emprunté, pour avoir prononcé des paroles fausses, c'est pour s'être introduit ici sous une armure trompeuse. (...) Il m'a tuée parce qu'il n'était qu'un masque. (...) Ma mort vient non d'une 
rencontre, suivie de trabison et d'abandon: elle vient d'une absence de rencontre. Rien n'a eu lieu. (pp. 25-6)

A lucidez com que analisa a união de ambos afasta Dido da versão épica, superando, ao mesmo tempo, a perspectiva da personagem ovidiana, que demonstrara já alguma perspicácia na interpretação dos acontecimentos. Também em Les Reines Noires a rainha se sente traída, mas náo por causa da partida de Eneias. Considera-se enganada pelas palavras do Troiano, que sabe serem falsas. Entende que foi enganada desde o início, desde a chegada deste a Cartago. Compreende que foi vítima de uma emboscada. Mostra-se, assim, longe da personagem épica, cega, primeiro de paixão e depois de ódio. Simultaneamente, afasta-se de forma visível da rainha abnegada e intencionalmente queixosa de Ovídio. Na obra de Kelen, Dido analisa de forma mais lúcida as circunstâncias, porque, ainda que viva no e pelo presente, conhece, de forma indirecta e velada, o passado e o futuro, já que a decoração do seu quarto reproduz não só acontecimentos da guerra de Tróia (à imagem do templo de Juno na Eneida) mas também acontecimentos que teráo lugar em breve.

Dido reconhece o orgulho ingénuo de Eneias quando, nos aposentos da rainha, aquele vê representadas cenas da guerra de Tróia e rejubila por julgar que o seu passado de herói foi já divulgado pela fama (p. 46ss.). Nem sequer considera a hipótese de que, se a sua imagem estava em Cartago antes de ele chegar, é porque os deuses utilizaram as mãos de Dido para representar, antecipadamente, o destino, porque permitiram que desse forma aos seus desejos e sonhos. Por este motivo, Dido conhecia já Eneias, porque ele era o homem que ela esperava para cumprir o seu fado:

Me croiras-tu, Énée, homme pieux: je te savais avant de te rencontrer. C'est moi qui t'ai créé, rêvé, tissé et modelé. Je te connaissais puisque je t'avais fait de la tendresse de mes mains, du tissu de mes songes. Je savais que tu viendrais, je n'avais plus qu'à attendre... (p. 47)

Assim, ao contrário das versões anteriores, na obra de Kelen, é o destino de Dido que é importante, que controla a narrativa. A pretensa missão de Eneias é irrelevante, porque é apenas uma fuga.

As imagens no quarto de Dido representam também a relação entre os dois: uma tempestade, uma gruta, e, debaixo da folhagem, 
dois corpos abraçados - dos quais um era o de um caçador - uma frota afastando-se da praia e, em primeiro plano, uma pira e um gládio preparados para um sacrifício.

Recuperando um dos motivos mais importantes do episódio na Eneida, também em Les Reines Noires a união é apresentada como uma acção desigual, em que uma das partes persegue a outra. Dido conhece o carácter unilateral da relação, sem, no entanto, identificar ainda qual dos dois é o caçador e qual é a vítima. Mais adiante, todavia, reconhecerá a reciprocidade desta perseguição. Assim, na actividade de carácter venatório que caracteriza a convivência de ambos, os papéis estão definidos. Cada um deles tentou manipular, aprisionar o outro (p. 62). Quando Eneias se apercebe de que também ele está a ser vítima de uma tentativa de sedução e aprisionamento, parte. Dido, pelo contrário, não consegue resistir às investidas do Troiano:

Je vous ai accueilli puis retenu en mon palais. Étiez-vous mon invité ou mon prisonnier? Au moment où vous avez perçu cette ambiguïté, vous avez décidé de partir. Quant à vous, Énée, vous mavez emmêlée, emprisonnée dans le filet de votre brillant discours et le piège de votre belle apparence. (p. 62)

Quando relembra a união na caverna, ao contrário das versóes de Virgílio e também, em certa medida, de Ovídio, fá-lo sem ambiguidades nem omissóes ${ }^{4}$. $\mathrm{Na}$ verdade, dominado pelo carácter selvagem da tempestade, Eneias cedeu à fraqueza, à tentação, perdeu o domínio de si próprio e rendeu-se à paixão e à irracionalidade (p. 64). Mas, pouco tempo depois, recuperou o autocontrolo e voltou a ser Eneias:

Après cette union folle et éphémère, comme infligée par les dieux, vous vous êtes repris bien vite, vous avez essuyé votre front en regardant vers le lointain, vous avez lissé vos vêtements et votre chevelure d'une main encore agitée et vous vous êtes dit, vous détournant de moi, que ce n'était pas vous, homme raisonnable, qui vous étiez uni à moi dans la grotte mais que c'était l'orage, l'orage en vous. (p. 64)

${ }^{4}$ Ainda que Ovídio refira o entendimento que Dido tem da natureza da sua união com Eneias, em nenhuma das obras do autor se descreve o que, efectivamente, aconteceu na gruta.

5 Como em Ovídio, Ep. 7.93-6, Dido parece reconhecer o carácter anormal do momento em que ambos se uniram na gruta, como se tivesse sido maquinado pelos deuses. 
A reacção do Troiano à união é, assim, uma reacção que é recorrente: a fuga ao confronto ${ }^{6}$. Eneias tem pressa em negar, em esquecer o que aconteceu. Por isso, limpa o suor e ajusta a roupa amarrotada - a preocupação pela higiene e pela boa apresentação é uma característica típica do herói. Dido, pelo contrário, continuará a recordar:

Moi je n'ai cessé, du temps que je vivais à Carthage, de penser à elle, de l'embellir aussi: à une reine ne sied que la beauté des choses, même si c'est une beauté rêvée. (p. 65)

O contraste de valores é explorado à saciedade. Eneias esquece, porque não é capaz de assumir responsabilidades, porque se recusa a enfrentar sentimentos. Dido, pelo contrário, não só recorda o que aconteceu, como reinventa as lembranças, tornando-as mais sublimes. A necessidade de ornamentar os acontecimentos obedece a um gosto pela beleza que é característico de Dido. É o encanto das palavras de Eneias que a cativam, mas apenas enquanto não percebe que são uma mentira. Iludida pela beleza falseada de um homem que não existe, permite-se amá-lo com toda a força do seu coração, entregando-se cegamente à ilusão de que Eneias seria o homem por quem, quimericamente, esperou durante toda a vida, o homem que procurou em todos os outros homens e por quem seria capaz de tudo. A concessáo que o amor inspira leva-a à abnegação total. É o que diz a Ana, no tom de confidência que caracteriza a relação entre as irmãs:

Laisse-moi, ma soeur, laisse-moi rêver car alors je me sens lumineuse. Pour lui, j'aurais étendu le domaine de mes songes et l'y aurais invité. Pour lui j'aurais bâti cent palais, plus riches que celui-ci, j'aurais planté des arbres aux senteurs rares. Pour lui j'aurais extrait de la terre, de la mer, tous les métaux précieux, les pierreries, les démons enfermés. (p. 41)

A beleza equivale ao desejo de atingir a plenitude, o amor, e esta busca é representada pelo almejo de alcançar um peixe dourado, símbolo da luz e do amor. O peixe dourado é, todavia, inalcançável (pp. 40-1) e simboliza o homem com que Dido sonha mas que é inacessível porque é uma ilusão, só existe nos

${ }^{6}$ De acordo com Dido, a coragem na guerra compensa, em Eneias, a cobardia perante a mulher, num processo de exclusão em que os assuntos divinos anulam as necessidades individuais (p. 43). 
sonhos da rainha. Quando se apercebe da verdade, resolve, ainda assim, morrer pela beleza de um sentimento que só existe nela (p. 56). Reconhecendo a transcendência do seu amor, Dido compreende a impossibilidade de Eneias (ou de outro homem qualquer) corresponder satisfatoriamente a este sentimento:

Il y a des plaintes, des ferveurs si admirables, des amours si hautes, si puissantes, qu'elles ne peuvent recevoir de réponse: de fait elles ne sont pas des demandes, des ordres ni des implorations ("aimez-moi" ou "maimez-vous?") mais des affirmations royales, fastueuses, des certitudes et des jubilations: "je vous aime quoi que vous fassiez, et même quel que vous soyez; j'en vis, j'en suis heureuse, j'en chante..." Ces plaintes d'amour, comme les fermmes qui les envoient, ne demandent rien car elles ont tout déjà. Et voici ce qu'elles disent: "Je vous aime, cela me comble, peu importe que vous maimez ou non." Moi j'ajoute: "Je vous aime, et la façon dont je vous aime est la façon même dont vous m'aimez. Vous n’y pouvez rien, cet amour-là vous échappe, cet amour dont vous m'aimez." (p. 52)

O amor de Dido é absoluto, é sublime. É um sentimento narcísico que não tem necessidade de ser correspondido. Não é uma relação recíproca que implica a resposta do outro, porque náo é delimitado por contingências. São irrelevantes os sentimentos de Eneias pela rainha, porque o amor que ela sente é autosuficiente. Dido pertence a uma espécie de seres que transcendem os limites, ao contrário de Eneias, que vive limitado pelo medo ou pelo dever:

J'aimerais apparaître comme une sublime perdante, comme une éblouissante victime. Ma mort ne se veut ni chantage ni surenchère, c'est une affirmation soutenue: je vous ai aimé, je sais maintenant qui vous êtes, je connais mes mirages, mon aveuglement. Mais malgré tout, pour cet amour de méprise je me tuerai. (p. 56)

Amargamente consciente das diferenças irreconciliáveis entre ambos, Dido prefere morrer heroicamente por um homem que não merece nem a sua morte nem o seu amor. Mas ainda assim, imolando-se por esse homem vil, justifica a força do sentimento que a invade. Não morre por Eneias, mas pelo amor e o seu sacrifício é uma vaidade obstinada pelo desejo de dar beleza a esse amor.

Uma personagem com a dimensão da rainha só poderia morrer, ou na relação amorosa, ou morrer orgulhosamente por 
um homem que não merece nem entende a sua morte:

(...) me tuer non par déception mais par une fierté d'âme, une élégance de vivre qui poussent à offrir un amour extrême à une pauvre figure, à un homme dérisoire. (p. 21)

Ainda que Dido se sacrifique na pira, tem consciência de que o faz por orgulho, pelo apreço de actos sublimes e belos.

Recusando, simultaneamente, a violência da personagem virgiliana e a passividade que exprime em Ovídio, em Les Reines Noires, a vingança da rainha recairá apenas sobre Eneias. Não será, no entanto, um acto de violência. Não porque Dido não tivesse poder para o impedir de partir ou para o massacrar (p. 57). Pelo contrário, poderia ter obrigado Eneias a permanecer em Cartago, pela força ou pela sedução. Se Eneias parte, é porque ela o deixa partir, porque o liberta dos grilhóes do seu amor. A sua vingança não será também uma maldição. Será apenas a certeza de ter deixado partir um ser morto, sem essência, incapaz de amar:

Je sais qu'après moi, Énée, vous n'aurez pas d'autre passion. Je suis la dernière femme, l'ultime passion. Voilà pourquoi je me sens si "veuve", comme "embaumeuse": parce qu'après moi le monde est enterré, vous mort, et tant d'autres femmes possibles, éliminées. (p. 26)

Sem ódio nem execraçóes, a rainha não guarda rancores, aproximando-se, deste modo, da abnegação da personagem ovidiana. Não é necessário amaldiçoar Eneias porque o herói que parte já náoé o mesmo que chegou a Cartago, o homem encantador, iluminado pelos poderes de Vénus. Naquele momento, Eneias era belo porque Dido o amava. Era o amor desta que lhe dava beleza (p. 63). Ao partir, Eneias renunciou a esse amor. O homem que a rainha amava náo existe. Por este motivo, a raiva e o desejo de vingança são irrelevantes.

Não é Eneias que abandona Dido. É Dido quem renuncia a Eneias, por este ser uma pessoa vazia, sem sentido, um homem que náo está à altura da rainha. É a desilusão de reconhecer este engano que a leva ao suicídio. Porque não é Eneias quem Dido ama. Dido ama o amor e esse ficou com ela em Cartago:

L'amour est ici, vous n'êtes pas cet amour. Vous laissant partir, je vous en délivre, comme je vous délivre de moi: vous neêtes pas assez 
fort ni vivant pour l'épreuve. (...) Le Minotaure aussi se mérite. L'épreuve signifie déjà l'élection. Vous croyez me quitter; c'est moi qui vous laisse partir et vous tiens quitte. Nulle dette envers moi, nul geste de ma part pour vous retenir. (p. 57)

O desinteresse que manifesta por Eneias contrasta com o ódio da versão épica e com a dor e o lamento da versão ovidiana. $\mathrm{Na}$ obra de Kelen, Dido mostra-se imune a estes sentimentos, porque está num outro nível, é superior a Eneias e, por este motivo, vinganças, ódios e queixumes não têm qualquer sentido. Dido tem uma outra natureza, faz parte de uma espécie de seres que, como os astros, vivem em plenitude e, por esta razão, não admitem dúvidas ou hesitaçóes. Deste modo, aproxima-se mais da personagem de Dido and Aeneas de Purcell, quando esta afasta Eneias por este ter pensado partir:

For 'tis enough, what'er you now decree,

That you had once a thought of leaving me. (Acto III)

A indiferença que sente perante este homem dá lugar ao contentamento de imaginar que, um dia, Eneias há-de interrogarse sobre a validade da sua acção. $\mathrm{O}$ encontro com Dido será um dia parte do discurso que o herói inventa para encontrar para si próprio uma existência. Numa conversa de homens, em que cada um enumera as suas aventuras, numa taberna, com um copo à sua frente, também ele, um dia, recordará com saudade a rainha:

(...) vous savez, elle s'appellait Didon. Elle n'a même pas pleuré. J'ai embarqué un soir, vivement (...) Vous comprenez, l'honneur... jeétais attendu... oui j'ai failli l'aimer, oui, dès le premier soir. (...) entre ses bras, entre ses cuisses, je ne savais plus rien de la patrie, de mon nom, de mon père, des oracles, de la mission ni des vaisseaux. (...) Dieu que je la désirais! je l'ai su au premier regard. J'avais peur de devenir fou, devenir comme elle cendres et fumée... (pp. 32-3)

Confrontada com o reconhecimento da natureza divergente e incompatível que caracteriza cada um deles e da fatalidade do seu destino, perpetuamente condenado ao desencontro, Dido decide morrer. Não por tristeza por Eneias ter partido, mas para se impedir a si própria de amar um outro e de, mais uma vez, ser abandonada, numa tentativa perene de estabelecer contacto com o outro, sempre em fuga, assustado pelo poder do amor da 
rainha. Dido suicida-se por cansaço, pelo desejo de pôr fim a uma busca que reconhece inglória (pp. 72ss.):

C'est seulement avec Énée que j'ai compris mon malheur: je croyais attendre un homme, en fait j'attendais l'amour. Et comme chaque homme suscitait chez moi ce fleuve immense d'amour, je confondais l'homme et l'amour, la source et le champ arrosé, l'homme aimé avec l'homme qui ềt pu m'aimer, qui ềt été l'amour. Or cet homme-là est, sur terre, introuvable. (pp. 73-4)

Por esta razão, Dido sente-se viúva, não de Siqueu ou de Eneias, mas de um homem que nunca conheceu e por quem esperava ( $\mathrm{p}$. 26). A viuvez de Dido é uma viuvez de nostalgia, ao contrário da viuvez culpada de Eneias. Foi o Troiano quem, por indiferença ou esquecimento, matou Creúsa (p. 44). O tom incriminatório que transparece das palavras da rainha quando analisa a narrativa de Eneias retoma a ironia da epístola ovidiana:

Vous fûtes un bon fils, sauvant votre père Anchise des flammes de Troie, un bon père, protégeant Ascagne, et un bon patriote; un bon mari, je ne sais: vous avez laissé dans le brasier de Troie votre épouse Créüse sans grande hésitation... (p. 18)

Pelas reticências, pela insinuação que faz, situa-se na esteira de Ovídio. Em Les Reines Noires, Dido compreende a relação entre o seu destino e o de Creúsa, que entende como um aviso:

Vous êtes toujours si pressé de partir, de quitter une femme. Votre épouse Créüse, cernée par l'incendie de Troie et que vous laissez là, sans vous en apercevoir, sans vous retourner, préfgure mon destin sur les rives de Carthage. Vous fuyez le feu de l'amour, la brûlure de l'étreinte, la lumière de l'initiation venue de femme. (pp. 43)

Lemos nas entrelinhas a presença da Dido ovidiana. Na lucidez com que analisa a situaçáo, na perspicácia e profundidade com que interpreta a "alma" de Eneias, Dido revela um conhecimento da situação em que se encontra que a afasta da fati nescia Dido, da "Dido desconhecedora do destino", de Virgílio (A. 1, 299). No entanto, à imagem da versão épica, revela uma natureza sublime que transcende a fragilidade da existência mortal e se aproxima do excesso, primeiro revelado no amor, depois no ódio, da personagem virgiliana. 
A força do amor de Dido é uma constante na sua caracterização, desde Virgílio. A força que esse amor assume na obra de Kelen transforma-o, todavia, numa realidade assustadora, porque sem limites. O sentimento que Dido nutre não é por Eneias ou por outro homem qualquer. É o amor do amor. Mas é também a busca da morte, a desistência da procura, que corresponde a uma transição para o absoluto. Também por isso amou Eneias, porque sabia que morreria depois de se encontrar com ele:

Mes baisers d'amante cachaient à peine une reconnaissance éperdue, la jubilation déjà de rencontrer ma mort et de l'aimer, oui, l'aimer plus que tout, plus que cette main qui l'octroie. (...) Je me sentais amante de la mort plus que de vous. J'étais si exténuée, je voulais le repos silencieux loin des corps fiévreux. (...) Didon vous aura appris que plus que la terre on peut souhaiter habiter le monde dit infernal et qu'on peut aimer et implorer, plus que l'amour, la mort infiniment musicale. (pp. 49-50)

A morte é, assim, o descanso final, a quietude de um coração impetuoso, cansado de procurar. É um fim que Dido deseja e, por esse motivo, é com calma que enfrenta a morte e que, definitivamente, se separa do Troiano:

Calme je monterai sur le bûcher. Calme comme la grande douleur, comme le plus haut amour (et vous ne verrez jamais mes yeux à l'instant suprême). De moi vous ne retiendrez que le silence: silence de ceux qui savent, de ceux qui aiment, de ceux qui ont épousé le Feu. (p. 58)

Ao alcançar a paz de espírito, Dido cumpre a sua vingança: o silêncio, a indiferença perante Eneias. Este, pelo contrário, continuará, perturbado, a sua busca quimérica:

Soyez délivré à votre tour, Énée, et continuez de croire aux fondations des cités humaines, aux navires amarrés, aux femmes qu'on abandonne et à votre mission. (p. 50)

A calma que Dido alcança na morte contrasta com a perturbação do Troiano, errante e cheio de dúvidas acerca do seu passado e do seu futuro. No último capítulo, quando se encontram nos Infernos, o contraste de valores mantém-se. Dido está em paz, desfruta da serenidade que alcançam os que, enquanto vivos, deram tudo: 
Elle est morte - c'est-à-dire elle a quitté son corps mortel - elle est en paix. Lui entame sa course errante, sa course effrénée de mortel aveugle. Il commence seulement à sinterroger. Elle sait, elle est apaisée. Lui est assailli de doutes: si le "bonheur" était là, à Carthage? si la Ville à fonder était, déjà prêt, le Palais de la Reine? si son oeuvre de fondateur de race était d'unir son sang à celui de l'Étrangère? Trop tard. (p. 76)

As diferenças irreconciliáveis que os afastaram em Cartago separam-nos também nos Infernos. Mantém-se em Dido a calma da sua morte e a indiferença por aquele homem:

Didon n'accorde aucun regard, aucune parole à Énée. Ne lui a-t-elle pas déjà tout donné? Maintenant qu'elle est ici, délivrée, elle le renvoie dans la cohorte indifférenciée des ombres errantes: non pas celles qui, fluides, habitent les Enfers sans douleur, sans mémoire, mais ces fantômes d'hommes qui ne vivent pas, qui n'ont jamais aimé ou qui n'osèrent pas. (p. 75)

Como Orfeu, Eneias vem aos Infernos em busca do amor perdido, em busca da mulher que era a sua última oportunidade de alcançar o amor. Mas, à imagem de Eurídice, Dido pertence já a um outro mundo, está numa outra dimensão, e não há regresso possível. Assim, como Orfeu e Eurídice, Eneias e Dido estão irremediavelmente separados, não só por um estar vivo e o outro morto, mas por pertencerem a mundos diferentes. Por este motivo, no limiar dos Infernos, ecoa aos ouvidos de Eneias "Souviens-toi d'Orphée..." (p. 77).

A obra de Kelen dá continuidade ao confronto estabelecido entre Virgílio e Ovídio, mantendo a sublimidade que o primeiro imprimiu em Dido, mas reduzindo a ambiguidade da personagem, no seguimento do segundo. $O$ resultado da reeleboração das fontes é uma reflexão caracterizada por um lirismo notável que confere à personagem uma lucidez semelhante à que define Dido em Ovídio. Incorpora, todavia, na caracterização da rainha elementos contemporâneos, como a oposição entre os sexos, que lhe garantem uma profundidade emocional superior às primeiras versôes. Assim inserida na problemática da relação dos sexos e numa perspectiva feminista, a relação entre Dido e Eneias torna-se um símbolo das diferenças e incompatibilidades dos seres, retomando, deste modo, o polémico abandono de que Dido foi vítima. 


\section{Conclusāo}

A história de Dido é uma história de relaçóes humanas e de opçóes. Adificuldade de definir cabal e univocamente a personagem - ou, melhor, as personagens - advém da impossibilidade de interpretar e avaliar a natureza humana. Cada um dos autores que, ao longo dos séculos, se deixou cativar por Dido ou por Elissa, imprimiu nela a sua mundividência, realçando um ou outro traço da personagem em detrimento de outros e aproximando-se mais de uma versão do que de outras. Este processo inesgotável de reelaboraçáo só é possível porque, baseando-se na tradição historiográfica, Virgílio inventou uma personagem sem contornos humanamente delimitados. A multiplicidade da criação virgiliana favorece a variedade de abordagens que se sucederam, talvez porque o talento de Virgílio resida também na forma como soube delinear a complexidade da psyche humana.

Ovídio escolheu, no manancial de interpretaçóes oferecido por Virgílio, a caracterização que mais the agradava e que soube explorar e enriquecer com mestria. Transformando Dido numa mulher de carne e osso, definiu-a como uma figura feminina de natureza frágil, abandonada de forma infame por Eneias.

Sílio Itálico, pelo contrário, optou em parte pela força irracional e destrutiva da personagem, não sendo, no entanto, capaz de resistir à humanidade e simpatia que Ovídio nela realçara.

Também o autor anónimo da Epistula Didonis ad Aeneam procurou o equilíbrio das versóes anteriores, concedendo a Dido a fragilidade emocional e o amor abnegado ovidianos, sem deixar de referir os traços virgilianos da vingança e da violência.

As implicaçôes morais da versão épica provocam a reacção de alguns autores que recuperam a perspectiva presente na obra fragmentária de Timeu de Tauroménio. Assim, contrapóe-se à mestria de Virgílio a denúncia da falácia da poesia e a defesa do carácter incensurável da rainha, que se manteve perseverante na fidelidade a Siqueu.

As versões mais modernas do mito mantêm esta diversidade, recolhendo o manancial de interpretaçóes veiculadas pelas versóes anteriores. 
A impossibilidade da união entre Dido e Eneias ou entre Dido e Jarbas é comum à maioria das versóes. Por um motivo ou por outro, esta relação está condenada ao fracasso: porque Dido tenciona manter-se fiel a Siqueu, porque Eneias tem de seguir o seu destino, porque Eneias e Dido têm naturezas diversas... O desencontro amoroso caracteriza a história de Dido. Talvez este facto explique o fascínio que rodeia a personagem e a simpatia que tem suscitado: é porque o desencontro simboliza a inevitabilidade das escolhas difíceis. Nem sempre o dever e o prazer se conjugam. A morte da rainha é também prova de que as opçóes de cada indivíduo se reflectem no outro, que facilmente se torna vítima dessas opçóes, porque nenhum homem é uma ilha. 


\section{Bibliografia}

\section{Textos E Traduçóes.}

Aubreton, R. (1980), Anthologie Grecque, 2ème partie, Anthologie de Planude, Paris, "Les Belles Lettres".

Austin, R. G. (1982), P. Vergili Maronis Aeneidos Liber Quartus, Oxford, Clarendon Press.

(1986), P. Vergili Maronis Aeneidos Liber Sextus, Oxford, Clarendon Press.

Bode, G. H. (1996), Scriptores Rerum Mythicarum Latini Tres Romae Nuper Reperti, Hildesheim-Zürich-New York, Georg Olms Verlag.

Bornecque, H. (1991), Ovide. Héroïdes, Paris, "Les Belles Lettres".

Descamps, H. et al. (1846), Oeuvres de Macrobe, Paris, C. L. F. Panckoucke Éditeur.

Duff, J. D. (1996r), Silius Italicus Punica, 2 vol., Cambridge \& London, Harvard University Press.

Green, R. P. H. (1991), The Works of Ausonius, Oxford, Clarendon Press.

Јакову, F. (1950), Die Fragmente der Griechischen Historiker, Leiden, E. J. Brill.

Kerr, W. C. (19927), Tertullian Apology \& De Spectaculis, Harvard University Press.

Knox, P. E. (1995), Ovid. Heroides. Select Epistles, Cambridge University Press.

Menghi, M. (1995), Tertulliano. De Spectaculis. Ad Martyras, Milano, Arnoldo Mondadori Editore.

Morel, W., K. BüCHner, et al. (1995), Fragmenta poetarum Latinorum epicorum et lyricorum praeter Ennium et Lucilium, Stutgardiae, B.G. Teubner. 
Mynors R. A. B. (1972), P. Vergili Maronis Opera: Aeneis, Oxford University Press.

Riese, A. (1964), Anthologia Latina, Amsterdam, Verlag Adolf M. Hakker.

Shackleton Bailey, D. (1982), Carmina in Codicibus Scripta, 1: Libri Salmasiani aliorumque carmina, Stuttgardiae.

Solimano, G. (1988), Epistula Didonis ad Aeneam, Genova, Dipartimento di Archeologia, Filologia Classica e loro Tradizioni.

SeEl, O. (ed.) (1972), M. Iuniani Iustini Epitoma Historicarum Philippicarum Pompei Trogi, Stutgardiae in aedibus B. G. Teubneri.

Watts, W. (1988), St. Augustine. The Confessions, Harvard University Press.

\section{Estudos}

Ahr, F., Davis. M. A. \& Pomeroy, A. (1986), "Silius Italicus", ANRWII. 32.4, pp. 2492-2561.

André, C. A. (2006), Caminhos do Amor em Roma, Lisboa, Cotovia.

Aziza, C. (1990), "Les visages de Didon dans la fiction contemporaine" in MARTIN (1990), pp. 157-62.

Baccar, A. (1990), "Survie d' Elissa-Didon dans la Tunisie Contemporaine" in MARTin (1990), pp. 241-9.

Bardon, H. \& Verdière, R. (edd.) (1971), Vergiliana: Recherches Sur Virgile, Leiden, E. J. Brill.

Beye, C. R. (1993), Ancient Epic Poetry: Homer, Apollonius, Virgil, Ithaca \& London, Cornell University Press.

Boyd, B. W. (2002), Brill's Companion to Ovid, Leiden-BostonKoln, Brill.

Boyle, A. J. (ed.) (1993), Roman Epic, London \& New York, Routledge. 
Bono, P. \& Tessitore, M. V. (1998), Il Mito di Didone: Avventure di una regina tra secoli e culture, Milano, Edizioni Bruno Mondadori.

Braund, S. M. \& Gill, C. (edd.) (1997), The Passions in Roman Thought and Literature, Cambridge University Press.

Briggs, W. W. (1981), "Virgil and the Hellenistic Epic", $A N R W$ II. 31.2, pp. 948-983.

Burden, M. (ed.) (1998), A Woman Scorn'd: Responses to the Dido Myth, London, Faber and Faber.

CaIrns, F. (1989), Virgil's Augustan Epic, Cambridge University Press.

Camps, W. A. $\left(1992^{8}\right)$, An Introduction to Virgil's Aeneid, Oxford University Press.

Chevalier, R. (ed.) (1978), Présence de Virgile, Paris, "Les Belles Lettres".

(ed.) (1982), Colloque Présence d'Ovide, Paris, "Les Belles Lettres".

Conte, G. B. (1986), The Rhetoric of Imitation: Genre and Poetic Memory in Virgil and Other Latin Poets, Ithaca \& London, Cornell University Press.

Cooper, K. (1996), The Virgin and the Bride: Idealized Womanhood in Late Antiquity, Harvard University Press.

Courcelle, P. \& Courcelle, J. (1985), Lecteurs Pä̈ens et Lecteurs Chrétiens de l'Énéide, Paris, Diffusion de Boccard.

Davidson, J. (1998), “Domesticating Dido” in Burden (1998), pp. $65-88$.

Desmond, M. (1994), Reading Dido: Gender, Textuality, and the Medieval Aeneid, Minneapolis-London, University of Minnesota Press.

Ducos, M. (1990), "Passion et politique dans les tragédies de Didon” in MarTin (1990), pp. 97-107.

Ernout, A. \& Meillet, A. (1994 ), Dictionnaire Étymologique de la Langue Latine, Paris, Klincksieck. 
FArron, S. (1980), "The Aeneas-Dido episode as an attack on Aeneas' mission and Rome", Greece \& Rome 27, pp. 3447.

(1993) Vergil's Aeneid: A Poem of Grief \& Love, Leiden-London-Köln, E. J. Brill.

Foley, H. P. (ed.) (19924), Reflections of Women in Antiquity, New York, Gordon and Breach Science Publishers.

Foley, J. M. (2005), A Companion to Ancient Epic, Malden, MA, Blackwell Pub.

Foucher, M. D. L. (1978), "Les Phéniciens à Carthage ou la geste d'Élissa" in Chevalier (1978), pp. 1-15.

Fulkerson, L. (2005), The Ovidian Heroine as Author: reading, writing, and community in the Heroides, Cambridge \& New York, Cambridge University Press.

Galinsky, K. (1996), Augustan Culture: An Interpretive Introduction, Princeton, Princeton University Press.

(ed.) (2005), The Cambridge Companion to the Age of Augustus, Cambridge University Press.

Gharbi, B. (1990), “Infelix Dido: la thématique de Didon” in MARTIN (1990), pp. 11-22.

Gill, C. (1997), "Passion as madness in Roman poetry" in BRAUND \& Gill (1997), pp. 213-41.

Grimal, P. (1990), "Didon Tragique" in Martin (1990), pp. 5-10.

(1992), Dicionário da Mitologia Grega e Romana, (coordenação da tradução de Victor Jabouille) Lisboa, Difel.

(1992a), "Les amours de Didon ou les limites de la liberté” in Wilhelm \& Jones (1992), pp. 51-63.

Hano, M. (1990), "Inventaire des peintures consacrées à l'épisode de Didon et d' Énée” in Martin (1990), pp. XXVIIXXXI.

(1990a), "L'épisode d'Énée et Didon vu par les peintres" in MarTin (1990), pp. 275-288. 
Hardie, P. (1993), The Epic Successors of Virgil: A Study in the Dynamics of a Tradition, Cambridge University Press. pp. 312-26.

(1997), "Virgil and tragedy" in Martindale (1997),

Hardie, P. et al. (2002), The Cambridge Companion to Ovid, Cambridge, Cambridge University Press.

Harrison, E. L. (1988), "Why did Venus wear boots? Some reflections on Aeneid I.314f." in Robertson (ed.), pp. $197-214$.

Harrison, S. J. (ed.) (1990), Oxford Readings in Vergil's Aeneid, Oxford-New York, Oxford University Press.

Herescu, N. I. (ed.) (1958), Ovidiana. Recherches sur Ovide, Paris, "Les Belles Lettres".

Hersh kowitz, D. (1998), The Madness of Epic: Reading Insanity from Homer to Statius, Oxford, Clarendon Press.

Hexter, R. \& Selden, D. (edd.) (1992), Innovations of Antiquity, New York \& London, Routledge.

- (1992A), "Sidonian Dido" in Hexter \& Selden (edd.) (1992), pp. 332-84.

Horsfall, N. (1990), "Dido in the light of history " in Harrison (ed.) (1990), pp. 127-144.

(1995), A Companion to the Study of Vergil, Leiden $\&$ New York, E. J. Brill.

Jakobson, H. (1974), Ovid's Heroides, Princeton, Princeton University Press.

Jenkyns, R. (1996), "Dido and Creusa" in Classical Epic: Homer and Virgil, London, Bristol Classical Press, pp. 57-62.

Johnson, W. R. (1976), Darkness Visible: A Study of Vergil's Aeneid, Berkeley, University of California Press.

Jolivet, J.-C. (2001), Allusion et fiction épistolaire dans les Héroides : recherches sur l'intertextualité ovidienne, Rome, Ecole Française de Rome. 
Keith, A. M. (2000), Engendering Rome: Women in Latin Epic, Cambridge University Press.

Khan, H. A. (1968), "Dido and the sword of Aeneas", Classical Philology 63, pp. 283-285.

Knauer, G. N. (1981), "Vergil and Homer", $A N R W$ II. 31.2, pp. 870-918.

(1990), "Vergil's Aeneid and Homer" in Harrison (1990), pp. 390-412.

Lilja, S. (1978), The Roman Elegists' Attitude to Women, New York, Garland Publishing, Inc..

Lindheim, S. H. (2003), Mail and Female: Epistolary Narrative and Desire in Ovid's Heroides, Madison, Wis., University of Wisconsin Press.

Lipking, L. (1988), Abandoned Women and Poetic Tradition, Chicago \& London, The University of Chicago Press.

Lyne, R. O. A. M. (1992), Further Voices in Virgil's Aeneid, Oxford, Clarendon Press.

Martin, R. (ed.) (1990), Enée et Didon: Naissance, fonctionnement et survie d'un myhte, Paris, Éditions du CNRS.

Martindale, C. (ed.) (1997), The Cambridge Companion to Virgil, Cambridge University Press.

McKleish, K. (1972), "Dido, Aeneas, and the concept of pietas", Greece \& Rome, s. s. 19.2 (1972), pp. 127-135.

Medeiros, W., André, C. A. \& Pereira, V. S. (1992), A Eneida em Contraluz, Coimbra, Instituto de Estudos Clássicos.

Moles, J. L. (1984), “Aristotle and Dido's hamartia”, Greece and Rome 31, pp. 48-54.

Morier, H. (19894), Dictionnaire de Poétique et de Rhétorique, Paris, PUF.

Moskalew, W. (1982), Formular Language and Poetic Design in the Aeneid, Leiden, E. J. Brill.

Moya del Baño, F. (1969), Estudio Mitográfico de las Heroidas de Ovidio, Publicaciones de la Universidad de Murcia. 
Nugent, S. G. (1999), "The women of the Aeneid: vanishing bodies, lingering voices" in Perkell (1999), pp. 251-70.

Nutall, A. D. (1998), "Inconstant Dido" in Burden (1998), pp. 89-104.

O' Hara, J. J. (1990), Death and Optimistic Prophecy in Vergil's Aeneid, Princeton University Press.

Oliensis, E. (1997), "Sons and lovers. Sexuality and gender in Virgil's poetry” in Martindale (1997), pp. 294-311.

Отіs, В. (1963), Virgil: A Study in Civilized Poetry, Oxford.

Pavlock, B. (1990), Eros, Imitation, and the Epic Tradition, Ithaca $\&$ London, Cornell University Press.

Perkell, C. G. (19924), "On Creusa, Dido, and the quality of victory in Virgil’ s Aeneid” in Foley (ed.) (19924), pp. 35577.

(ed.) (1999), Reading Vergil's Aeneid: An Interpretive Guide, Norman, University of Oklahoma Press.

Pigon, J. (1991), "Dido, Diana and Penthesilea: observations on the Queen's first appearance in the Aeneid", Eos 79 (1991), pp. 45-53.

Pimentel, M. C. (1990), "Eneias ou o homem em busca de si mesmo" in Estudos sobre a Eneida, Lisboa, Publicaçóes da Revista Clássica, pp. 123-182.

Poвjoy, M. (1998), "Dido on the tragic stage: an invitation to the theatre of Carthage" in BURDEN (1998), pp. 41-64.

Poinsotte, J.-M. (1990), "L'image de Didon dans l'Antiquité tardive" in Martin (1990), pp. 43-54.

Pöschl, V. (1962), The Art of Vergil: Image and Symbol in the Aeneid, (trad. de Gerda Seligson), Ann Arbor, Michigan.

(1978), "Virgile et la tragédie" in Chevalier (ed.) (1978), pp. 73-79.

Powell, A. (1997), Roman Poetry \& Propaganda in the Age of Augustus, London, Bristol Classical Press. 
- $\left(1997^{\mathrm{r}} \mathrm{A}\right)$, "The Aeneid and the embarrassments of Augustus" in Powell (ed.) (1997r), pp. 141-174.

Putnam, M. C. J. (1995), Virgil's Aeneid: Interpretation and Influence, Chapel Hill \& London, The University of North Carolina Press.

(1998), Virgil's Epic Designs: Ekphrasis in the Aeneid, New Haven \& London, Yale University Press.

Quint, D. (1993), Epic and Empire: Politics and Generic Form from Virgil to Milton, Princeton, Princeton University Press.

L. D. Reynolds (ed.) (1998r), Texts and Transmission: A Survey of the Latin Classics, Oxford, Clarendon Press.

Robertson, F. (ed.), Meminisse Iuvabit: Selections from the Proceedings of the Virgil Society, Bristol Classical Press.

Rodrigues, M. S. (1990), "O episódio de Dido na Eneida", in Estudos sobre a Eneida, Lisboa, Publicaçóes da Revista Clássica, pp. 1-19.

Rudd, N. (1990), "Dido's culpa”, in Harrison (ed.) (1990), pp. 145-166.

Sавот, A. F. (1981), "Les Heroïdes d'Ovide: préciosité, rhétorique et poésie", $A N R W$ II. 31. 4, pp. 2552-2636.

Smith, R. A. (1997), Poetic Allusion and Poetic Embrace in Ovid and Virgil, Ann Arbor, The University of Michigan Press.

Sparrow, J. (1973), Dido v. Aeneas: the case for the defence, Berkshire, The Abbey Press.

Spence, S. (1999), "Varium et mutabile: voices of authority in Aeneid 4" in Perkell (1999), pp. 80-95.

Stahl, H.-P. (1998), Vergil's Aeneid: Augustan Epic and Political Context, London, Duckworth.

Stroppini de Focara (1990), "Didon amante et reine" in Martin (1990), pp. 23-32.

Sullivan, J. P. (1992), "Dido and the representation of women in Vergil's Aeneid” in Wilhelm \& Jones (1992), pp. 64-73. 
Suzuki, M. (1989), Metamorphoses of Helen: Authority, Difference, and the Epic, Ithaca \& London, Cornell University Press.

Tarrant, R. J. (1998), "Anthologia Latina”, in Reynolds (ed.) (1998), pp. 9-13.

Tibilettr, C. (1981), "La Donna in Tertulliano", in Misoginia e Maschilismo in Grecia e in Roma, Genova, Istituto di Filologi Classica e Medievale, pp. 69-95.

Treggiari, S. (1993), Roman Marriage: Iusti Coniuges From the Time of Cicero to the Time of Ulpian, Oxford, Clarendon Press.

Tupet, A.-M. (1971), "Dido magicienne”, Révue des Études Latins 48 (1971), pp. 229-258.

Verducci, F. (1985), Ovid's Toyshop of the Heart: Epistulae Heroidum, Princeton, Princeton University Press.

von Albrecht, M. (1999), Roman Epic: An Interpretive Introduction, Leiden-Boston-Köln, Brill.

Veyne, P. (1983), L'Élegie Érotique Romaine, l'amour, la poésie et l'Occident, Paris, Éditions du Seuil.

Watkins, J. (1995), The Specter of Dido: Spenser and Virgilian Epic, New Haven \& London, Yale University Press.

Whitman, J. (1987), Allegory: The Dynamics of an Ancient and Medieval Technique, Cambridge-Massachusetts, Harvard University Press.

Wilhelm, R. M. \& Jones, H. (edd.) (1992), The Two Worlds of the Poet: New Perspectives on Vergil, Detroit, Wayne State University Press.

Williams, G. (1998), The Nature of Roman Poetry, Oxford University Press.

Williams, R. D. (1971), "Dido's reply to Aeneas (AA. 4, 362-387)" in Bardon \& Verdière (edd.) (1971), pp. 422-428.

Williams, R. D. (1990), “The pictures on Dido' s temple (Aeneid 1, 450-93)" in Harrison (ed.) (1990), pp. 37-45. 
Wilkinson, L. P. (1962), Ovid Surveyed, Cambridge University Press.

Wright, M. R. (1997), "Ferox uirtus: anger in Virgil's Aeneid" in Braund \& Gill (1997), pp. 169-184. 


\section{Volumes publicados na Colecção "Varia" - SÉRIE MoNografiaS}

1. Mariana Montalvão Matias, Paisagens naturais e paisagens da alma no drama senequiano. "Troades" e "Thyestes" (Coimbra, CECH, 2009).

2. João Paulo Barros Almeida, Sentimento e conhecimento na poesia de Camilo Pessanha (Coimbra, CECH, 2009).

3. Cristina Santos Pinheiro, Opercurso de Dido, rainha de Cartago, na Literatura Latina (Coimbra, CECH/CEC, 2010). 
Impressão:

Simões \& Linhares, Lda.

Av. Fernando Namora, n. ${ }^{\circ} 83$ Loja 4 3000 Coimbra 
A Encida de Virgílio apresenta a versão mais célebre e influente da história de Dido, rainha lendária de Cartago que, na epopeia virgiliana, acolhe Eneias, o herói troiano filho de Vénus que viaja em direcção ao Ocidente para fundar uma nova pátria. Autores como Ovídio, Sílio Itálico ou o autor anónimo da Epistula Didonis ad Aeneam, elaboram novas versões que interpretam a complexidade da Dido de Virgílio, complexidade que se baseia nas dificuldades inerentes às relações pessoais. Mulher fatal e esposa traída, símbolo de castidade e heroína feminista, Dido espelha a multiplicidade da natureza humana e a mundividência de cada um dos autores que, ao longo dos séculos, por ela se deixaram cativar. É precisamente a algumas das abordagens literárias mais paradigmáticas da imagem de Dido que se dedica o estudo agora publicado. 